
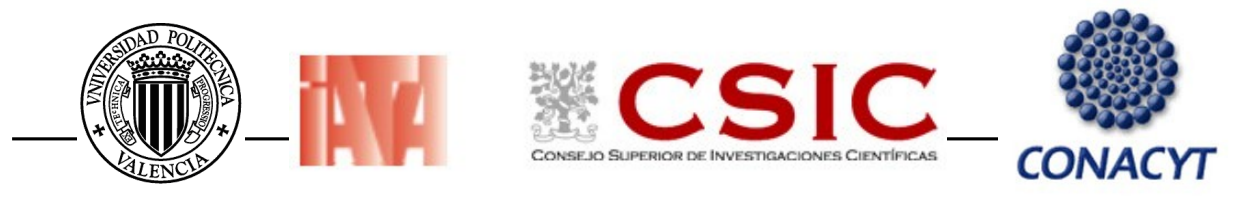

Universidad Politécnica de Valencia

Instituto de Agroquímica y Tecnología de Alimentos

Consejo Nacional de Ciencia y Tecnología, México

\title{
Influencia de la microbiota intestinal en la obesidad
}

TESIS DOCTORAL

\author{
Presentada por: \\ Yolanda Arlette Santacruz López \\ Dirigida por: \\ Yolanda Sanz Herran

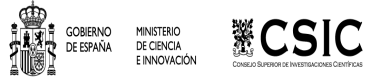 \\ INSTITUTO DE AGROQUÍMICA Y


$\mathrm{D}^{\mathrm{a}}$ Yolanda Sanz Herranz, Investigador científico del Instituto de Agroquímica y Tecnología de Alimentos del Consejo Superior de Investigaciones Científicas,

\section{Certifica:}

Que la tesis Doctoral titulada "Influencia de la microbiota intestinal en la obesidad", de la que es autora la licenciada Yolanda Arlette Santacruz López, ha sido realizada en el Instituto de Agroquímica y Tecnología de los Alimentos (IATA-CSIC) bajo su dirección y que reúne las condiciones necesarias para optar al grado de Doctor por la Universidad Politécnica de Valencia.

Valencia, Julio, 2012

Fdo.: Dra. Yolanda Sanz Herranz 
"La vida es una unión simbiótica y cooperativa que permite triunfar a los que se asocian."

Lynn Margulis

(1938-2011) 


\section{AGRADECIMIENTOS}

Ahora que he culminado mi tesis doctoral, quiero darle un agradecimiento muy especial a todos los mexicanos que pagaron sus impuestos, gracias a ellos, el CONACYT pudo becarme por cinco años para que pudiera aprender y conocer tantas cosas de mi área como de la cultura europea. Gracias a CONACYT por apoyarme en la realización de mi tesis, todo lo aprendido lo pondré en práctica ahora que regrese a México.

Gracias a la Dra. Yolanda Sanz porque sin conocerme, desde un principio me apoyo para poder venir a Valencia. Gracias por todas las enseñanzas profesionales y personales que me diste, has contribuido mucho en mi carrera de la investigación.

No olvidare todas las lecciones que aprendí en el IATA y en especial en el Lab 103 y después el Lab 114. Todas las personas que allí conocí, aportaron algo para que en estos 5 años haya aprendido mucho en el ámbito profesional y personal. Espero nunca olvidar todo lo que viví allí. Me ayudaron para conocerme más. Se que todo lo que aprendí me servirá de mucho y creo que este fue el momento ideal para tomar esas lecciones. Mencionaré a cada persona que contribuyo a ello. El orden será como recuerdo que las conocí y no significa su importancia: Inma, Giada, Ester, Mari Carmen, Amparo, Carmen, Moisés, Onofrio, Marta, Ma. Jesús, Paola, Bea, Ángela, Fernando, Iris, Amparito, Eva, Sabina, Xinxin, Mariam, etc.

A mis hermanos, sobrinas (Amy, Any y Andy), y en especial a mis papás. Gracias por apoyarme desde lejos, por no dejarme regresar a casa cuando sentía que ya no podía más. Mamá muchas gracias por ayudarme siempre en todas mis decisiones. Papá me hubiera gustado que me felicitaras en persona, pero quiero creer que desde donde estés, te sientes satisfecho.

Siempre he pensado que un éxito no se logra por si solo, es el cúmulo de circunstancias y personas específicas que se acoplan para lograr esa meta. En todas las metas que he alcanzado, siempre he tenido a mi lado a muchas personas que me enseñaron y ayudaron demasiado, es por ello que les llamo amigos. Para todos mis amigos son estos agradecimientos. Espero que todos 
ustedes sigan estando conmigo aunque el destino nos lleve a lugares diferentes. Gracias por ayudarme a alcanzar este sueño.

Un gran agradecimiento especial...

A Giada, que comenzó siendo una compañera de lab. y termino siendo mas que una amiga. Gracias por todo lo que me has dado, por todas las risas, lágrimas, gritos, desvelos, horas de trabajo, cervezas, conciertos, viajes y cenas que compartimos. Como olvidar tus cuidados, enseñanzas y consejos, créeme, nunca te podría olvidar. Todo lo que aprendí en estos años de doctorado fue gracias a ti. Hasta en los últimos momentos de la tesis, aunque estabas del otro lado del mundo, me ayudaste muchísimo. Recuerda que siempre correré junto a ti.

A Rous Helen, que hizo que confirmara que el mundo microscópico tiene una gran belleza. Has estado conmigo siempre, no importo que un océano nos separara, siempre has tenido las palabras exactas en el momento indicado, Gracias por no abandonarme y enviarme oraciones siempre que lo necesite. Siempre estaré contigo. ¡Tus calcetines me ayudaron mucho!, Aunque al final se les acabo su efecto.

A Adela que desde un principio me acepto y ayudo a integrarme al mundo de Angresola y Valencia. Gracias por escucharme cuando el trabajo me sobrepasaba. Aunque no entendieras mis experimentos siempre me escuchabas y tratabas de que me sintiera mejor. Me has ayudado mucho en mi estancia en Valencia, estaré toda la vida en deuda contigo. He terminado mi aventura Valenciana pero ahora es el turno de que comiences tu aventura Mexicana.

Al "Dr. Trejo", que vaya a donde vaya deja ver su gran inteligencia emocional. Tengo tantas cosas que agradecerte, que para no errar, solo puedo decir que hiciste que el laboratorio fuera un lugar muy agradable. Después de conocerte el levarse los dientes, tiene otro sentido para mí.

Al Dr. Aurelio López Malo Vigil, que cuando te conocí, no creí todo lo que podrías llegar a influir en mi carrera profesional. Por ti entre al fascinante mundo de los probióticos. Gracias por ser mi profesor, mi director de tesis, y sobretodo mí amigo. Gracias por escucharme a través del teléfono cada vez que sentía que la aventura española acababa conmigo. Has estado siempre que te he necesitado. Mucho de este logro es gracias a ti, Gracias por todo. 


\section{RESUMEN}

La obesidad es el resultado del desequilibrio entre la ingesta y el gasto energético, provocando un aumento en el peso y la grasa corporal, así como mayor predisposición a desarrollar enfermedades crónicas. Se ha observado que en el desarrollo de la obesidad no solo interviene la dieta, sino también factores genéticos, endocrinos, psicológicos y ambientales. En las últimas décadas la microbiota intestinal también se ha incluido entre los factores que pueden tener una influencia clave en la obesidad y el metabolismo. La prevalencia de la obesidad especialmente en niños y adolescentes cada vez es mayor, constituyendo uno de los primeros problemas de salud pública a nivel mundial. Por ello, es necesario seguir avanzando en la identificación de los factores que pueden contribuir a la obesidad y en el desarrollo de estrategias alternativas que permitan disminuir su prevalencia y comorbilidades.

El objetivo global de la tesis ha sido la identificación de los cambios en la composición de la microbiota intestinal asociados a la obesidad y la valoración de la función de componentes específicos de la microbiota en la obesidad y las alteraciones metabólicas e inmunológicas asociadas en un modelo animal

El primer objetivo específico fue determinar la influencia de una intervención para el tratamiento de la obesidad sobre la microbiota intestinal de adolescentes obesos y con sobrepeso. Mediante las técnicas de PCR a tiempo real o cuantitativa (q-PCR) e hibridación in situ con sondas fluorescentes (FISH), se cuantificaron los principales grupos bacterianos del tracto intestinal. 
Los adolescentes que experimentaron mayor perdida de peso, presentaron aumentos de las concentraciones o proporciones relativas de los grupos Bacteroides o Bacteroides - Prevotella y Lactobacillus, así como reducciones del grupo E. rectale - C.coccoides. La microbiota de los adolescentes que experimentaron una pérdida de peso significativa se caracterizó por presentar mayores concentraciones iniciales y finales de los grupos B. fragilis, C. leptum y B. catenulatum y menores de los grupos $C$. coccoides, Lactobacillus, Bifidobacterium, B. breve y B. bifidum, lo que sugiere que la microbiota del individuo puede influir en la eficacia de las intervenciones basadas en cambios en el estilo de vida para tratar la obesidad.

En adolescentes obesos se detectó un aumento de la proporción de $\operatorname{IgA}$ asociada a bacterias intestinales, relacionado con las proporciones de $C$. histolyticum y E. rectale - C. coccoides, que se redujeron tras la intervención para tratar la obesidad, lo que sugiere que algunos componentes de la microbiota posiblemente implicados en la obesidad o sus metabolitos influyen en el sistema inmunitario del hospedador.

La obesidad también se asocia a complicaciones durante el embarazo, incrementando el riesgo de salud del niño al nacer y el de padecer obesidad y otras patologías relacionadas. Por ello se planteó también como objetivo evaluar la composición de la microbiota intestinal de mujeres embarazadas con sobrepeso por qPCR y su relación con parámetros bioquímicos y dietéticos. Las mujeres con sobrepeso presentaron menores concentraciones de los grupos Staphylococcus, Enterobacteriaceae y E. coli, y reducciones en las de los 
géneros Bifidobacterium y Bacteroides. El aumento de E. coli y la reducción de Bifidobacterium spp. y Akkermansia muciniphila también se asoció a la ganancia excesiva de peso durante el embarazo. Además, los aumentos en la concentración de colesterol sérico se relacionaron con aumentos en Staphylococcus spp., los aumentos en el colesterol HDL y reducciones en el colesterol total se relacionaron con aumentos en Bacteroides spp., los aumentos en ácido fólico se relacionaron con aumentos en Bifidobacterium spp., los niveles de ferritina y transferrina reducida mostraron relaciones opuestas con las concentraciones de enterobacterias y Bifidobacterium spp. Por todo ello, se puede afirmar que la microbiota intestinal esta relacionada con el peso corporal, con la ganancia de peso y los parámetros metabólicos durante el embarazo, lo cual puede ser relevante para la salud de la madre y del hijo.

Después de haber estudiado la relación que existe ente la microbiota intestinal y el metabolismo, el siguiente objetivo que se planteó fue estudiar el efecto de la cepa B. pseudocatenulatum CECT 7765 como potencial probiótico en un modelo animal de obesidad. En animales con obesidad inducida con una dieta rica en grasa, se observó que la administración de esta bacteria reducía el colesterol, los triglicéridos, la glucosa, la leptina, la esteatosis hepática y el tamaño de los adipocitos con respecto al grupo obeso no tratado con la cepa. Asimismo, mejoró la función de células inmunocompetentes (macrófagos y células dendríticas) y moduló la composición de la microbiota, reduciendo sus propiedades inflamatorias. Por tanto, esta cepa mejora las alteraciones metabólicas e inmunológicas asociadas a la obesidad inducida por la dieta en un modelo murino. 


\section{RESUM}

L'obesitat és el resultat del desequilibri entre la ingesta i la despesa energètica, provocant un augment en el pes i el greix corporal, així com major predisposició a desenvolupar malalties cròniques. S'ha observat que en el desenvolupament de l'obesitat no solament intervé la dieta, sinó també factors genètics, endocrins, psicològics i ambientals. En les últimes dècades la microbiota intestinal també s'ha inclòs entre els factors que poden tindre una influència clau en l'obesitat i el metabolisme. La prevalença de l'obesitat especialment en xiquets i adolescents cada vegada és major, constituint un dels primers problemes de salut pública a nivell mundial. Per això, és necessari seguir avançant en la identificació dels factors que poden contribuir a l'obesitat i en el desenvolupament d'estratègies alternatives que permeten disminuir la seua prevalença $i$ les malalties associades a l'obesitat.

L'objectiu global de la tesi ha estat la identificació dels canvis en la composició de la microbiota intestinal associats a l'obesitat i la valoració de la funció de components específics de la microbiota en l'obesitat $i$ les alteracions metabòliques i immunològiques associades a un model animal.

El primer objectiu específic va ser determinar la influència d'una intervenció per al tractament de l'obesitat sobre la microbiota intestinal d'adolescents obesos $\mathrm{i}$ amb sobrepès. Mitjançant les tècniques de PCR a temps real o quantitativa (q-PCR) i hibridació in situ amb sondes fluorescents (FISH), es van quantificar els principals grups bacterians del tracte intestinal. Els 
adolescents que van experimentar major pèrdua de pes, van presentar augments de les concentracions o proporcions relatives dels grups Bacteroides o Bacteroides-Prevotella $i$ Lactobacillus, així com reduccions del grup E. rectale - C. coccoides. La microbiota dels adolescents que van experimentar una pèrdua de pes significativa es va caracteritzar per presentar majors concentracions inicials $\mathrm{i}$ finals dels grups $B$. fragilis, $C$. leptum $i B$. catenulatum i menors dels grups C. coccoides, Lactobacillus, Bifidobacterium, $B$. breve i $B$. bifidum, la qual cosa suggereix que la microbiota de l'individu pot influir en l'eficàcia de les intervencions basades en canvis en l'estil de vida per tractar l'obesitat.

En adolescents obesos es va detectar un augment de la proporció de IgA associada a bacteris intestinals, relacionat amb les proporcions de $C$. histolyticum $i$ E. rectale- $C$. coccoides, que es van reduir després de la intervenció per tractar l'obesitat, la qual cosa suggereix que alguns components de la microbiota possiblement implicats en l'obesitat o els seus metabòlits influeixen en el sistema immunitari de l'hoste. L'obesitat també s'associa a complicacions durant l'embaràs, incrementant el risc de salut del xiquet en néixer $\mathrm{i}$ el de patir obesitat $\mathrm{i}$ altres patologies relacionades. Per això es va plantejar també com a objectiu avaluar la composició de la microbiota intestinal de dones embarassades amb sobrepès per qPCR i la seva relació amb paràmetres bioquímics $\mathrm{i}$ dietètics. Les dones amb sobrepès van presentar menors concentracions dels grups Staphylococcus, Enterobacteriaceae $i$ E. coli, i reduccions en les dels gèneres Bifidobacterium i Bacteroides. L'augment d'E.coli i la reducció de Bifidobacterium spp. i Akkermansia muciniphila 
també es va associar al guany excessiu de pes durant l'embaràs. A més, els augments en la concentració de colesterol sèric es van relacionar amb augments en Staphylococcus spp., els augments en el colesterol HDL i reduccions en el colesterol total es van relacionar amb augments en Bacteroides spp., els augments en àcid fòlic es van relacionar amb augments en Bifidobacterium spp. i els nivells de ferritina i transferrina reduïda van mostrar relacions oposades amb les concentracions d'enterobacteris i Bifidobacterium spp. Per tot això, es pot afirmar que la microbiota intestinal està relacionada amb el pes corporal, amb el guany de pes i els paràmetres metabòlics durant l'embaràs, la qual cosa pot ser rellevant per a la salut de la mare i del fill.

Després d'haver estudiat la relació que existeix entre la microbiota intestinal i el metabolisme, el següent objectiu que es va plantejar va ser estudiar l'efecte del cep B. pseudocatenulatum CECT 7765 com a potencial probiòtic en un model animal d'obesitat. En animals amb obesitat induïda amb una dieta rica en greix, es va observar que l'administració d'aquest bacteri reduïa el colesterol, els triglicèrids, la glucosa, la leptina, l'esteatosi hepàtica i la grandària dels adipòcits pel que fa al grup obès no tractat amb el cep. Així mateix, va millorar la funció de cèl·lules inmunocompetents (macròfags i cèl·lules dendrítiques) i va modular la composició de la microbiota, reduint les seues propietats inflamatòries. Per tant, aquest cep millora les alteracions metabòliques i immunològiques associades a l'obesitat induïda per la dieta en un model murino. 


\section{SUMMARY}

Obesity is the result of imbalance between intake and energy expenditure, causing an increase in weight and body fat and more likely to develop chronic diseases. It has been observed that in the development of obesity not only involving the diet, but genetic, endocrine, psychological and environmental. In recent decades the intestinal microbiota has also been included among the factors that may have a key influence on obesity and metabolism. The prevalence of obesity especially in children and adolescents is increasing, making it one of the first public health problems worldwide. Therefore, further progress is needed in identifying the factors that may contribute to obesity and the development of alternative strategies for reducin the prevalence and comorbidity.

The overall objective of the thesis has been the identification of changes in the composition of the intestinal microbiota associated with obesity and assessment of the role of specific components of the microbiota in obesity and associated metabolic and immunological in an animal model.

The first specific objective was to determine the influence of an intervention for the treatment of obesity on the intestinal microbiota of obese and overweight adolescents. Using the techniques of real time PCR or quantitative (q-PCR) and in situ hybridization with fluorescent probes (FISH), quantified the major groups of bacteria of the intestinal tract. Adolescents who experienced greater weight loss, showed increases in concentrations or relative 
proportions of the Bacteroides group and Bacteroides-Prevotella and Lactobacillus, and reductions in group E. rectale - C. coccoides. The microbiota of adolescents who experienced a significant weight loss was characterized by higher initial concentrations and final group B. fragilis, $C$. leptum and B. catenulatum and lower group C. coccoides, Lactobacillus, Bifidobacterium, B. breve and B. bifidum, suggesting that the microbiota of the individual can influence the effectiveness of interventions based on changes in lifestyle to treat obesity.

In obese adolescents was an increase in the proportion of $\operatorname{IgA}$ associated with intestinal bacteria, related to the proportions of C. histolyticum and $E$. rectale - $C$ coccoides, which were reduced after surgery to treat obesity, suggesting that some components of the microbiota possibly involved in obesity or its metabolites influence the host immune system.

Obesity is also associated with complications during pregnancy, increasing the risk of child health at birth and suffer from obesity and other related pathologies. The question arose also as to evaluate the composition of the intestinal microbiota of pregnant women with overweight by qPCR and its relationship with biochemical and dietary parameters. Overweight women had lower concentrations of the groups Staphylococcus, Enterobacteriaceae and E. coli, and reductions in the genera Bifidobacterium and Bacteroides. E. increasing coli and reduction of Bifidobacterium spp. and Akkermansia muciniphila also associated with excessive weight gain during pregnancy. In addition, increases in serum cholesterol concentration were associated with 
increases in Staphylococcus spp., Increases in HDL cholesterol and reductions in total cholesterol were associated with increases in Bacteroides spp., Increases in folic acid were associated with increases in Bifidobacterium spp., levels of ferritin and transferrin showed opposing relationships with low levels of Enterobacteriaceae and Bifidobacterium spp. Therefore, we can say that the intestinal microbiota is related to body weight, with weight gain and metabolic parameters during pregnancy, which may be relevant to the health of the mother and child.

After studying the relationship that exists between the intestinal microbiota and metabolism, the next goal that was raised was to study the effect of strain $B$. pseudocatenulatum CECT 7765 as a potential probiotic in an animal model of obesity. Induced obesity in animals with a diet rich in fat, it was observed that the administration of the bacteria lowered cholesterol, triglycerides, glucose, leptin, hepatic steatosis and adipocyte size compared to untreated obese group with strain. Also improved the function of immunocompetent cells (macrophages and dendritic cells) and modulated the composition of the microbiota, reducing inflammatory properties. Therefore, this strain improved metabolic and immunologic alterations associated with obesity induced by diet in a murine model. 


\section{ÍNDICE}

* INTRODUCCIÓN

\section{1.- OBESIDAD}

$1.1 \quad$ Prevalencia de la obesidad y su impacto en la salud pública

1.2 Obesidad Infantil

4

1.3 Etiopatogenia de la obesidad y enfermedades asociadas

1.4 Prevención y Tratamiento

2.- MICROBIOTA INTESTINAL

2.1 Colonización y composición de la microbiota intestinal.

2.2 Microbiota Intestinal y Obesidad

2.2.1 Funciones de la metabólicas

2.2.2 Funciones inmunológicas

2.3 Cambios de la microbiota intestinal en individuos obesos

* EXPOSICIÓN GENERAL DEL PROBLEMA A 
* CAPÍTULO 1: Caracterización de la microbiota intestinal en adolescentes con sobrepeso y obesidad y obesidad mediante técnicas moleculares

1.1 Interplay between weight loss and gut microbiota composition in overweight adolescents

1.2 Shifts in clostridia, bacteroides and immunoglobulin-coating fecal bacteria associated with weight loss in obese adolescents

* CAPÍTULO 2: Correlaciones de la microbiota intestinal durante el embarazo en mujeres con sobrepeso y obesidad

2.1 Gut microbiota composition is associated with body weight, weight gain and biochemical parameters in pregnant women

\section{* CAPÍTULO 3: Evaluación del efecto de bacterias potencialmente} probióticas en un modelo animal de obesidad

3.1Bifidobacterium CECT 7765 improves metabolic and immunological dysfunction associated with obesity in high-fat diet fed mice 
* REFERENCIAS

\section{*ANEXOS}

1. Review article: Insights into the role of gut microbes in Obesity.

2. Rewiew article: Probiotics in the defence and metabolic balance of the organism, gut microbiota in obesity and metabolic disorders. 


\section{OBESIDAD}

\subsection{Prevalencia de la obesidad y su impacto en la salud pública}

La obesidad es uno de los principales problemas de salud a nivel mundial, y debido al rápido aumento de su prevalencia en los últimos años, se ha considerado una pandemia (Blancas-Flores, 2009). En los países industrializados ha pasado a ser el principal desorden nutricional (Wang, 2010), y una de las principales causas de muerte y discapacidad, amenazando muchos de los logros sanitarios alcanzados durante el último siglo (Gómez Ambrosi, 2008). Se estima que afecta a 400 millones de individuos y en niños podrían llegar a ser los 15 millones.

Cada vez son más los estudios que se están desarrollando sobre la obesidad debido a que las causas que conducen su aparición son complejas (Angelakis, 2012). La variación de la ganancia de peso sugiere que la obesidad no sólo esta influenciada por la ingesta calórica como antiguamente se consideraba, sino también por factores ambientales, genéticos, neurológicos, endocrinos y la actividad física (Schnitzler, 2012; Angelakis, 2012). La obesidad es consecuencia de un desequilibrio positivo y prolongado entre la ingesta y el gasto energético, que conlleva a un incremento excesivo del peso y grasa corporal (Monereo, 2004), está asociada a un mayor riesgo de sufrir diabetes mellitus tipo 2, hipertensión, hipercolesterolemia, enfermedades asociadas a hígado graso del tipo no alcohólico, artritis, enfermedad de Alzhaimer, algunos tipos de cáncer, mortalidad por enfermedades coronarias 
(Ferrante, 2007), además de incrementar el riesgo de apoplejía, problemas respiratorios, apnea del sueño y osteoartritis (Amber, 2007).

La proporción de grasa corporal puede ser medida de forma directa mediante diversas técnicas, como la hidrodensitometría, pletismografía, tomografía computarizada, resonancia magnética, absorciometría dual energética de rayos X o bioimpedanciometría (Martínez, 2010). Dichas técnicas no son comúnmente utilizadas en la práctica diaria para el diagnóstico rutinario de la obesidad, debido a que requieren equipos específicos y especializados, su utilización es más en la investigación. Sin embargo se puede recurrir a técnicas más accesibles, fáciles y reproducibles, basadas en la antropometría, como son el índice de masa corporal (IMC) (Sweeting, 2007), la medición del perímetro de cintura (PC), el cociente de cintura-cadera, la medición de pliegues cutáneos o el índice nutricional (Martínez, 2010).

El índice de masa corporal (IMC), que es la relación del peso en kilogramos sobre la talla al cuadrado en metros, es uno de los principales criterios antropométricos para realizar el diagnóstico del sobrepeso y la obesidad, debido a que el peso está estrechamente relacionado con la grasa corporal (Gómez-Barrado, 2011). La definición de sobrepeso y obesidad según la Sociedad Española para el Estudio de la Obesidad (SEEDO, 2000), en función del IMC se presenta en las tablas 1 y 2. 
Tabla 1. Clasificación del Índice de Masa Corporal

\begin{tabular}{cc}
\hline IMC $\left(\mathbf{k g} / \mathbf{m}^{\mathbf{2}}\right)$ & Estado corporal \\
\hline$<20$ & Delgadez \\
$20-25$ & Peso normal \\
$25-30$ & Exceso de peso \\
$30-40$ & Obesidad moderada \\
$>40$ & Obesidad mórbida \\
\hline
\end{tabular}

Tabla 2. Grados de obesidad

\begin{tabular}{cc}
\hline Grado & $\%$ :(Peso real / Peso ideal) $\times 100$ \\
\hline Normalidad & $90-110$ \\
Sobrepeso & $110-120$ \\
Obesidad Leve & $120-140$ \\
Obesidad moderada & $140-160$ \\
Obesidad intensa & $160-200$ \\
Obesidad mórbida & $>200$ \\
\hline
\end{tabular}

Fuente: modificada de SEEDO, 2000

Desde la década de los ochentas la Organización Mundial de la Salud (OMS) ha ido advirtiendo de la importancia de abordar el problema de la obesidad de forma prioritaria, Esto hace que el abordaje del tratamiento de la obesidad sea una de las prioridades de la sanidad pública internacional (Angelakis, 2012). Las estimaciones del coste económico que supondría el 
tratar las enfermedades crónicas inducidas por el sobrepeso y obesidad, indican que podrían llegar a ser una carga insostenible para los sistemas de salud pública (James, 2010). La OMS, estima que el cuidado de las patologías de los adultos con sobrepeso y obesidad representa el 6\% del gasto general en salud de los países europeos (Branka, 2010). Los costes indirectos relacionados con la discapacidad laboral en los individuos y las adaptaciones que debe tener la sociedad para dichos pacientes pueden llegar hasta un $4 \%$ del gasto bruto de una nación, como es el caso en China, en donde se estima que doble este porcentaje en 15 años (Popkin, 2007).

\subsection{Obesidad Infantil}

La obesidad en la edad infantil cada vez más se incrementa debido a los cambios de estilo en las civilizaciones occidentales (Troiano, 1998). El número de ingesta de comida al día, los ayunos prolongados, la baja ingesta de frutas, vegetales y granos, así como el alto consumo de carbohidratos y alimentos fritos, han demostrado una asociación con el sobrepeso y obesidad en escolares (Bernardo, 2012). Algunos autores resaltan la importancia del entorno en su desarrollo, debido a que en este trastorno nutricional influyen arraigadas y profundas normas sociales, difícilmente modificables (Oda, 2008).

Es difícil calcular de forma cuantitativa la prevalencia de la obesidad infantil a nivel mundial, debido a que no existe una definición aceptada internacionalmente (Zhao, 2011). Sin embargo, encuestas realizadas en 144 
países en el 2010, indican que 43 millones de niños (de los cuales 35 millones pertenecen a países desarrollados) en edad preescolar, tienen sobrepeso $u$ obesidad, y 92 millones están en riesgo de tener sobrepeso. La prevalencia mundial de la obesidad infantil aumentó de un $4.2 \%$ en 1990 a un $6,7 \%$ en 2010. De continuar así, se espera que en 2020 aumente a un 9.7\% o 60 millones de niños con sobrepeso u obesidad (Raj, 2012).

Se considera que aproximadamente, el $70 \%$ de los actuales adolescentes obesos, en edad adulta tendrán obesidad mórbida. Lo cual producirá un aumento en la incidencia en enfermedades crónicas en la siguiente generación adulta y por lo tanto una mayor incidencia de mortandad (Zhao, 2011).

La prevalencia de la obesidad y sobrepeso en España es del $26.3 \%$ en individuos de 2-24 años (Aranceta, 2007), y las cifras siguen aumentado. Un estudio realizado en Holanda mostró que solo el 34\% de los padres de adolescentes obesos tenían conocimiento de las causas que pueden provocar la obesidad, un $61 \%$ acerca del sobrepeso y un $49 \%$ de lo que es una dieta saludable (Booij, 2008). Otro estudio realizado en ese mismo país demostró que el $50 \%$ de los padres que tenían hijos obesos no reconocían el sobrepeso de sus hijos adolescentes, y al $87 \%$ de los padres no se preocupaban por el peso de sus hijos (Jansen, 2006). Los estudios realizados por Rosenbaum y Leibel (1998), con gemelos y hermanos adoptados generaron evidencias de que hay una fuerte influencia genética sobre el desarrollo del peso y composición corporal. 
Cuando se valora el peso de los padres de niños obesos el $50 \%$ de ambos progenitores son obesos. El riesgo de obesidad infantil se multiplica por 4 si un padre es obeso y por 8 si ambos padres lo son. Se ha visto que la distribución de la grasa es idéntica de padres a hijos, con lo cual se puede decir que el genotipo influye en esta relación, Dicha relación se confirmó cuando se estudiaron a niños adoptados y gemelos univitelinos y bivitelinos en donde la distribución de grasa que presentaban tenía mayor relación con la carga genética que con la convivencia diaria (Pufal, 2012). Es por ello la necesidad de una máxima divulgación de las buenas prácticas alimentarias y sus consecuencias, así como el saber la clasificación de sobrepeso y obesidad de acuerdo a cada etapa de la vida. Kroon (2010), en un estudio longitudinal identificó que el IMC cambia específicamente entre los 2 y 6 años de edad, siendo uno de los principales condicionantes del sobrepeso en la edad adulta, por lo tanto, el cambio de peso antes de los 2 años es muy importante lo cual se confirmó cuando se observó que el sobrepeso que se presentaba a los 2 años de edad seguía permanente hasta los 30 años, por lo cual se propone que una prevención antes de los 2 años puede ser un factor limitante para evitar la obesidad en adultos.

Recientes estudios epidemiológicos indican que la programación de la obesidad en la adolescencia puede ocurrir como resultado de la nutrición maternal durante el periodo prenatal y otros factores que impactan al ambiente intrauterino (Larson, 2011). David Barker (1989), propuesó la hipótesis del origen fetal de la obesidad, que sugiere que las alteraciones en el estado nutricional de la madre pueden dar como resultado una adaptación metabólica 
permanente en el feto, aumentando el riego de padecer enfermedades cardiovasculares, diabetes y obesidad a lo largo de su vida.

La clasificación del IMC es correcta para personas adultas, en donde la correlación peso-grasa esta estrechamente relacionada. Sin embargo, en la población infantil no se debería utilizar dicha clasificación debido a que el porcentaje de grasa corporal con respecto a la talla, no permite discriminar la distribución de la grasa y la masa magra en todo el cuerpo en estas etapas de crecimiento y maduración. Por lo que en individuos menores de 18 años se debe valorar por percentiles según edad, sexo y población (Gómez Barrado, 2011).

Examinando los estándares históricos para definir el sobrepeso en adolescentes se observa que la distribución del IMC cada vez es más desigual. La parte inferior de la distribución se ha desplazado relativamente poco mientras que la parte superior se ha ampliado considerablemente. Este hallazgo sugiere que muchos niños pueden ser más susceptibles genética o socialmente a la influencia de los cambios del entorno. La definición de la obesidad infantil sigue siendo un problema porque la mayoría de las definiciones utilizan una cierta variante del IMC, sin embargo ninguno de los métodos empleados están ampliamente disponibles y/o son fácilmente aplicables a la situación clínica (Gómez-Barrado, 2011). La definición de obesidad en la clínica se realiza indirectamente mediante el IMC y el perímetro de la cintura (PC), recurriendo a puntos de corte fijos para ambos, los cuales están bien establecidos en la edad adulta, pero que subestiman la prevalencia real cuando se usan en la etapa 
infanto-juvenil (Reilly, 2011). No existe consenso acerca de los puntos de corte para el sobrepeso y la obesidad en el niño y adolescente. Para el IMC se establece el percentil 95, tal y como recomienda el grupo europeo de obesidad infantil, o en otros estudios el percentil 97, y para el PC está bien establecido el percentil 90 como punto de corte (Gómez Barrado, 2011). Para la población infantil se utiliza el IMC z-score, que se refiere a cuánto se desvía la media del IMC de la población en estudio y en qué dirección respecto de la media de IMC de una distribución normal (Sardón, 2006).

Los principales problemas físicos en la obesidad infantil son complicaciones ortopédicas y apnea del sueño (Zhao, 2011). En cuanto a los problemas psicológicos que se pueden presentar son síntomas depresivos y baja autoestima (Parsons, 1999). Diversos estudios indican que existe una relación entre el sobrepeso u obesidad en la maduración sexual temprana en las niñas, en cuanto a los varones, los resultados son muy divergentes (Bernardo, 2012).

\subsection{Etiopatogenia de la obesidad y enfermedades asociadas}

A pesar de que la obesidad es un tema de gran interés y cada vez se realizan más estudios sobre ella, aún no es del todo clara su etiología. $\mathrm{Su}$ origen se relaciona con un conjunto complejo de factores tanto del tipo biológico, conductuales y ambientales, siendo difícil en cada caso particular valorar la importancia relativa de cada uno de ellos. Según la distribución de grasa corporal, la obesidad se clasifica en central o androide, (comúnmente 
llamada tipo manzana), con predominio de tejido graso en la región intrabdominal o periférica, y ginoide (comúnmente llamada tipo pera), con acumulo de tejido adiposo fundamentalmente en la región fémoro-glútea. Esta distribución varía según el género y la raza, siendo en la infancia predominantemente mixta. La diferencia en la distribución de la masa grasa corporal por géneros, fue descrita en 1940 y explicada parcialmente por las diferencias hormonales; los andrógenos se relacionan con un incremento del tejido adiposo visceral, asociándose con factores de riesgo cardiovascular, mientras que los estrógenos se relacionan con el tejido adiposo periférico o subcutáneo (Sweeting, 2007).

Durante la pubertad, acontecen cambios en la distribución de grasa corporal influenciados por la leptina, que inducen la secreción de GnRH (hormona liberadora de gonadotrofinas) y de gonadotropinas. Además, la leptina se correlaciona muy positivamente con el IMC, trasmitiendo información sobre la energía almacenada disponible al cerebro. La concentración sérica de leptina, se incrementa en las mujeres durante la pubertad, pero disminuyen en los varones después de iniciarse la misma, en el estadio 2 de maduración gonadal, originando el característico patrón androide y ginoide de distribución de grasa característico del adolescente y del adulto (Muñoz, 2007).

La mayoría de los niños obesos, presentan dicha enfermedad como consecuencia de una ingesta energética excesiva y/o un gasto calórico reducido y menos del $5 \%$ tienen una enfermedad como factor causal de la obesidad, por 
ello en la infancia se pueden considerar dos grandes formas de obesidad desde el punto de vista etiológico (Martínez, 2010):

1.- Obesidad nutricional, simple o exógena, idiopática o esencial: Es la más frecuente, un $95 \%$ de los casos es de esta naturaleza. Su etiopatogenia no se conoce perfectamente.

2.- Obesidad secundaria o sindrómica: Forma parte de la sintomatología de afecciones conocidas como síndromes dismórficos, endocrinopatías y lesiones del sistema nervioso central.

Las seis lesiones monogénicas principales que producen desordenes endócrinos y que conllevan obesidad en humanos, son:

a) Deficiencia congénita de leptina

b) Defectos en el receptor de leptina

c) Defectos en la pro-hormona convertasa I

d) Deficiencia en la proopiomelanocortina (POMC)

e) Defectos en el receptor de la melanocortina-4

f) Defectos en el receptor gamma-2 en el peroxisoma proliferador activado

A corto plazo el control de la ingesta está principalmente controlado por las vías de señalización que emanan del tracto gastrointestinal, incluidos los péptidos orexigénicos (grelina) que activan las señales de hambre y los 
péptidos anorexigénicos (coleocistocinina, péptido similar al glucagón 1 (GLP-1) y péptido tirosina-tirosina (PYY 3-36) que generan señales de saciedad. En el control de la ingesta a largo plazo parece ser primordiales las señales que emanan del tejido adiposo (leptina) y el páncreas (insulina) liberadas en respuesta a la ingesta de alimentos y los depósitos de grasa corporal (Konturek, 2004).

Hasta el momento se ha demostrado la relación de 32 genes del genoma humano con el IMC, sin embargo en un estudio que realizó Speliotes (2010), con 249,796 voluntarios observaron que de 18 loci que tenían relación con la obesidad, la contribución en el IMC de la población solo se presentó en un $2 \%$ de los casos. Es por ello que se deben considerar otros factores en el aumento del IMC, no solo el genético.

La obesidad también se considera un estado de inflamación crónica leve, caracterizado por una elevada producción de citoquinas y adipocinas proinflamatorias que contribuyen a alteraciones metabólicas de forma permanente (Sanz, 2009). La concentraciones de mediadores inmunológicos, como el factor de necrosis tumoral alfa (TNF- $\square$ ), la interleucina IL-6, la IL-1 $\beta$, la proteína quimioatrayente MCP1 y la leptina, suelen estar elevadas en la sangre periférica de los sujetos obesos, mientras que las de adiponectina, que parece tener efectos antiinflamatorios en la obesidad y mejorar la sensibilidad a la insulina, están reducidas (Tilg, 2006). Se ha visto que TNF- $\square$ está implicado en el desarrollo de la resistencia a la insulina porque incrementa de forma excesiva la fosforilación de serina en el sustrato receptor de la insulina 
intracelular-1 (IRS-1), provocando su inactivación (Hotamisligil, 1996). La resistencia a la insulina provoca una hiperinsulinemia y un cúmulo de lípidos en el hígado y en el tejido adiposo (Cani, 2007).

Desde el punto de vista energético, la masa del cuerpo puede ser dividida en dos diferentes compartimentos (Martínez, 2010):

(1) La masa corporal magra, en la cual la energía se almacena como carbohidratos y proteínas.

(2) La masa de grasa corporal, en la cual la energía se almacena como triacilglicerol.

El tejido adiposo es el órgano que más triacilglicerol almacena, en él, los adipocitos tienen una media de 1 microgramo de triacilglicerol por célula. Durante el desarrollo y crecimiento en la infancia, el peso y la composición corporal presentan continuos cambios fisiológicos. En el caso del tejido adiposo, la curva de producción de las células adiposas en la primera etapa de la vida, presentan dos picos máximos: el primero es desde el nacimiento hasta el primer año de vida y el segundo antes de comenzar la pubertad, en donde el incremento de grasa es mayor, ya que podría ser un detonante condicional para el inicio de esta etapa de desarrollo (Wabitsh, 2000). 
Introducción

\subsection{Prevención y Tratamiento}

\section{Prevención}

A nivel internacional, las estrategias preventivas que la OMS ha tomado, fue realizar en mayo de 2004, en la 57 Asamblea Mundial de la Salud, una "Estrategia Mundial sobre Régimen Alimentario, Actividad Física y Salud". Sus objetivos principales eran "reducir los factores de riesgo y de morbilidad, promover la concienciación y conocimiento general, y fomentar los planes políticos de actuación y seguimiento de la investigación científica”.

En 2005, el Ministerio de Salud y Consumo Español ideó la Estrategia para la Nutrición, Actividad física y Prevención de la Obesidad (estrategia NAOS) que tiene como objetivo: "fomentar una alimentación saludable y promover la actividad física para invertir la tendencia ascendente de la prevalencia de la obesidad y con ello, reducir sustancialmente, la morbilidad y mortalidad atribuible a las enfermedades crónicas" (Martínez, 2010). Dentro de este marco se estableció en septiembre de 2005 el código PAOS (Autorregulación de la Publicidad de los Alimentos) dirigida a menores, en el que se subscribieron 33 empresas españolas. Posteriormente, en mayo del 2007, en la Comisión de la Comunidad Europea celebrada en Bruselas, se estableció la estrategia europea sobre nutrición, sobrepeso y obesidad cuyo objetivo es: la promoción de la dieta saludable y la actividad física: una dimensión europea para la prevención del sobrepeso, la obesidad y las enfermedades crónicas. Las intervenciones preventivas sobre la obesidad infantil todavía no han demostrado mejorar la prevalencia de la misma, 
aunque, sí se muestran mejoras en el conocimiento y comportamiento poblacional (Summerbell, 2005).

Las estrategias preventivas deben incluir la recomendación de fomentar hábitos alimentarios y de actividad física adecuados. Estos deben incluir el control por parte de los progenitores del consumo proteico elevado, sobretodo en la etapa inicial de la vida, reducir las comidas de alta densidad energética, ricas en ácidos grasos saturados y trans, “comidas rápidas” y grandes porciones alimentarias, el incremento de fibra, frutas, verduras, y establecer un horario regular de comidas, sin prescindir del desayuno (Cañete, 2007). El éxito de estas medidas dependerá fundamentalmente de la implicación familiar creando un entorno propicio para el niño (McGovem, 2008).

\section{Tratamiento}

Los tratamientos tradicionales basados en las dietas hipocalóricas y el aumento de la actividad física han tenido cierto éxito en el control de la obesidad. Sin embargo, por lo general estas estrategias dan lugar a reducciones de peso limitadas y temporales (Sanz, 2009), o solo la perdida de un 10\% del peso inicial (Jubbin, 2012). Se sabe que en la obesidad al involucrarse múltiples factores, genéticos, endocrinos, psicológicos y de estilo de vida, se deben planear una estrategia más estructurada y global para que sean efectivas.

El tratamiento de los niños obesos debe ser precoz e individualizado, tras estudiar las comorbilidades que pueden presentarse en la infancia. El tratamiento debe estar basado en partes básicas, las cuales son motivación, 
dieta y ejercicio. El clínico debe indagar y conocer los hábitos de vida del niño, que generalmente son el reflejo de los familiares procurando una alimentación saludable, ajustando la energía ingerida a las necesidades reales, y promocionado la actividad física, siendo fundamental para ello el apoyo familiar (Dalmau, 2007). Tanto la hipertrofia del tejido subcutáneo como el incremento de grasa visceral son modificables a través de los cambios nutricionales y la actividad física. Se ha demostrado que la modificación de los hábitos de vida en la infancia, apoyados por la familia, provocan un modesto efecto sobre la obesidad, siendo menor sin la implicación familiar (disminución del IMC 1,5 k/m² y 0,4k/m², respectivamente) (Young, 2007).

Con la adopción y mantenimiento de estilos de vida saludables se consigue una mejoría en los parámetros metabólicos, con descenso del tamaño adipocitario y cambios en la expresión génica, descendiendo el estado inflamatorio subyacente a la obesidad (Skilton, 2006). Esto conlleva menor riesgo o mejoría de comorbilidades como la diabetes Mellitus tipo 2, dislipemia (disminuyendo el nivel de triglicéridos y de LDL-colesterol e incrementando el HDL colesterol e Hipertensión arterial) (Rector, 2007). En contraste, la disminución de grasa subcutánea utilizando una liposucción, no altera los niveles plasmáticos de la proteína $\mathrm{C}$ reactiva (PCR), interleucina IL6 , TNF- $\alpha$, ni adiponectina, y por lo tanto, no repercute sobre la sensibilidad a la insulina ni sobre el riesgo cardiovascular (Klein, 2004). Por lo cual no beneficia de manera significativa a las alteraciones metabolicas presentes. 
En casos especiales, se puede recurrir a la terapia farmacológica y/o quirúrgica, con unas indicaciones muy precisas en la edad pediátrica. La experiencia en la infancia de fármacos antiobesidad es muy limitada (Martínez, 2010). La Agencia de Administración de Fármacos y Alimentos (FDA) no aprueba el uso de los mismos en niños ni adolescentes jóvenes, por lo que se reserva a pacientes adolescentes en los que el crecimiento se encuentre finalizado. Las indicaciones son niños obesos en los que la dieta y el ejercicio físico han fracasado o niños con sobrepeso, con comorbilidades severas y antecedentes familiares de diabetes mellitus 2 o enfermedades cardiovasculares precoz (August, 2008).

Finalmente, la cirugía bariátrica se contempla como la última opción terapéutica, siendo las indicaciones en la infancia muy restrictivas, debido a que la pérdida brusca de peso puede influir negativamente en el crecimiento. Además, generalmente las comorbilidades de la obesidad en la infancia son menos graves y el pronóstico de la misma es mejor (Dalmau, 2007).

Debido a que no se recomienda utilizar estrategias quirúrgicas ni farmacológicas en menores de edad, dado que las modificaciones metabólicas pueden generar daños colaterales, se debe de recurrir a terapias menos agresivas pero efectivas. 


\section{MICROBIOTA INTESTINAL}

En décadas pasadas se creía que todos los microorganismos podían ser agentes causales de infecciones en cualquier parte que se encontraran en el hospedador, sin embargo, actualmente se sabe que la relación microorganismo - hospedador en muchos casos presenta una interacción de comensalismo no patogénico o mutualismo (Dethlefsen, 2007).

Tradicionalmente, el término más empleado para hacer referencia a las comunidades microbianas que se desarrollaban en el cuerpo de un hospedador sano era el de "flora" o "microflora (Langa, 2006). Actualmente se utiliza la palabra microbiota, para denotar al conjunto microorganismos presentes en el hospedador, y el termino microbioma, para referirse al conjunto de genes microbianos (Backhed, 2004; Vrieze, 2010). La microbiota intestinal es heterogénea y se estima que puede estar integrada por más de 1000 especies bacterianas distintas. El número de células microbianas en el lumen es 10 veces mayor que las células eucariotas del organismo lo que representaría alrededor de $1 \mathrm{~kg}$ del peso corporal (Scarpellini, 2010). Además, el microbioma es 100 veces mayor que el genoma humano, por lo cual, la microbiota intestinal puede ser considerada como un órgano virtual exteriorizado, metabólicamente adaptable y flexible, así como rápidamente renovable, que contribuye al metabolismo y tiene un papel importante en la obtención de energía a partir de la dieta (Francois-Pierre, 2009). En diversos estudios se ha observado que los

animales libres de gérmenes muestran alta susceptibilidad a infecciones, 
indicando que los simbiontes intestinales suponen una importante barrera para la colonización de patógenos potenciales, a este proceso se le ha llamado “exclusión competitiva”, en donde ambos grupos o microorganismos compiten por el mismo nicho ecológico, nutrientes y sitios de adhesión (Bik, 2009).

\subsection{Colonización y composición de la microbiota intestinal.}

El tracto gastrointestinal del feto en el útero, se considera prácticamente estéril, pero en el momento de nacer es rápidamente colonizado con microorganismos de la madre y del ambiente hospitalario (Palmer, 2007), después de 3 o 4 semanas del nacimiento la microbiota intestinal comienza ha estabilizarse. Sin embargo, algunos estudios han demostrado la existencia de bacterias en muestras de líquidos amnióticos y sangre de cordón umbilical obtenidos de madres/neonatos sanos, en el meconio de niños nacidos tanto por parto como por cesárea (Langa, 2006).

Los primeros colonizadores en el momento de nacer son bacterias anaerobias facultativas, estreptococos y coliformes, posteriormente predominan las bacterias anaerobias estrictas de los géneros Clostridium, Bacteroides y Bifidobacterium (Mackie, 1999). Las bacterias que predominan en las primeras semanas del nacimiento (Streptococcus, Enterococcus, Staphylococcus, Lactobacillus) están también muy relacionadas con los grupos bacterianos representativos en la leche materna. Estas bacterias pueden producir un ambiente reductor favorable para la colonización de bacterias anaerobias (Bifidobacterias, Bacteroides, y Clostridium) (Langa, 2010). La 
introducción de la alimentación complementaria también influye en la microbiota que va evolucionando hasta los 2-4 años de edad en los que alcanza una composición más estable que permanece con pocos cambios hasta la edad adulta (Scarpellini, 2010; Vrieze, 2010). En el establecimiento de la microbiota influyen muchos factores, como el tipo de parto, el ambiente, el tipo de lactancia y posiblemente hasta el genotipo (Mackie, 1999).

La microbiota intestinal es cuanti y cualitativamente diferente en cada individuo, depende de la edad, factores ambientales y de la dieta (Scarpellini, 2010), al parecer las poblaciones dominantes suelen permanecer estables a lo largo del tiempo (Zoetendal, 2001). Sin embargo, la composición microbiana puede sufrir alteraciones por el suministro de antibióticos (Deethlefsen, 2008). La edad también conlleva cambios en la composición de la microbiota y por ejemplo, el número de Clostridium spp. aumenta a lo largo de la vida mientras que el de Bifidobacterium spp. disminuye. En ancianos es más frecuente el aislamiento de Clostridium difficile, mohos y enterobacterias que en individuos jóvenes (Langa, 2006). Aunque la asociación entre el tipo de dieta y los distintos grupos microbianos aún no está clara, la microbiota de comunidades occidentales (caracterizada por una ingesta alta en grasa y proteínas de origen animal y un bajo contenido en fibra), parece contener mayores niveles de Bacteroides spp. y Clostridium spp. y con menores niveles de bacterias lácticas en comparación con la de comunidades orientales (Hayashi, 2002).

Alrededor de 50 filos bacterianos han sido descritas en la microbiota humana, pero solo tres son dominantes en el adulto: Firmicutes, Bacteroidetes 
y Actinobacteria (Zoetendal, 2006). Los Firmicutes es el phylum más abundante y contiene alrededor de 200 géneros, incluyendo Lactobacillus, Mycoplasma, Bacillus y Clostridium. El filo Bacteroidetes, incluye aproximadamente 20 géneros y el filo Actinobacteria se presentan en menor proporción (Vrieze, 2010). En la tabla 3 se describe a detalle los grupos representativos en las principales partes del tracto gastrointestinal.

Tabla 3. Microbiota del tracto gastrointestinal

\begin{tabular}{|c|c|c|}
\hline Localización & Grupos bacterianos & $\begin{array}{c}\text { Concentración } \\
\text { (UFC) }\end{array}$ \\
\hline Esófago & Streptococcus, Prevotella, Veillonella & $10^{1}-10^{3} / \mathrm{ml}$ \\
\hline Estómago & $\begin{array}{c}\text { Bacteroides, Enterobactericeae, } \\
\text { Lactobacillus, Streptococcus }\end{array}$ & $10^{7} / \mathrm{ml}$ \\
\hline Duodeno & $\begin{array}{c}\text { Bacteroides, Enterobactericeae, } \\
\text { Lactobacillus }\end{array}$ & $10 / \mathrm{ml}$ \\
\hline Yeyuno + Íleo & $\begin{array}{c}\text { Bacteroides, Clostridium, } \\
\text { Lactobacillus, Enterobacterias, } \\
\text { Enterococcus, Streptococcus }\end{array}$ & $10^{9} / \mathrm{g}$ \\
\hline Colon & $\begin{array}{c}\text { Bacteroides, Bifidobacterium, } \\
\text { Clostridium, Enterobactericeae, } \\
\text { Enterococcus, Eubacterium, } \\
\text { Lactobacillus, Metanobacterias, } \\
\text { Pseudomonas, Estafilococcus, } \\
\text { Streptococcus, }\end{array}$ & $10^{14} / \mathrm{g}$ \\
\hline
\end{tabular}

Fuente: Modificada de Holzapfel, 2006 
Introducción

\subsection{Microbiota Intestinal y Obesidad:}

La microbiota que coloniza el intestino humano, se considera un nuevo factor implicado en la obesidad y en las enfermedades asociadas debido a su influencia en las funciones metabólicas e inmunológicas del hospedador (Sanz, 2009). Se ha visto que el proceso de colonización intestinal aumenta la capacidad del hospedador, tanto para extraer energía de la dieta como para almacenarla en los adipocitos por diversos mecanismos (Backhed, 2004). La colonización del intestino en animales libres de gérmenes también provoca un aumento en la expresión en el hígado de dos enzimas claves implicadas en la ruta de biosíntesis de novo de ácidos grasos, la acetil-CoA carboxilasa y la sintasa de ácidos grasos, así como de los factores de transcripción ChREBP y SREBP-1, que están involucrados en la respuesta lipogénica de los hepatocitos a la insulina y glucosa (De Graaf, 2008).

Backhed y su equipo (2004), realizaron un estudio colonizando el tracto digestivo de ratones libres de gérmenes, con microbiota autóctona de ratones alimentados con una dieta normal. Después de 10 a 14 días observaron un incremento significativo en la grasa corporal sin tener una mayor ingesta del alimento. Este cambio abarco diferentes mecanismos:

1) fermentación microbiana de polisacáridos de la dieta, que no pueden ser digeridos por las enzimas del hospedador.

2) Por consiguiente, incremento de la absorción intestinal y en el íleon de monosacáridos y ácidos grasos de cadena corta. 
3) Conversión de los ácidos de cadena corta a lípidos más complejos en el hígado

4) Regulación microbiana de los genes del hospedador que promueven la deposición de los lípidos en los adipocitos.

La endotoxemia metabólica que se caracteriza por un aumento a niveles séricos de LPS y se asocia a dietas ricas en grasa, la resistencia a la insulina y la diabetes en modelos animales sometidos a una dieta rica en grasas se considera que puede ser un factor inflamatorio causante del aumento de peso corporal (Cani, 2007; Siebler, 2008).

En un estudio de Basseri y colaboradores (2012), demostraron que la principal bacteria responsable de las elevadas cantidades de metano en el colon es Methanobrevibacter smithii y que existe una estrecha correlación entre la cantidad de metano en la cavidad oral y el aumento del IMC en animales. Proponen dos mecanismos de acción del metano:

(1) En un estudio in vivo en roedores, el gas disminuyo el transito en la porción distal del intestino en un 59\%, esta disminución de movimientos podrían contribuir a un incremento en la cantidad de bacterias en el colon,

(2) Las bacterias metanogénicas aceleran la fermentación de polisacáridos y carbohidratos, incrementando la producción de ácidos de cadena corta que son absorbidos por el intestino y sirven como una fuente adicional de energía, esta energía extra puede ser precursora del aumento de peso en el hospedador (Basseri, 2012). 
Introducción

Las principales funciones de la microbiota intestinal son del tipo metabólicas, tróficas, y reguladoras del sistema inmunitario (Hooper, 2001). La presencia de una microbiota intestinal no es esencial para la supervivencia del organismo, pero se ha observado que en ratones libres de gérmenes (germfree, GF), requieren un 30\% más de energía en su dieta, suplementos de vitamina $\mathrm{K}$ y ciertas vitaminas del complejo B en comparación a animales con una microbiota normal. En animales con una microbiota autóctona estas vitaminas son producidas por diferentes géneros bacterianos, incluyendo a los Bacteroides y Eubacterium (Bik, 2009).

\subsubsection{Funciones metabólicas}

La función metabólica de la microbiota intestinal es esencial para la actividad bioquímica global del organismo, ya que interviene en la obtención de energía de la dieta, digestión y síntesis de nutrientes así como en la generación de compuestos absorbibles y en la producción de vitaminas (Reid, 2003; Bik, 2009).

Los mamíferos no pueden degradar los polisacáridos presentes en la pared celular de las plantas por si solos, sin embargo, la microbiota intestinal presenta enzimas que pueden degradar ese tipo de carbohidratos. La fermentación microbiana de alimentos no digeribles, pueden proveer aproximadamente el $10 \%$ de la energía diaria en los omnívoros y hasta un $70 \%$ en los herbívoros (Delzenne, 2007). Esto se corroboró al secuenciar el genoma de Bacteroides thetaiotaomicron, en donde se relacionaron 400 
enzimas para el transporte, unión y digestión de azúcares complejos, como el almidón (Hooper, 2002).

Como se puede observar en la figura 1, la degradación de los polisacáridos (xilano, pectina, almidón, manano e inulina) en la mucina del hospedador permite la producción de productos intermediarios (lactato, succinato, etc), gases (dióxido de carbono, hidrógeno y metano), etanol, ácido láctico y ácidos grasos de cadena corta (SCFAs, por sus siglas en ingles, short chain fatty acids) que incluyen al acetato, butirato y propionato, los cuales representan la principal fuente de energía de los colonocitos (Sanz, 2008; De Palma, 2011).

El hidrógeno que es producido durante la fermentación de los polisacáridos, puede activar el metabolismo y aumentar la proliferación de bacterias degradadoras de polisacáridos (Tilg, 2011). El acetato puede contribuir a la síntesis de colesterol y lípidos en el hígado por la activación de la acetil-S CoA sintetasa 2 del citosol, mientras que el propionato puede inhibir la síntesis de lípidos provenientes del acetato, al menos esto se ha observado en hepatocitos de roedores (Collins, 1994), Ambos se han visto involucrados en la regulación del metabolismo hepático de la glucosa reduciendo la glucemia postprandrial y la respuesta insulínemica (Verter, 1995; Lasaga, 2010). El butirato ejerce un efecto trófico sobre la mucosa, constituye la principal fuente de energía para los enterocitos y regula el crecimiento y/o diferenciación celular. También se le ha atribuido efectos anti-inflamatorios y anticarcinogénicos aunque su efectividad in vivo se desconoce. 


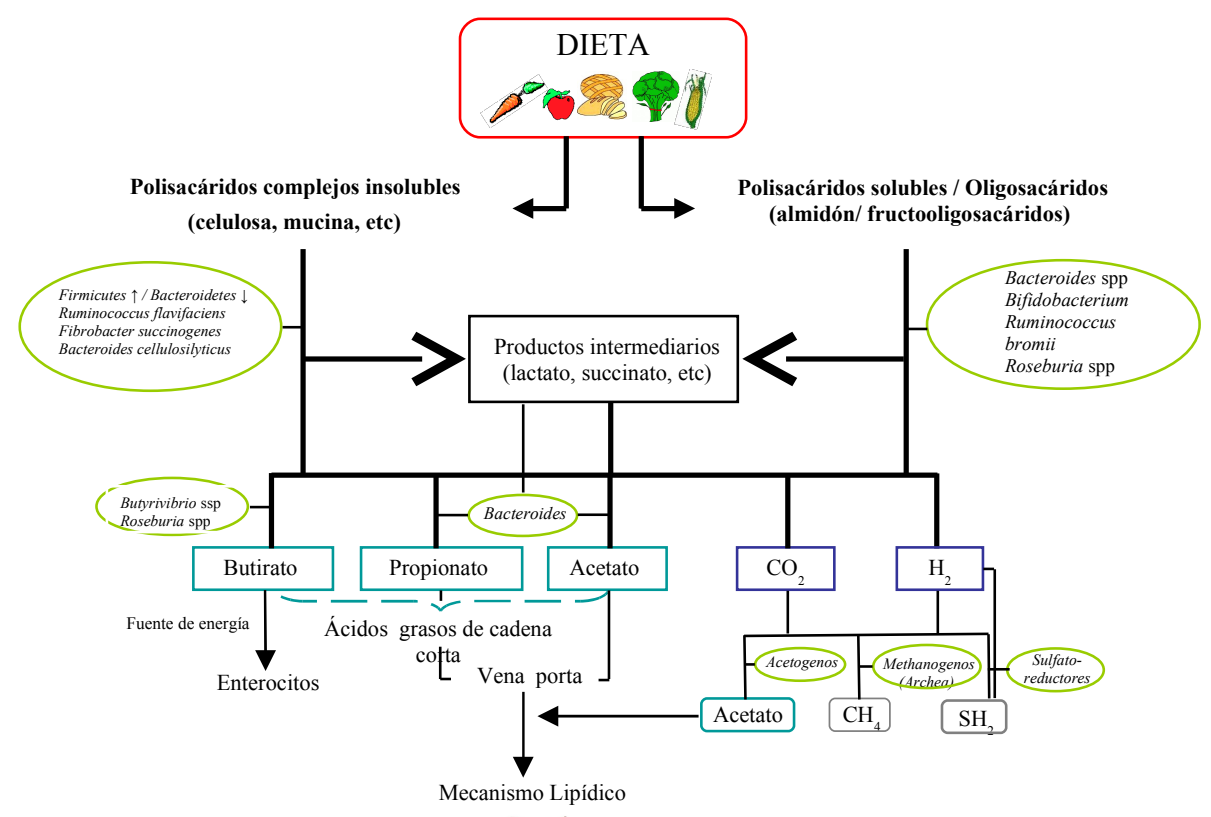

TP

Figura 1. Diagrama esquemático de las principales rutas metabólicas de poli y oligosacáridos en el ecosistema gastrointestinal

(Fuente: Modificado de Sanz, 2008). 
Además tanto el propionato como el butirato aumentan la sensación de saciedad, por lo cual podrían contribuirla control del apetito. La actividad metabólica de la microbiota también puede contribuir a la generación de compuestos perjudiciales para la salud, como se da en el caso de la degradación bacteriana de las proteínas que puede generar algunos metabolitos como amoniaco, aminas, índoles y fenoles (De Palma, 2011).

\subsubsection{Funciones inmunológicas}

El epitelio intestinal, el sistema inmune y la microbiota intestinal representan un sistema morfo-funcional responsable del balance dinámico así como de la integridad de la función de barrera del intestino del hospedador (Langa, 2006).

En el epitelio intestinal se encuentran diferentes tipos de células, enterocitos, células globet secretoras de mucus, células enteroendocrinas y células de Paneth que secretan péptidos antimicrobianos y proteínas (Sanz, 2009; Winkler, 2007). Consiste de una única capa de células unidas por uniones intercelulares estrechas que forman una capa impermeable a la mayoría de macromoléculas entre el contenido de la luz intestinal y el organismo (De Palma, 2011). 
Introducción

La integridad de la mucosa intestinal depende de diferentes factores: físicos, fisiológicos, inmunológicos, la dieta, la edad, el uso de antibióticos y la composición de la microbiota intestinal residente (De Palma, 2011). Se ve atacada constantemente por la presencia de antígenos externos y microorganismos patógenos y es un sitio activo para la supresión inmune de reacciones nocivas innecesarias, también se encarga de generar respuestas protectoras para mantener la homeostasis inmune del hospedador (Yuan, 2004).

La microbiota intestinal regula muchos aspectos de la inmunidad innata y la adquirida hecho se ha observado que en animales libres de gérmenes, el tejido linfoide asociado a la mucosa intestinal (GALT, por sus siglas en inglés: Gut associated lymphoid tissue) es inmaduro, presentan ausencia de placas de Peyer, reducción del número de células plasmáticas, bazo y nódulos linfáticos anormales y vellosidades intestinales inmaduras. Tan solo con la colonización de especies de Bacteroides se pueden reparar las deficiencias mencionadas (Hooper, 2004). Las continuas interacciones entre el sistema inmunitario y la microbiota intestinal son las responsables del estado de "inflamación controlada" existente en el tracto gastrointestinal, necesario para la generación rápida de una respuesta inflamatoria frente a patógenos (Neish, 2000).

Los receptores de reconocimiento celular de las células del sistema inmunitario innato, como los receptores Toll Like (TLR), constituyen el punto de partida de la inmunidad que se activa en respuesta a los estímulos 
microbianos o derivados de la dieta (proteínas, lípidos) e informa a las células inmunocompetentes para que respondan adecuadamente a éstos (Sanz, 2008). De este modo, componentes de bacterias patógenas y las comensales, son reconocidos desencadenando diversas respuestas.

Tras su activación por un ligando, los TLR interactúan con diferentes proteínas adaptadoras que activan la transcripción de distintos sistemas efectores y la síntesis de diversas citoquinas y mediadores inmunológicos de la inflamación. Se ha demostrado que tanto los lipopolisacáridos (LPS) de las bacterias Gram-negativas como los ácidos grasos saturados de la dieta pueden activar el TLR4 e inducir la síntesis de citoquinas TNF alfa IL-6, IL-1B, y quimocinas proinflamatorias relacionadas con la inducción de resistencia a la insulina y el aumento de la adiposidad, tanto en adipocitos, como en macrófagos, por rutas similares (Tsukmo, 2007). No obstante, todavía no se sabe con precisión si la inflamación es una causa o consecuencia de alteraciones como la resistencia a la insulina (Hotamisligil, 2006). En la figura 2 se muestra la activación de los TLR.

La cirugía bariátrica es uno de los procedimientos más eficaces para tratar la obesidad mórbida, mejora las condiciones metabólicas e inflamatorias, pero se sabe poco de su relación con la microbiota intestinal. Zhang (2009), realizó un estudio antes y después de someter a pacientes a la cirugía bariátrica, observó que antes de la cirugía los recuentos de Bacteroides, Prevotella y Archea, estaban elevados, las cuales son productoras y captadoras de hidrógeno, respectivamente. La transferencia del hidrógeno aumenta la 
energía de absorción por el intestino, lo cual repercute en un aumento en la producción de ácidos grasos de cadena corta que son absorbidos por el intestino (Samuel, 2006).

Otro estudio demostró que después de la cirugía las cantidades de los grupos de bacterias metanogénicas y Prevotellacaea se redujeron y disminuyeron las cantidades de Firmicutes (Zhang, 2009). En estudios realizados con ratas no obesas con cirugía bariátrica, se observó que los Firmicutes y los Bacteroidetes disminuyen su cantidad inicial en comparación

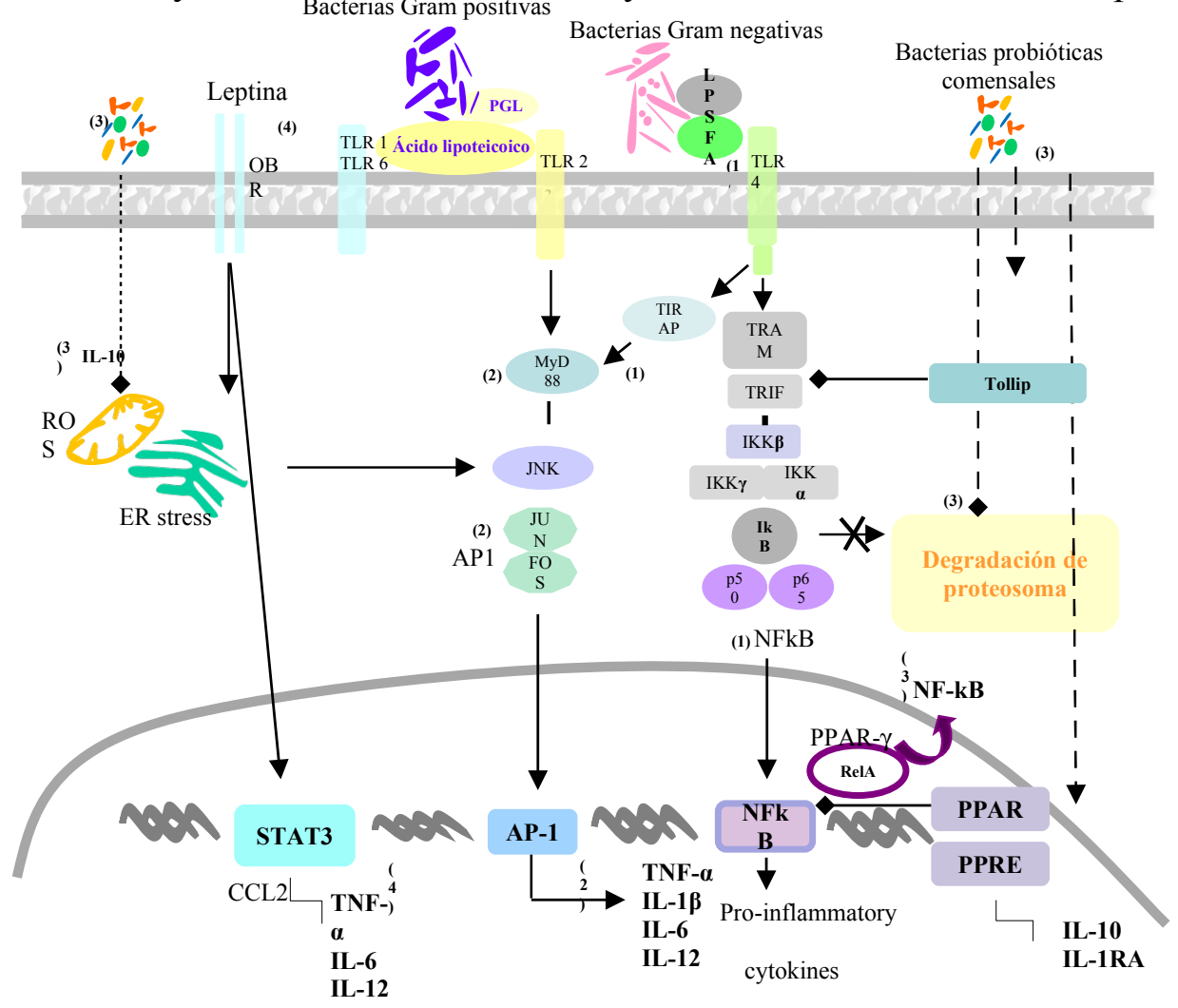

Figura 2. Diagrama de las rutas de señalización generadas por los componentes bacterianos, los ácidos grasos saturados y adipoquinas en células epiteliales y del sistema inmune innato 
produciendo una activación o regulación negativa de las rutas proinflamatorias, relacionadas con la obesidad y la resistencia a la insulina ( Sanz, 2008).

al grupo control. Sin embargo las Proteobacteria aumentaban hasta 52 veces su cantidad inicial ( $\mathrm{Li}, 2011)$. Las intervenciones quirúrgicas en el tracto gastrointestinal tienen profundos efectos en la composición de la microbiota intestinal y de los ácidos grasos de cadena corta. No obstante, la cirugía puede inducir una desnutrición (Kootte, 2012).

\subsection{Cambios de la microbiota intestinal en individuos obesos}

La obesidad se ha asociado a aumentos en la abundancia relativa de Firmicutes y reducciones proporcionales en la abundancia de Bacteroidetes, mediante la comparación de la composición de la microbiota intestinal de ratones genéticamente obesos (ratones deficientes en leptina ob/ob) y delgados. (Sanz, 2009). En un estudio realizado por Ley (2005), al analizar secuencias del 16S rRNA de ratones obesos y delgados observaron que los cambios que ocurrían en la microbiota intestinal eran a nivel de división. La microbiota del ciego de los ratones obesos presentó una diferencia significativa del 50\% de reducción en Bacteroidetes con respecto a los ratones delgados y era significativamente diferente con respecto a Firmicutes. Esta relación también se ha asociado a la obesidad en humanos. En un estudio con humanos obesos que se sometieron durante un año a una dieta hipocalórica, se observó un incremento significativo en las proporciones de Bacteroidetes, paralelo a la pérdida de peso (Ley, 2006). Turnbaugh (2009), comparó la microbiota de 
gemelos obesos y delgados, demostrando una menor proporción de Bacteroidetes y mayor en Actinobacteria en los individuos obesos. El incremento en el ratio Firmicutes/Bacteroidetes en ratones obesos $o b / o b$ puede ayudar a promover el incremento de adipocitos o podría representar una respuesta adaptativa al almacenamiento.

En otros estudios sobre la microbiota de ratones genéticamente obesos y delgados también se ha establecido una relación entre la obesidad y una mayor proporción de Archea (Ley, 2005). En estudios mas recientes también se ha detectado una reducción de Bifidobacterium y un aumento de Halomonas y Sphingomonas en la microbiota intestinal de ratas Zucker genéticamente obesas (fa/fa) en comparación con el grupo control (Waldram, 2009).

Patrice Cani (2009), demostró que una dieta alta en grasas disminuye el número de bifidobacterias e incrementa el LPS en plasma, también observó que la modulación de la microbiota intestinal mediante antibióticos o con una dieta de oligofructosa reduce la intolerancia a la glucosa, diminuye la ganancia de peso e inhibe la inflamación en ratones obesos. Estos resultados sugieren que los cambios en la microbiota pueden ser los responsables del incremento de endotoxinas en el plasma por los una dieta rica en grasa, lo cual puede contribuir a desencadenar obesidad y diabetes mellitas (Membrez, 2008). Otra ruta alternativa para la inflamación, es la disminución de butirato en plasma, ya que este compuesto tiene propiedades antiinflamatorias (Säemann, 2000). Los dos principales grupos bacterianos productores de butirato son Roseburia/E.rectale y especies de F.prausnitzii. Se ha visto que una dieta rica 
en carbohidratos no digeribles estimula el crecimiento de estos grupos bacterianos y por consiguiente se tiene un aumento de butirato en plasma (Gao, 2009). Al final de este apartado puede añadir un párrafo que resuma el posible uso de probióticos en obesidad.

Los beneficios que se pueden derivar de la modificación de la microbiota intestinal han generado desde hace décadas, un gran interés por el desarrollo de probióticos para la mejora o prevención de ciertas patologías (Langa, 2006). En este contexto y en base a la las funciones que las bacterias intestinales desempeñan en el metabolismo y la regulación del sistema inmune, también se ha propuesto en los últimos años el uso de bacterias probióticas y prebióticos como alternativa para prevenir o controlar la obesidad y comorbilidades, como la diabetes, cuyos resultados más destacados se discutirán en los capítulos de la tesis doctoral. 


\section{EXPOSICIÓN GENERAL DEL PROBLEMA A INVESTIGAR Y OBJETIVOS}

La obesidad se ha convertido en las últimas décadas en una de las principales causas de muerte y discapacidad (Gómez Ambrosi, 2008). Es una enfermedad crónica derivada de un desequilibrio entre la ingesta y el gasto energético, que provoca un incremento del peso y grasa corporal, y está asociada a un mayor riesgo de sufrir otras enfermedades como la diabetes Mellitus tipo 2 y la esteatosis hepática, así como de mortalidad por enfermedades coronarias. Además, la obesidad se considera asociada a un estado de inflamación de bajo grado relacionado con alteraciones crónicas del metabolismo. Esto hace que el abordaje del tratamiento de esta enfermedad suponga un serio problema público (González, 2008). La obesidad en la adolescencia constituye un antecedente metabólico principalmente para la enfermedad cardiovascular en el adulto y la diabetes tipo 2. La prevalencia de la obesidad y sobrepeso en España es del $26.3 \%$ en individuos de 2-24 años (Aranceta, 2007).

La microbiota intestinal comensal y su genoma (microbioma), que posee una capacidad codificante muy superior a la del genoma humano, contribuyen de forma significativa al metabolismo global del organismo; por esto, se ha considerado que actúa como un órgano equivalente al hígado (Bäckhed, 2004). La microbiota puede aportar nuevos nutrientes, favorecer su digestión y modular la expresión de genes del hospedador implicados en el 
metabolismo de macronutrientes y la deposición de lípidos (Sanz, 2008a). Además, la microbiota comensal regula muchos aspectos de la inmunidad innata y adquirida, por lo que su composición también se ha asociado estrechamente con patologías inflamatorias.

En los últimos años la composición de la microbiota se ha empezado a relacionar con la obesidad y su modificación se ha propuesto como alternativa para su prevención o control, aunque todavía existen pocos datos conclusivos al respecto. Por este motivo, en la presente tesis doctoral se planteó avanzar en el análisis de la microbiota intestinal y su asociación con la obesidad en diversos grupos de población y su interrelación con la dieta, y estudiar el efecto del uso de posibles probióticos en modelos animales de obesidad.

\section{Objetivos específicos:}

1.- Determinar la influencia de un programa multidisciplinar para tratamiento de la obesidad en adolescentes con sobrepeso, basado en una dieta con restricción calórica y aumento de la actividad física, sobre la composición de su microbiota intestinal y su relación con parámetros dietéticos, bioquímicos e inmunológicos, mediante el uso de PCR a tiempo real (qPCR) e hibridación in situ con sondas fluorescentes. 
2.- Determinar la composición de la microbiota intestinal de mujeres embarazadas normo peso y con sobrepeso y su relación con el peso corporal, la ganancia de peso durante el embarazo y los parámetros dietéticos y bioquímicos, mediante qPCR.

3.- Evaluar los efectos de la administración oral de la cepa Bifidobacterium pseudocatenulatum CECT 7765 en las disfunciones inmunológicas y metabólicas asociadas a la obesidad en un modelo animal alimentado con una dieta rica en grasa. 


\section{Interplay between weight loss and gut microbiota composition in overweight adolescents}

Obesity, 2009, Oct 17 (10), pp: 1907-1915

Arlette Santacruz ${ }^{1}$; Maria Carmen Collado ${ }^{1}$, Ascensión $\operatorname{Marcos}^{2}$, Julia Warnberg ${ }^{2,3}$, Amelia Martí ${ }^{4}$, Miguel Martin-Matillas ${ }^{5}$, Cristina Campoy ${ }^{5}$, Luis Moreno $^{6}$, Oscar Veiga ${ }^{7}$, Carlos Redondo-Figuero ${ }^{8}$, Jesús M. Garagorri ${ }^{9}$, Cristina Azcona ${ }^{4}$, Manuel Delgado ${ }^{10}$, Miguel García-Fuentes ${ }^{8}$ and Yolanda Sanz ${ }^{1 *}$

'Instituto de Agroquímica y Tecnología de Alimentos (CSIC), Apartado 73, 46100 Burjassot, Valencia, Spain; ${ }^{2}$ Grupo de Inmunonutrición, Instituto del Frío (CSIC), Madrid, Spain. ${ }^{3}$ Dept. Biosciences and Nutrition. Karolinska Institutet, Sweden. ${ }^{4}$ Departamento de Fisiología y Nutrición, Universidad de Navarra, Pamplona Spain; ${ }^{5}$ Departamento de Pediatría, Facultad de Medicina, Universidad de Granada, Granada, Spain; ${ }^{6} E U$ Ciencias de la Salud, Universidad de Zaragoza, Spain; ${ }^{7}$ Departamento de Educación Física, Deporte y Movimiento Humano, Universidad Autónoma de Madrid, Madrid, Spain. ${ }^{8}$ Departamento de Ciencias Médicas y Quirúrgicas, Universidad de Cantabria, Santander, Spain; ${ }^{9}$ Departamento de Pediatría, Radiología y Medicina Física, Universidad de Zaragoza, Spain. ${ }^{10}$ Facultad de Ciencias de la Actividad Física y Deporte; Universidad de Granada, Spain.

*Corresponding author: Yolanda Sanz, Instituto de Agroquímica y Tecnología de Alimentos (CSIC) PO Box 73, 46100 Burjassot, Valencia, Spain. Phone: +34 963900022; Fax: +34 963900022; E-mail: yolsanz@,iata.csic.es

Running head: Weight loss and gut microbiota 


\begin{abstract}
The aim of this study was to determine the influence of an obesity treatment program on the gut microbiota and body weight of overweight adolescents. Thirty-six adolescents (14-15 years), classified as overweight according to the International Obesity Task Force body mass index (BMI) criteria, were submitted to a calorie-restricted diet (10-40\%) and increased physical activity (15-23 kcal/kg body weight/wk) program over 10 weeks. Gut bacterial groups were analyzed by quantitative real-time PCR before and after the intervention. A group of subjects $(n=23)$ experience more than $4.0 \mathrm{~kg}$ weight loss and showed significant BMI $(P=0.030)$ and BMI z-score $(P=$ $0.035)$ reductions after the intervention, while the other group $(n=13)$ showed less than $2.0 \mathrm{~kg}$ weight loss. No significant differences in dietary intake were found between both groups. In the high weight-loss group, Bacteroides and Lactobacillus counts increased ( $P=0.015$ and $P=0.002$, respectively), whereas Clostridium coccoides and B. longum counts decreased $(P=0.001$ and $P=0.044$, respectively) after the intervention. Bacteroides and $C$. leptum counts were significantly higher $(P=0.004$ and $P<0.001$, respectively) while levels of $C$. coccoides, Lactobacillus, Bifidobacterium and B. breve were significantly lower $(P<0.001, P<0.001$ and $P=0.001$, respectively) in the high weight-loss group than in the low weight-loss group before and after the intervention. These findings indicate that calorie restriction and physical activity have an impact on gut microbial composition related to body weight loss, which also seen to be influenced by the individual's microbiota
\end{abstract}




\section{INTRODUCTION}

Obesity is viewed as one of the major current public-health problems and its impact is highest in children, contributing to significant morbidity in adulthood (1). The development of metabolic complications, associated with obesity during childhood, has repercussions in adulthood, increasing the risk of type-2 diabetes and premature cardiovascular diseases (2). A link is thought to exist between obesity, chronic low-grade inflammation, insulin resistance and endothelial dysfunction $(3,4)$. The risk factors for childhood obesity include diet, low socioeconomic status, parental obesity, rapid infancy weight gain, and decreased physical activity (5). Obesity prevention programs based on changes in school and community environments can decrease childhood weight gain to a limited extent (5). Therefore, further studies on dietary and host factors with an impact on energy balance are needed to improve the intervention strategies and measures for obesity control over time.

Recent reports have suggested that gut microbiota is an important factor affecting energy disposal and storage in adipocytes $(6,7)$. The gut microbiota is also known to be involved in modulation of host immunity, and the inflammatory status associated with obesity in mice $(8,9)$. However, the precise mechanisms by which alterations in microbiota affect obesity and associated disorders are still unclear.

It has been reported how diets based on a high protein intake and/or low carbohydrate intake, or high fat intake may alter microbial composition 
and activity in the large intestine and thus exert an impact on gut health $(6,8-$ 10). Nevertheless, knowledge of the interactions between energy intake and specific microbial populations, and their influence on body weight, are limited to small-scale clinical trials (7). Specific studies in obese adolescents, who represent a high-risk population group, are lacking.

The objective of this work was to determine the influence of a multidisciplinary obesity treatment program, comprising a calorie-restricted diet and physical activity, on the structure of the fecal microbiota of overweight and obese adolescents and its relation to dietary intake and weight loss by analyzing the main gut bacterial groups and Bifidobacterium species by quantitative real-time PCR.

\section{METHODS AND PROCEDURES}

\section{Subjects and anthropometric measures}

Subjects for the study were selected according to their BMI (weight $(\mathrm{kg}) /\left(\right.$ height $\left.(\mathrm{m})^{2}\right)$. Childhood overweight (including obesity) was defined according to the International Obesity Task Force cut-offs for BMI (11). BMI z-scores were calculated as a function of the subject's obesity degree when compared with BMI local reference standards (12). Body weight (kg) was estimated without shoes and with light clothing, and measured to $0.05 \mathrm{~kg}$ by using a standard beam balance. Skinfold thicknesses was measured on at the left side of the body to the nearest $0.1 \mathrm{~mm}$ using a Holtain skinfold caliper at 
triceps, biceps, subcapular, suprailiac, thigh, and calf, as previously described (12). All the anthropometric variables were measured in order, three times and averaged. For all the anthropometric measurements, intra-observer reliability was $>95 \%$ and inter-observer reliability was $>90 \%$.

The characteristics of the 36 selected adolescents (18 female and 18 male; mean age: 14.5 years) to be submitted to the obesity-treatment program are shown in Table 1. None of the volunteers were treated with antibiotics for at least 1 month before the intervention study and also, during the study. The study was conducted in accordance with the ethical rules of the Helsinki Declaration (Hong Kong revision, September 1989), following the EEC Good Clinical Practice guidelines (document 111/3976/88 of July 1990) and current Spanish law which regulates clinical research in humans (Royal Decree 561/1993 regarding clinical trials). Informed consent was obtained from all adolescents and their parents, and the study was approved by the local Ethics Committees.

\section{Intervention}

Over a 10-week period, the participants were subjected to the intervention based on an energy-restricted diet (a 10-40\% reduction) established according to both obesity degree and regular physical activity (13). The maximum energy intake was $1,800 \mathrm{kcal} /$ day for females and 2200 $\mathrm{kcal} /$ day for males. The physical activity program was determined by 
Table 1 Clinical characteristics of the studied subjects

\begin{tabular}{lc}
\hline Total subjects & $N=36$ \\
\hline Age (years) & $14.5(13.0-15.0)$ \\
BMI & \\
Before intervention & $32.8(29.4-35.2)$ \\
After intervention & $30.6(27.5-33.3)$ \\
Weight (kg) & \\
Before intervention & $90.5(81.8-102.2)$ \\
After intervention & $84.4(75.3-97.1)$ \\
Weight loss (kg) & $4.7(1.7-7.2)$ \\
Weight loss (\%) & $5.8(2.2-8.6)$ \\
BMl $z$-score & \\
Before intervention & $3.09(2.31-4.08)$ \\
After intervention & $2.71(1.72-3.49)$ \\
\hline Low weight-loss group & $N=13$ \\
\hline Age (years) & $14.5(13.0-15.0)$ \\
BMI & \\
Before intervention & $30.7(26.4-36.3)$ \\
After intervention & $30.2(26.2-35.9)$ \\
Weight (kg) & \\
Before intervention & $85.9(69.4-101.6)$ \\
After intervention & $84.4(68.2-100.7)$ \\
Weight loss (kg) & $1.4(0.75-1.8)$ \\
Weight loss (\%) & $1.3(0.85-2.25)$ \\
BMl z-score & \\
Before intervention & $2.95(1.6-4.03)$ \\
After intervention & $2.74(1.5-3.93)$ \\
\hline
\end{tabular}




\section{Capítulo I}

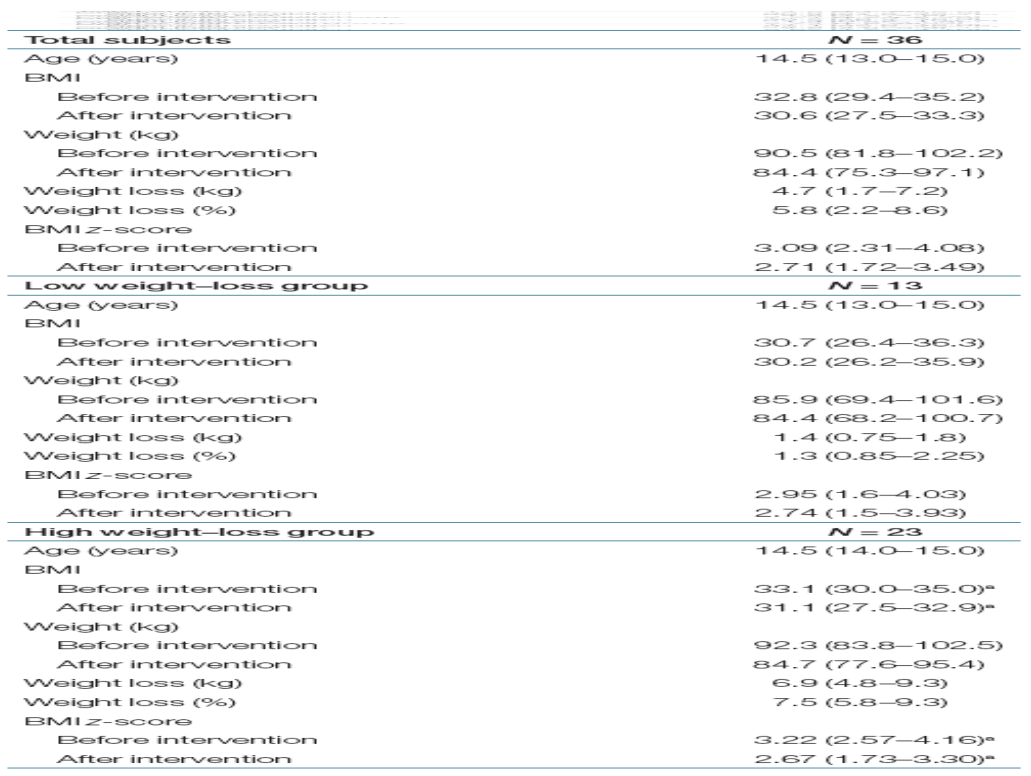

${ }^{a}$ Data are shown as medians and interquartile range (IQR). Statistical differences before and after intervention were calculated by using the Mann-Whitney $U$-test at $P<0.050$.

accelerometry and exercise prescribe at least $1 \mathrm{~h}$ of moderate-to-vigorous intensity 3 or 5 days per week, depending of the individual physical activity level. The energy expenditure was estimated in metabolic equivalent values (14) for each activity and the frequency and intensity of the activities of the exercise program (walking, biking, running, swimming, etc.). The energy expenditure range obtained was from $15-23 \mathrm{kcal} / \mathrm{kg}$ body weight per week. Diet energy content was set from the resting energy expenditure calculated with the Schofield equation multiplied by 1.3 as physical activity factor (13). Energy restriction was calculated in function of the subject obesity degree: $10 \%$ restriction when the subject had a BMI between 0 and 2 s.d. above the mean, 20\% with BMI between 2 to 3 s.d above the mean, 30\% between 3 to 4 s.d. above the mean, $30 \%$ between 3 and 4 s.d., and $40 \%$ if the subject had a 
BMI $>4$ s.d. above the mean according to BMI local reference standards. Macronutrient distribution was 50\% of energy from carbohydrates, $30 \%$ from fat and $20 \%$ from proteins. Energy distribution during the day was: breakfast: $20 \%$ of daily energy; morning snack: $10-15 \%$ of daily energy; lunch: 30-35\% of daily energy; afternoon snack: 5-10\% of daily energy; dinner: 20-25\% of daily energy.

\section{Dietary assessment}

Food diary records were kept for $72 \mathrm{~h}$ ( 2 weekdays and 1 weekend day) both before the start of the study (baseline intakes) and after the intervention (week 10). Detailed information on how to record food and drink consumed using common household measures was provided. Food diary records were returned to their dietician, and analyzed for energy, water and nutrient contents based on the CESNID food-composition database of Spanish foods (14).

\section{Fecal and DNA sample preparation}

Fecal samples were kept immediately after collection at $-20{ }^{\circ} \mathrm{C}$ and stored until analyzed. Samples were diluted 1: 10 (w/v) in PBS ( $\mathrm{pH} 7.2)$, homogenized and one aliquot was used for DNA extraction by using the QIAamp DNA stool Mini kit (Qiagen, Hilden, Germany).

\section{Microbial analysis by quantitative real-time PCR (qPCR)}

Specific primers targeting different bacterial genera and species were used to characterize the fecal microbiota by qPCR (Table 2), essentially as described previously (15-19). Briefly, PCR amplification and detection were 
performed with an ABI PRISM 7000-PCR sequence detection system (Applied Biosystems, Warrington,UK).

Table 2 Oligonucleotide primers used in this study

\begin{tabular}{|c|c|c|c|}
\hline Target bacterial group/species & Sequence $\left(5^{\prime} \leftrightarrow 3\right)$ & $\begin{array}{c}\text { Annealing } \\
\text { temperature }\left({ }^{\circ} \mathrm{C}\right)\end{array}$ & References \\
\hline Total bacteria & TGGCTCAGGACGAACGCTGGCGGC CCTACTGCTGCCTCCCGTAGGAGT & 61 & 16 \\
\hline Bacteroides fragilis group & ATA GCC TाT CGA AAG RAA GAT CCA GTA TCA ACT GCA ATT TTA & 50 & 16,17 \\
\hline Clostridium coccoides group & AAA TGA CGG TAC CTG ACT AA CTT TGA GTT TCA TTC TTG CGA A & 50 & 16,17 \\
\hline Clostridium leptum group & GCA CAA GCA GTG GAG T CTT CCT CCG TIT TGT CAA & 50 & 16,17 \\
\hline Escherichia coli & GTTAATACCTITGCTCATTGAACCAGGGTATCTAATCCTGTT & 62 & 18 \\
\hline Lactobacillus group & GGAAACAG(AVG)TGCTAATACCG CACCGCTACACATGGAG & 61 & 19,20 \\
\hline Bifidobacterium & CTCCTGGAAACGGGTGG GGTGTTCTTCCCGATATCTACA & 55 & 16,17 \\
\hline Bifidobacterium longum & TTCCAGTTGATCGCATGGTC TCSCGCTTGCTCCCCCGAT & 55 & 16,17 \\
\hline Bifidobacterium bifidum & CCACATGATCGCATGTGATTG CCGAAGGCTTGCTCCCAAA & 55 & 16,17 \\
\hline Bifidobacterium breve & CCGGATGCTCCATCACAC ACAAAGTGCCTTGCTCCCT & 55 & 16,17 \\
\hline Bifidobacterium adolescentis & CTCCAGTTGGATGCATGTC TCCAGTTGACCGCATGGT & 55 & 16,17 \\
\hline Bifidobacterium catenulatum group & CGGATGCTCCGACTCCT CGAAGGCTTGCTCCCGAT & 55 & 16,17 \\
\hline
\end{tabular}

Each reaction mixture of $25 \mu \mathrm{L}$ was composed of SYBR ${ }^{\circ}$ Green PCR Master Mix (SuperArray Bioscience Corporation, Foster City, CA), $1 \mu \mathrm{L}$ of each of the specific primers at a concentration of $0.25 \mu \mathrm{mol} / \mathrm{ml}$, and $1 \mu \mathrm{L}$ of template DNA. Bacterial concentration from each sample was calculated by comparing the $\mathrm{Ct}$ values obtained from the standard curves. Standard curves were created using serial tenfold dilution of pure cultures of DNA, corresponding to $10^{2}$ to $10^{9}$ cells from the culture collection as determined by microscopy counts using 4',6-diamidino-2-phenylindole. The following strains were used as references: Bacteroides fragilis DSMZ 2451, Clostridium coccoides DSMZ 933, C. leptum DSMZ 935, Lactobacillus casei ATCC 393, E. coli CECT 45, Bifidobacterium longum subsp. longum CECT 4503, B. bifidum LMG 11041, B. breve LMG 11042, B. pseudocatenulatum CECT 
5776, B. adolescentis LMG 11037. The strains were obtained from the Spanish Collection of Type Cultures (CECT) and the German Collection of Microorganisms and Cell Cultures (DSMZ).

\section{Statistical analyses}

Statistical analyses were done using the SPSS 11.0 software (SPSS Inc, Chicago, IL). Due to non-normal distribution, microbial data are expressed as medians with interquartile ranges (IQRs) and differences in bacterial populations were determined by applying the Mann-Whitney $U$-test and the Wilcoxon signed-rank test. Correlations among variables were calculated by using the Spearman's correlation test. Differences in clinical and anthropometric data were also determined by applying the Mann-Whitney $U$ test. Dietary composition (means and standard deviations) was calculated for crude (unadjusted) nutrients from the $72 \mathrm{~h}$ dietary registers and data were averaged for the analysis. All dietary variables submitted to log-transformation showed fit normal distribution. Repeated-measures ANOVA adjusted for sex and age was used to examine differences in group mean intake before (baseline) vs. after the intervention. In every case, $P$-values $<0.050$ were considered statistically significant. 


\section{RESULTS}

\section{Subjects and obesity intervention program}

The studied subjects, $50 \%$ female (18/36) and $50 \%$ male (18/36), were 14.5 years old (13.0-15.0 years), and maintained an apparently good health status during the study. Clinic and anthropometric characteristics did not differ significantly among subjects at recruitment time particularly regarding weight ( $P=0.266)$, BMI $(P=0.221)$ and BMI-z-score $(\mathrm{P}=0.138)$ and, therefore, they were comparable (Table 1). The subjects showed marked differences in weight loss after intervention and, accordingly, subdivided into two groups as low weight-loss group $(<2.0 \mathrm{~kg}$ of weight loss, $\mathrm{n}=13)$ and high weight-loss group $(>4.0 \mathrm{~kg}$ of weight loss after intervention, $\mathrm{n}=23$ ). The median of weight loss after 10 weeks under the intervention program for the first group was of 1.4 $(0.75-2.00) \mathrm{kg}$, corresponding to $1.3 \%$ (IQR $0.85-2.25 \%$ ) of body weight. This group did not showed significant differences in $\mathrm{BMI}(\mathrm{P}=0.545)$ weight $(\mathrm{P}=0.801)$, and BMI $\mathrm{z}$-score $(P=0.579)$ before and after the dietary intervention. In the second group, the median of weight loss after 10 weeks under the intervention program was of $6.8(4.8-9.0) \mathrm{kg}$, corresponding to $7.5 \%$ (IQR 5.8-9.3\%) of body weight, without detecting significant differences between male $(P=0.204)$ and female $(P=0.083)$. In this group significant differences in BMI $(P=0.030)$ and BMI z-score $(P=0.035)$ were detected before and after the intervention.

Dietary data before and after the intervention of the low weight and high weight-loss groups are shown in Table 3. No interaction between time 
(before and after intervention) per sex or age-group was observed. No significant differences in dietary intake of energy, macronutrients, or on food groups level were found between groups before and after the intervention program. The consumption of probiotic foods i.e., yogurt was almost one portion per day (0.9 portion in both groups, one portion in Spain is equivalent to $125 \mathrm{~g}$ ). None of the subjects consumed pre- or probiotics as supplements. The main sourceof carbohydrates in order of increasing intakes per day were cereal, potatoes, fruits, and diary products. The main fiber sources of this population were vegetables, cereals, fruits and legumes.

In both adolescent groups, the dietary intervention mainly resulted in a significant reduction $(P<0.05)$ in intake of total energy $(63.8 \%$ mean reduction; s.d. 1.2) and macronutrients including proteins (74.5\% mean reduction, s.d. 27.2), fat (51.8\% mean reduction; SD 3.8), polyunsaturated fatty acids (PUFA) (48.7\% mean reduction, s.d. 12.5), carbohydrates $(71.6 \%$ mean reduction, SD 3.9), simple carbohydrates (73.3\% mean reduction; s.d. 0.8), and complex carbohydrates (70.6\% mean reduction; s.d. 7.2). The reduction in complex carbohydrate intake was significantly and negatively correlated $(\mathrm{R}=-0.334 ; P=0.050)$ to changes in $B$. fragilis group as a result of the intervention. Likewise, reduction in PUFA intake was almost significantly and negatively correlated $(\mathrm{R}=-0.313, P=0.063)$ to changes in Lactobacillus group counts. 
Table 3 Daily energy and nutrient intake before (baseline) and after the intervention.

\begin{tabular}{|c|c|c|c|c|c|c|c|c|}
\hline & \multicolumn{4}{|c|}{ Low weight-loss group (>2.0kg) } & \multicolumn{4}{|c|}{ High weight-loss group (>4.0kg) } \\
\hline & \multicolumn{2}{|c|}{$\begin{array}{l}\text { Before intervention } \\
\qquad(n=13)\end{array}$} & \multicolumn{2}{|c|}{$\begin{array}{l}\text { After intervention } \\
\quad(n=13)\end{array}$} & \multicolumn{2}{|c|}{$\begin{array}{l}\text { Before intervention } \\
\qquad(n=23)\end{array}$} & \multicolumn{2}{|c|}{$\begin{array}{l}\text { After intervention } \\
\qquad(n=23)\end{array}$} \\
\hline & Mean & s.d. & Mean & s.d. & Mean & s.d. & Mean & s.d. \\
\hline Energy (kcal) $)^{a, b}$ & $2,121.67$ & 617.00 & $1,428.55$ & 216.83 & $2,377.62$ & 617.56 & $1,460.62$ & 376.52 \\
\hline Water $(g)^{a}$ & $1,325.40$ & 377.84 & $1,109.62$ & 290.99 & $1,912.94$ & 657.90 & $1,999.0$ & 708.51 \\
\hline Protein $(g)^{a, b}$ & 101.30 & 23.47 & 75.59 & 11.66 & 109.82 & 29.92 & 77.04 & 19.56 \\
\hline Energy from protein (\%) & 18.90 & 3.08 & 22.58 & 2.59 & 18.62 & 3.34 & 21.96 & 2.40 \\
\hline Plant protein $(g)^{a, b}$ & 29.28 & 8.13 & 20.58 & 4.26 & 26.37 & 7.88 & 22.44 & 6.97 \\
\hline Plant protein (\%) & 5.58 & 2.06 & 5.64 & 1.25 & 5.31 & 1.89 & 6.38 & 1.26 \\
\hline Animal protein $(g)^{b}$ & 72.32 & 22.55 & 54.10 & 9.97 & 76.56 & 28.67 & 54.67 & 15.37 \\
\hline Animal protein (\%) & 12.80 & 3.11 & 16.21 & 2.41 & 13.43 & 6.54 & 15.77 & 2.37 \\
\hline Fat $(\mathrm{g})^{\mathrm{a}, \mathrm{b}}$ & 91.66 & 45.82 & 51 & 16.32 & 99.39 & 38.25 & 52.11 & 17.66 \\
\hline Energy from fat $(\%)^{b}$ & 38.11 & 9.25 & 34.43 & 8.20 & 40.44 & 5.55 & 31.85 & 5.41 \\
\hline Saturated fat $(g)^{a, b}$ & 26.96 & 18.06 & 17.93 & 4.69 & 36.37 & 15.73 & 15.44 & 6.50 \\
\hline Energy from saturated fat $(\%)^{\mathrm{b}}$ & 11.67 & 3.70 & 10.96 & 2.34 & 13.30 & 3.20 & 9.58 & 2.18 \\
\hline MUFAs $(g)^{a, b}$ & 42.41 & 22.59 & 22.96 & 9.76 & 42.05 & 16.38 & 21.94 & 9.14 \\
\hline Energy from MUFAs (\%) ${ }^{b}$ & 17.65 & 6.27 & 15.52 & 5.72 & 16.62 & 3.35 & 13.45 & 3.68 \\
\hline PUFAs (g) $)^{a, b}$ & 13.22 & 6.35 & 7.03 & 3.64 & 16.82 & 8.01 & 7.25 & 2.47 \\
\hline Energy from PUFAs (\%) ${ }^{\mathrm{b}}$ & 5.77 & 1.25 & 4.91 & 1.71 & 6.82 & 2.40 & 4.25 & 0.93 \\
\hline Cholesterol (mg) $)^{\mathrm{a}, \mathrm{b}}$ & 332.01 & 114.01 & 257.97 & 67.94 & 371.80 & 165.12 & 215.16 & 118.79 \\
\hline $\mathrm{CH}(\mathrm{g})^{\mathrm{a}, \mathrm{b}}$ & 223.03 & 55.40 & 153.71 & 33.32 & 226.29 & 63.37 & 163.63 & 48.75 \\
\hline Energy from $\mathrm{CH}(\%)^{\mathrm{b}}$ & 43.30 & 8.36 & 45.03 & 7.38 & 41.89 & 5.62 & 47.28 & 5.07 \\
\hline Simple CH (g)a,b & 99.85 & 32.80 & 61.99 & 27.63 & 108.36 & 43.83 & 80.91 & 20.37 \\
\hline Energy from simple $\mathrm{CH}(\%)^{b}$ & 16.54 & 6.32 & 21.23 & 7.35 & 18.23 & 5.17 & 22.86 & 6.10 \\
\hline Complex CH (g) $)^{a, b}$ & 114.63 & 38.16 & 74.17 & 21.33 & 114.80 & 32.94 & 81.60 & 36.73 \\
\hline Energy from complex $\mathrm{CH}(\%)$ & 23.88 & 5.77 & 24.6 & 5.54 & 21.29 & 13.61 & 23.96 & 5.34 \\
\hline Dietary fiber (g) & 18.31 & 7.78 & 17.9 & 4.63 & 17.47 & 7.60 & 21.38 & 7.66 \\
\hline
\end{tabular}

$\mathrm{CH}$, carbohydrates; MUFA, Monounsaturated fatty acids; PUFA, Polyunsaturated fatty acids ${ }^{\text {a }}$ Significant $(\mathrm{P}<0.050)$ difference within the low-weight loss group between baseline and after the intervention,

${ }^{\mathrm{b} S i g n i f i c a n t}$ difference within the high weight-loss group (based on age and sex adjusted ANOVA for repeated measurements of log-transformed dietary data).

\section{Influence of intervention in fecal bacterial group composition}

Interindividual differences on fecal microbiota composition for all studied adolescents were 0.77 (IQR 0.39-1.70) for B.fragilis group, -0.36 (IQR -0.82 to 0.29 ) for Bifidobacterium, -0.65 (IQR -0.98 to 0.27 ) for C.coccoides 
group, 0.02 (IQR -0.50 to 0.45 ) for C.leptum group, 0.10 (IQR -0.38 to 0.49 ) for E.coli, and 0.43 (IQR 0.09-0.83) for Lactobacillus group.

The intervention in whole adolescents population $(n=36)$ resulted in increased counts of $B$. fragilis group $(P=0.001)$ and Lactobacillus group $(P=0.030)$ and decreased counts of $C$. coccoides $(P=0.028)$. No significant differences were found in the other bacterial groups analyzed. B. fragilis group $(R=0.55, \mathrm{P}<0.001)$ and C.leptum group $(\mathrm{R}=0.52, \mathrm{P}<0.001)$ counts after the intervention significantly correlated with higher weight loss $(\mathrm{kg})$, while the opposite correlation were found for the E.coli $(\mathrm{R}=-0.26, \mathrm{P}=0.025)$, C.coccoides group $(\mathrm{R}=-0.61, \mathrm{P}<0.001)$, Lactobacillus group $(\mathrm{R}=-0.40, \quad \mathrm{P}=0.001)$, and Bifidobacterium $(\mathrm{R}=-0.37, \mathrm{P}=-0.001)$ counts.

Changes in bacterial counts as a result of intervention were also evaluated by considering separately the high and the low weight-loss groups (Tables 4 and 5). Significant differences were not found in any of the analyzed groups before and after intervention in the low weight-loss group ( $\mathrm{n}=13$ and $<2.0 \mathrm{~kg}$ of weight loss Table 4), while significant differences were found in the high weight-loss group ( $\mathrm{n}=23$ and $>4.0 \mathrm{~kg}$ of weight loss Table 5). In this last group, B. fragilis group and Lactobacillus counts significantly increased ( $P=0.001$ and $P=0.007$, respectively), while those of the $C$. coccoides group significantly decreased $(P=0.001)$ after 10 weeks of intervention. Moreover, the ratio of Bifidobacterium to Clostridium group counts increased significantly after the intervention $(P=0.022)$ when compared to the ratio 
recorded beforehand, while the ratio of Bifidobacterium to B. fragilis counts decreased $(P=0.001)$.

Table 4 Bacterial counts in fecal samples of low weight-loss $(<2.0 \mathrm{~kg})$ group of adolescents before and after intervention

\begin{tabular}{|c|c|c|c|c|c|c|c|c|c|}
\hline \multirow[b]{3}{*}{ Bacterial group } & \multicolumn{8}{|c|}{ Bacterial counts ${ }^{a}(\log$ cells/g fecal sample), $n=13$} & \multirow{3}{*}{$\begin{array}{c}\begin{array}{c}\text { Mann-Whitney } \\
U \text {-test }\end{array} \\
P \text { value }\end{array}$} \\
\hline & \multicolumn{4}{|c|}{ Before intervention } & \multicolumn{4}{|c|}{ After intervention } & \\
\hline & $\operatorname{Prb}$ & Mean & Median & IQR & $\mathrm{Pr}^{\mathrm{b}}$ & Mean & Median & IQR & \\
\hline Total bacteria & 13 & 13.2 & 12.9 & $12.8-13.9$ & 13 & 13.2 & 13.1 & $12.8-13.4$ & 0.975 \\
\hline Bacteroides fragilis & 13 & 6.2 & 6.2 & $5.8-7.0$ & 13 & 6.3 & 6.2 & $5.8-6.9$ & 0.957 \\
\hline Clostridium coccoides & 13 & 10.0 & 10.0 & $9.8-10.2$ & 13 & 9.9 & 10.0 & $9.7-10.2$ & 0.978 \\
\hline Clostridium leptum & 13 & 8.2 & 8.0 & $7.9-8.5$ & 13 & 8.4 & 8.3 & $7.9-8.8$ & 0.446 \\
\hline Lactobacillus & 13 & 7.9 & 7.8 & $7.6-8.1$ & 13 & 7.9 & 7.9 & $7.7-8.1$ & 0.723 \\
\hline Escherichia coli & 13 & 6.7 & 6.5 & $6.0-7.7$ & 13 & 6.6 & 6.5 & $6.0-7.1$ & 0.624 \\
\hline Bifidobacterium & 13 & 9.2 & 9.2 & $8.8-9.5$ & 13 & 8.9 & 9.0 & $8.4-9.6$ & 0.514 \\
\hline Bifidobacterium longum & 13 & 7.1 & 7.0 & $6.8-7.4$ & 13 & 7.0 & 6.9 & $6.3-7.7$ & 0.644 \\
\hline Bifidobacterium breve & 13 & 4.8 & 4.8 & $4.4-5.2$ & 13 & 4.5 & 4.5 & $4.3-4.7$ & 0.110 \\
\hline Bifidobacterium bifidum & 13 & 9.1 & 9.0 & $8.8-9.4$ & 13 & 8.9 & 8.9 & $8.3-9.7$ & 0.640 \\
\hline Bifidobacterium adolescentis & 13 & 8.1 & 8.0 & $7.8-8.4$ & 13 & 8.0 & 7.9 & $7.3-8.7$ & 0.650 \\
\hline Bifidobacterium catenulatum & 13 & 5.8 & 5.8 & $5.5-6.2$ & 13 & 5.5 & 5.5 & $5.3-5.7$ & 0.103 \\
\hline
\end{tabular}

Data are shown as medians and interquartile range (IQR) of cell number per gram of fecal samples. ${ }^{b}$ Prevalence $(\mathrm{Pr})$ reflects the number of positive amplifications by quantitative real -time PCR from total samples $(n=13)$.*Statical differences between bacterial counts before and after intervention were calculated by using the MannWhitney U-test and established at $\mathrm{P}<0.050$

When subjects of high weight-loss group were classified according to gender, certain significant differences were found between the two groups. In females, $B$. fragilis group significantly increased $(P=0.002)$ after the intervention while $C$. coccoides counts decreased $(P=0.023)$, which was in accordance with the results obtained when considering the total high weight-loss group of adolescents. 
Table 5 Bacterial counts in fecal samples of high weight-loss $(>4.0 \mathrm{~kg})$ group of adolescents before and after intervention

\begin{tabular}{|c|c|c|c|c|c|c|c|c|c|}
\hline \multirow[b]{3}{*}{ Bacterial group } & \multicolumn{8}{|c|}{ Bacterial counts ${ }^{\mathrm{a}}$ (log cells/g fecal sample), $n=23$} & \multirow{3}{*}{$\begin{array}{c}\begin{array}{c}\text { Mann-Whitney } \\
U \text {-test }\end{array} \\
P \text { value }\end{array}$} \\
\hline & \multicolumn{4}{|c|}{ Before intervention } & \multicolumn{4}{|c|}{ After intervention } & \\
\hline & $\mathrm{Pr}^{\mathrm{b}}$ & Mean & Median & IQR & $\operatorname{Pr}$ & Mean & Median & IQR & \\
\hline Total bacteria & 23 & 14.8 & 14.6 & $14.0-15.6$ & 23 & 14.5 & 14.8 & $13.1-16.1$ & 0.450 \\
\hline Bacteroides fragilis & 23 & 7.5 & 7.6 & $6.7-8.2$ & 23 & 8.6 & 8.6 & $8.1-9.3$ & $0.001^{*}$ \\
\hline Clostridium coccoides & 23 & 8.7 & 8.6 & $8.3-9.0$ & 23 & 7.9 & 7.7 & $7.4-8.5$ & $0.001^{*}$ \\
\hline Clostridium leptum & 23 & 9.5 & 9.6 & $8.7-9.9$ & 21 & 9.5 & 9.7 & $9.1-10.0$ & 0.666 \\
\hline Lactobacillus & 23 & 6.4 & 6.4 & $5.9-6.9$ & 23 & 6.9 & 7.0 & $6.3-7.1$ & $0.007^{\star}$ \\
\hline Escherichia coli & 23 & 6.3 & 6.3 & $5.8-6.8$ & 23 & 6.4 & 6.3 & $6.1-7.0$ & 0.231 \\
\hline Bifidobacterium & 23 & 8.3 & 8.1 & $7.7-8.6$ & 23 & 8.2 & 8.2 & 7.4-8.6 & 0.692 \\
\hline Bifidobacterium longum & 23 & 7.1 & 7.2 & $6.3-7.9$ & 23 & 6.4 & 6.2 & $5.3-7.3$ & $0.044^{*}$ \\
\hline Bifidobacterium breve & 15 & 3.5 & 3.3 & $3.0-3.6$ & 11 & 3.2 & 3.1 & 3.0-3.5 & 0.237 \\
\hline Bifidobacterium bifidum & 19 & 5.9 & 5.6 & $4.5-7.1$ & 17 & 5.6 & 5.6 & 4.3-7.1 & 0.490 \\
\hline Bifidobacterium adolescentis & 23 & 7.6 & 7.9 & $6.8-8.8$ & 23 & 6.9 & 7.0 & $6.0-8.1$ & 0.082 \\
\hline Bifidobacterium catenulatum & 22 & 7.6 & 7.7 & $6.7-8.5$ & 23 & 7.2 & 7.6 & 6.3-8.4 & 0.594 \\
\hline
\end{tabular}

${ }^{a}$ Data are shown as medians and interquartile range (IQR) of cell number per gram of fecal samples. 'Prevalence (Pr) reflects the number of positive amplifications by quantitative real -time PCR from total samples $(\mathrm{n}=23)$.*Statical differences between bacterial counts before and after intervention were calculated by using the MannWhitney U-test and established at $\mathrm{P}<0.050$

Lactobacillus group increased but the differences were not statistically significant. In males, Lactobacillus and $B$. fragilis groups increased significantly $(P=0.001$ and $P=0.033$, respectively) after the intervention, whereas a significant $(P=0.007)$ reduction was found in the $C$. coccoides group, as was detected for the total high weight-loss group of adolescents.

Significant correlations between bacterial counts after the intervention and weight loss were found in the high weight-loss group (Figure 1). Increased levels of B.fragilis group $(\mathrm{R}=0.27, P=0.055)$ and Lactobacillus significantly correlated $(\mathrm{R}=0.55, P<0.001)$ with weight loss $(\mathrm{kg})$, while the 
opposite correlation $(\mathrm{R}=-0.37, P=0.010)$ was found for the $E$. coli group (Figure 1). Similar correlations were recorded between Lactobacilllus $(\mathrm{R}=$ 0.53, $P=0.008)$ and B.fragilis group $(\mathrm{R}=0.44, P=0.036)$ levels, and body weight-loss percentages. The reductions in BMI $z$-scores as a result of the intervention were also significantly correlated with increased levels of Lactobacillus group $(\mathrm{R}=0.62, P=0.001)$ and $B$ fragilis group $(\mathrm{R}=0.46, P=$ 0.025). Reduced $C$. coccoides group levels were related to weight loss, $(\mathrm{R}=-$ 0.611, $\mathrm{P}=0.001)$. The correlation between the reduction in Bifidobacterium to C.coccoides group ratio and weight loss was significantly $(\mathrm{R}=-0.25, P=0.030$, as well as the correlation between the reduction in Bifidobacterium to B. fragilis group ratio and weight loss a result of the intervention to weight loss was also almost significantly $(\mathrm{R}=-0.62, P<0.001)$ as a result of the intervention.
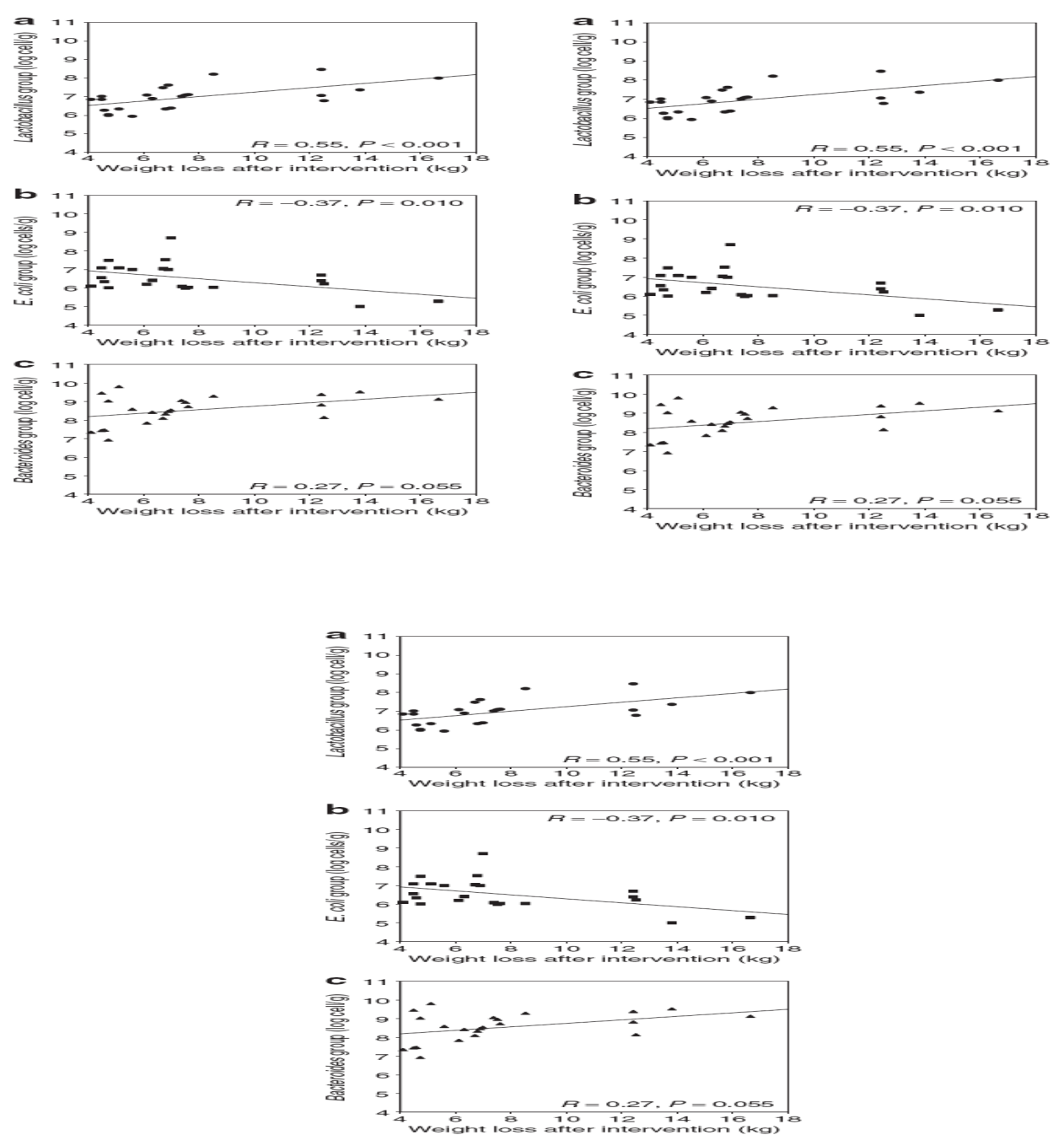
Figure 1 Correlations between fecal bacterial counts and weight loss after intervention in the high weight-loss group ( $\mathrm{n}=23 ;>4.0 \mathrm{~kg}$ weight loss) of adolescents. Lines showed the Pearson correlation (liner adjustment). (a) Lactobacillus group vs weight loss, (b) Escherichia coli vs weight loss, and (c) Bacteroides fragilis group vs weight loss

No significant differences were found in the other Bifidobacterium species analyzed. B. breve $(\mathrm{R}=-0.55, P$-value $<0.001)$, and $B$. bifidum $(\mathrm{R}=-$ 
$0.69, P$-value $<0.001)$ counts after the intervention significantly correlated correlated with lower weight loss $(\mathrm{kg})$, while no correlations were found in the other species. Changes in Bifidobacterium species counts as a result of the intervention were also evaluated by considering separately the high and the low weight-loss groups (Table 4 and 5).

Bifidobacterium species counts showed significant differences as a result of the intervention in the high weight-loss group (table 5), while not in the low weight-loss group of adolescents (table 4). In the high weight-loss group, all Bifidobacterium species analyzed decreased after the dietary intervention, although only the changes in B. longum counts were significant $(P=0.044)$. Similar trends were found when comparing Bifidobacterium species composition in males or females. However only B. adolescentis counts decreased significantly after intervention $(P=0.037)$ in males, whereas no significant differences were found in females. Significant correlations were not detected between Bifidobacterium species counts and either weight loss, BMI, or BMI z-score.

\section{Differences in fecal microbiota composition between the low weight-loss} and high weight-loss groups of adolescents

The differences in fecal microbiota composition between low and high weight-loss groups of adolescents before and after the intervention are shown in Table 6. Before the intervention, total bacteria, B.fragilis group and $C$. leptum counts were significantly higher $(\mathrm{P}<0.001, P=0.004$ and $P<0.001$, respectively), while those of $C$. coccoides group, Lactobacillus group and 
Bifidobacterium were significantly lower $(P<0.001, P<0.001$ and $P=0.001$, respectively) in the high weight-loss group than in the low weight-loss group. The ratio of B.fragilis group to $C$. coccoides was also significantly higher $(P<$ 0.001) in the high weight-loss group. The same trend was detected for Bifidobacterium to $C$. coccoides ratio but the differences were not significant $(P=0.140)$. After 10 weeks of intervention, similar differences on microbiota were found between the low weight and the high weight-loss groups. Total bacteria, B.fragilis group and C. leptum counts were significantly higher ( $P=0.015, P=0.001$ and $P<0.001$, respectively) while counts of the $C$. coccoides group, Lactobacillus group and Bifidobacterium were significantly lower ( $P<0.001, P<0.001$ and $P=0.008$, respectively) in the high weight-loss than in the low weight-loss group. In addition, $B$. fragilis group, Bifidobacterium and Lactobacillus group to $C$. coccoides group ratios were significantly higher ( $P<0.001, P<0.001$ and $P=0.034$, respectively) in the high weight-loss than in the low weight-loss group.

In relation to Bifidobacterium species composition, $B$. breve and $B$. bifidum group counts were significantly higher in the low weight-loss than in the high weight-loss group before $(P=0.001$ and $P<0.001$, respectively) and after intervention $(P<0.001$ for both groups) whereas Bifudobacterium catenulatum group levels were higher in high weightloss group $(P=0.030$ and $P=0.036$, before and after intervention, respectively).

Table 6. Bacterial counts in fecal samples of low and high-weigth-loss groups of adolescents, before and after intervention. 


\begin{tabular}{|c|c|c|c|c|c|c|c|c|c|}
\hline \multirow[b]{2}{*}{ Bacterial group } & \multicolumn{4}{|c|}{$\begin{array}{l}\text { Low weight-loss group }(<2.0 \mathrm{~kg}) \\
\qquad(n=13)\end{array}$} & \multicolumn{4}{|c|}{$\begin{array}{l}\text { High weight-loss group (>4.0 kg) } \\
\qquad(n=23)\end{array}$} & \multirow{2}{*}{$\begin{array}{c}\begin{array}{c}\text { Mann-Whitney } \\
U \text {-test }\end{array} \\
P \text { value }\end{array}$} \\
\hline & $\mathrm{Pr}^{\mathrm{a}}$ & Mean & Median & IQR & $\operatorname{Pr}$ & Mean & Median & IQR & \\
\hline \multicolumn{10}{|c|}{ Bacterial counts ${ }^{\mathrm{b}}$ before intervention (log cells/g fecal sample) } \\
\hline Total bacteria & 13 & 13.2 & 12.9 & $12.8-13.9$ & 23 & 14.8 & 14.6 & $14.0-15.6$ & $<0.001^{*}$ \\
\hline Bacteroides fragilis & 13 & 6.2 & 6.2 & $5.8-7.0$ & 23 & 7.5 & 7.6 & $6.7-8.2$ & $0.004^{*}$ \\
\hline Clostridium coccoides & 13 & 10.0 & 10.0 & $9.8-10.2$ & 23 & 8.7 & 8.6 & $8.3-9.0$ & $<0.001^{*}$ \\
\hline Clostridium leptum & 13 & 8.2 & 8.0 & $7.9-8.5$ & 23 & 9.5 & 9.6 & $8.7-9.9$ & $<0.001^{*}$ \\
\hline Lactobacillus & 13 & 7.9 & 7.8 & $7.6-8.1$ & 23 & 6.4 & 6.4 & $5.9-6.9$ & $<0.001^{*}$ \\
\hline Escherichia coli & 13 & 6.7 & 6.5 & $6.0-7.7$ & 23 & 6.3 & 6.3 & $5.8-6.8$ & 0.123 \\
\hline Bifidobacterium & 13 & 9.2 & 9.2 & $8.8-9.5$ & 23 & 8.3 & 8.1 & $7.7-8.6$ & $0.001^{*}$ \\
\hline Bifidobacterium longum & 13 & 7.1 & 7.0 & $6.8-7.4$ & 23 & 7.1 & 7.2 & $6.3-7.9$ & 0.845 \\
\hline Bifidobacterium breve & 13 & 4.8 & 4.8 & $4.4-5.2$ & 15 & 3.5 & 3.3 & $3.0-3.6$ & $0.001^{*}$ \\
\hline Bifidobacterium bifidum & 13 & 9.1 & 9.0 & $8.8-9.4$ & 19 & 5.9 & 5.6 & $4.5-7.1$ & $<0.001^{*}$ \\
\hline Bifidobacterium adolescentis & 13 & 8.1 & 8.0 & $7.8-8.4$ & 23 & 7.6 & 7.9 & $6.8-8.8$ & 0.468 \\
\hline Bifidobacterium catenulatum & 13 & 5.8 & 5.8 & $5.5-6.2$ & 22 & 7.6 & 7.7 & $6.7-8.5$ & $0.030^{*}$ \\
\hline \multicolumn{10}{|c|}{ Bacterial counts ${ }^{b}$ after intervention (log cells/g fecal sample) } \\
\hline Total bacteria & 13 & 13.2 & 13.1 & $12.8-13.4$ & 23 & 14.5 & 14.8 & $13.1-16.1$ & $0.015^{\star}$ \\
\hline Bacteroides fragilis & 13 & 6.3 & 6.2 & $5.8-6.9$ & 23 & $8.6^{*}$ & 8.6 & $8.1-9.3$ & $0.001^{*}$ \\
\hline C. coccoides & 13 & 9.9 & 10.0 & $9.7-10.2$ & 23 & $7.9^{*}$ & 7.7 & $7.4-8.5$ & $<0.001^{*}$ \\
\hline C. leptum & 13 & 8.4 & 8.3 & $7.9-8.8$ & 21 & 9.5 & 9.7 & $9.1-10.0$ & $<0.001^{*}$ \\
\hline Lactobacillus & 13 & 7.9 & 7.9 & $7.7-8.1$ & 23 & $6.9^{*}$ & 7.0 & $6.3-7.1$ & $<0.001^{*}$ \\
\hline E. coli & 13 & 6.6 & 6.5 & $6.0-7.1$ & 23 & 6.4 & 6.3 & $6.1-7.0$ & 0.972 \\
\hline Bifidobacterium & 13 & 8.9 & 9.0 & $8.4-9.6$ & 23 & 8.2 & 8.2 & $7.4-8.6$ & $0.008^{*}$ \\
\hline B. longum & 13 & 7.0 & 6.9 & $6.3-7.7$ & 23 & $6.4^{*}$ & 6.2 & $5.3-7.3$ & 0.062 \\
\hline B. breve & 13 & 4.5 & 4.5 & $4.3-4.7$ & 11 & 3.2 & 3.1 & $3.0-3.5$ & $<0.001^{*}$ \\
\hline B. bifidum & 13 & 8.9 & 8.9 & $8.3-9.7$ & 17 & 5.6 & 5.6 & $4.3-7.1$ & $<0.001^{*}$ \\
\hline B. adolescentis & 13 & 8.0 & 7.9 & $7.3-8.7$ & 23 & 6.9 & 7.0 & $6.0-8.1$ & 0.063 \\
\hline B. catenulatum & 13 & 5.5 & 5.5 & $5.3-5.7$ & 23 & 7.2 & 7.6 & $6.3-8.4$ & $0.036^{*}$ \\
\hline
\end{tabular}

${ }^{\text {aPrevalence }}(\mathrm{Pr})$ reflects the number of positive amplifications by quantitative real -time PCR from total samples $(n=13$ or 23$)$.

${ }^{b}$ Data are shown as medians and interquartile range (IQR) of cell number per gram of fecal samples.

* Statical differences between bacterial counts for each group (high-and low weight adolescent groups)before and after intervention were calculated by using the Mann-Whitney Utest and established at $\mathrm{P}<0.050$.

\section{DISCUSSION}


This study shows for the first time that an intervention based on both a reduction in energy intake and an increase in energy expenditure has an important impact on the composition of the gut microbiota of overweight adolescents related to body weight loss. B. fragilis group and Lactobacillus group seem to be the gut bacterial most amenable to dietary intervention on the basis of the relationships established between the shifts of these bacterial counts and complex carbohydrate and PUFA intakes during the intervention. The Bacteroides genus has been shown to have high ability to utilized complex carbohydrates, wich may explain the aforementioned correlation (21). A possible correlation between PUFA intake and Lactobacillus group count reductions was also detected, suggesting that PUFA intake may favor the prevalence of Lactobacillus group in the gut microbiota. In previous studies, PUFAs have been shown to be utilized by Lactobacillus, leading to changes in bacterial fatty acids and suggesting a potential role of Lactobacillus as regulators of PUFA absorption in vivo (22).In addition, PUFAs have positively influenced the adhesion of Lactobacillus to the jejuna mucosa of gnotobiotic piglets, indicating the intake of these fatty acids may influence the intestinal levels of this bacterial group (23).

Nevertheless, the extent to which these bacterial group counts may change and influence weight loss do not seem to depend only on the diet because significant differences in bacterial counts but not in dietary intakes, were detected between the high weight-loss and the low-weight loss groups during the intervention. Thus, these findings suggest that the individual's gut 


\section{Capitulo I}

microbiota is an additional factor contributing together with lifestyle to body weight regulation.

In response to the intervention, levels of the B.fragilis group significantly increased and correlated to weight loss and BMI z-score reductions, while those of the $C$. coccoides group, which comprises the Clostridium cluster XIVa including members of other genera such as Coprococcus, Eubacterium, Lachnospira, and Ruminococcus (17), decreased and correlated to weight loss in the whole adolescent population and the high weight-loss group. These findings were in agreement with the results previously obtained in the same population using fluorescents in situ hybridization technique, which showed that proportions of C. hystolyticum and Eubacterium rectal-C.coccoides groups dropped and those of the Bacteroides Prevotella group increased after the intervention in those adolescents that los $>$ $4 \mathrm{~kg}$ (24). In other studies, the fecal microbiota of obese adult subjects also showed a significant increase in Bacteroidetes and a proportional decrease in Firmicutes (which included Clostridium genus) after following either fat or carbohydrate-restricted low-calorie diet, which led to weight loss over a year (7). Thus, the association between the B.fragilis group and C. coccoides group with energy intake and body weight changes confirmed in this in different short term intervention study by using different molecular detection techniques resembles that previously established with the broad phyla Bacteroidetes and Firmicutes in a human long-term intervention study(7). 
In this study, the ratio of Bifidobacterium to C. coccoides group counts significantly increased as a result of the intervention in the high weight-loss group. A significant reduction of this ratio was also evident in children who developed atopic diseases later, indicating that the relative proportions of these bacterial groups may precede the development of immune-related disorders (25). Thus, a reduction in calorie intake and an increase in energy expenditure may also have a beneficial overall impact on these bacterial populations and their relationship to the proinflammatory status linked to obesity. However, the intervention led to reductions in B. longum group and B. adolescentis counts in the whole adolescent population as well as to reductions in B. longum and B. adolescentis counts in the high weight -loss group and in male of this group respectively. A reduced dietary intake of carbohydrates by obese adult subjects was shown to be associated with reductions in Bifidobacterium counts in previous studies (10), which could also partly explained the reductions of this bacterial groups in the studied adolescents. In fact, genomic and physiological studies have shown that species such a B. longum and B. adolescentis may actively participate in the utilization of complex polysaccharides in the colon (21). In general, beneficial effects have previously been attributed to Bifidobacterium in connection with obesity. In obese mice models fed with a high fat-content diet, increases in Bifidobacterium caused by administering a high fermentable oligosaccharide was positively correlated with the normalization of inflammatory status, improved glucose tolerance and glucoseinduced insulin secretion $(8,9)$. In addition, reductions in Bifidobacterium populations have been shown to precede the development of overweight (26). 
It is likely that relative proportions of Bifidobacterium to other bacterial groups, like those detected in this study in relation to Clostridium, rather than absolute numbers have a meaning in the context of obesity. In general, although some of the reported differences in bacterial counts associated to body weight loss were small, from the biological point of view, these could be important in the long term by themselves and because they may lead to changes in the relative proportions of other intestinal bacteria competing for the same ecological niche, which may exert a mild but sustained effect on energy metabolism.

Interestingly, significant increases in Lactobacillus group counts in the whole adolescent population and in the high weight-loss group were detected after the intervention, in agreement with the trend previously detected by fluorescent in situ hybridization analyses although the differences were not significant (24). In this study, the increase in Lactobacillus group counts was correlated with weight loss and BMI $z$-score reductions in the high weight-loss group, pointing to role for this bacterial group in body-weight management. Until now, information about the impact of different diets on Lactobacillus group levels was scarce. In a recent human study Lactobacillus group levels were not significantly modified after following different diets: high-protein and low-carbohydrate diet or a high-protein and moderate-carbohydrate diet (10). In mice fed with a high fat-content diet no significant differences were found in Lactobacillus group levels as compared to controls $(8,9)$. 
The gut microbiota of adolescents also appeared to be different between subjects showing high weight-loss and low weight-loss during the intervention and, apparently, this feature was not related to significant dietary intakes. The adolescent group, which showed higher counts of total bacteria, B. fragilis group, C. leptum group and B. catenolatum group and lower $C$. coccoides, Lactobacillus, Bifidobacterium and B. breve counts in their fecal microbiota, was the one that experienced the highest weight loss under the intervention. In addition, B. fragilis group, Bifidobacterium and Lactobacillus group to $C$. coccoides group ratios were higher in the high weight-loss group than in the low weight-loss group. Thus, Bacteroides and C. coccoides group counts of the individual's microbiota seems to oppositely influence the ability of the host to loss weight under the same dietary intervention in agreement with the detected correlations between these bacterial groups and weight loss. The opposite influences that seem to exert these bacterial groups on body weight are in agreement with previous reports in obese mice models and in a small-scale trial with adult human subjects (6-7). In this context although increase counts of C.leptum group which includes certain members of genera Clostridium, Ruminicoccus, Eubacterium and Faecalibacterium that belong to Clostridium cluster IV (17), also seemed to favor weight loss, this trend was not confirmed when comparing the bacterial counts of this group before and after the intervention in the high weight-loss group. In addition reduced B.bifidum and B.breve counts and increased B.catenulatum counts seemed to favor weigh loss, but these trends were not confirmed by the changes detected before and after the intervention in the high weight-loss group. Therefore, further studies are needed to draw conclusions about the role of specific 
Bifidobacterium species in obesity and weight management. In addition, the possibility that the low weight-loss group did not respond to the intervention due to failure to comply completely with the diet cannot be completely disregarded, because it is well recognized that obese patients have difficulty to accurately record their own food intake.

In summary, an association of specific bacterial groups with obesity and body weight loss has been reported in adolescents, pointing to a role played by B. fragilis, Lactobacillus and Clostridium groups, as well as by the relative proportions of B. fragilis, Bifidobacterium and Lactobacillus groups to C. coccoides group. The obtained results have also indicated that the interactions between the gut microbiota and body weight may be sensitive to lifestyle intervention to different extent depending on the individual's microbiota structure.

\section{ACKNOWLEDGEMENTS}

This work was supported by grants AGL2005-05788-C02-01 and and Consolider Fun-C-Food CSD2007-00063 from the Spanish Ministry of Science and Innovation and AP 002/07 from Consellería de Sanidad (Valencia, Spain). The EVASYON study was supported by grants from Spanish Ministry of Health (PI051574). The scholarship from CONACYT (México) to A. Santacruz and I3P Postdoctoral Contract from CSIC (Spain) to MC. Collado are fully acknowledged. The EVASYON study Group is also acknowledged. 


\section{References}

1. Owen C, Martin R, Whincup P, Smith D, Cook D. The effect of infant feeding on the risk of obesity across the life course: a quantitative review of published evidence. Pediatrics 2006; 115: 1367-1377.

2. Nathan BM, Moran A. Metabolic complications of obesity in childhood and adolescence: more than just diabetes. Curr Opin Endocrinol Diabetes Obes 2008; 15:21-29.

3. Wärnberg J, Nova E, Moreno LA, et al. Inflammatory proteins are related with total and abdominal adiposity in a healthy adolescent population. The AVENA study. Am J Clin Nutr 2006; 84:505-512.

4. Hotamisligil GS. Inflammation and metabolic disorders. Nature 2006; 14 : 444:860-867.

5. Isganaitis E, Levitsky LL. Preventing childhood obesity: can we do it? Curr Opin Endocrinol Diabetes Obes 2008; 15:1-8.

6. Bäckhed F, Ding H, Wang T, et al. The gut microbiota as an environmental factor that regulates fat storage. Proc Natl Acad Sci 2004; 101:1571815723.

7. Ley RE, Turnbaugh PJ, Klein S, Gordon JI. Microbial ecology: human gut microbes associated with obesity. Nature 2006; 444:1022-1023.

8. Cani PD, Amar J, Iglesias MA, et al. Metabolic endotoxemia initiates obesity and insulin resistance. Diabetes 2007; 56:1761-1772.

9. Cani PD, Neyrinck AM, Fava F, et al. Selective increases of bifidobacteria in gut microflora improve high-fat-diet-induced diabetes in mice through a mechanism associated with endotoxaemia. Diabetologia 2007; 50:2374-2383.

10. Duncan SH, Belenguer A, Holtrop G, Johnstone AM, Flint HJ, Lobley E. Reduced dietary intake of carbohydrates by obese subjects results in decreased concentrations of butyrate and butyrate-producing bacteria in feces. Appl Environ Microbiol 2007; 73:1073-1078.

11. Cole TJ, Bellizzi MC, Flegal KM, Dietz WH. Establishing a standard definition for child overweight and obesity worldwide: international survey. BMJ 2000; 320:1-6.

12. Moreno LA, Mesana MI, González-Gross M, et al. Anthropometric body fat composition reference values in Spanish adolescents. The AVENA Study. Eur J Clin Nutr 2006; 60: 191-196.

13. Rodríguez G, Moreno LA, Sarría A, Fleta J, Bueno M. Resting energy expenditure in children and adolescents: agreement between calorimetry and prediction equations. Clin Nutr 2002; 21:255-260. 
14. Ainsworth BE, Haskell WL, Herrmann SD, Whitt-Glover MC, et all. Compendium of Physical Activities:an update of activity codes and MET intensities. Med Sci Sports Exerc.2000; 32 (9 Suppl): S498-S504

15. Farran A, Zamora R, Cervera P, CESNID. Tablas de composición de alimentos CESNID. $2^{\mathrm{a}}$ ed. Edicions Universitat de Barcelona - McGraw-Hill /Interamericana: Barcelona, 2004.

16. Matsuki T, Watanabe K, Fujimoto J, et al. Development of 16S rRNAgene-targeted group-specific primers for the detection and identification of predominant bacteria in human feces. Appl Environ Microbiol 2002; 68: $5445-5451$.

17. Matsuki T, Watanabe K, Fujimoto J, Takada T, Tanaka R. Use of $16 \mathrm{~S}$ rRNA gene-targeted group-specific primers for real-time PCR analysis of predominant bacteria in human feces. Appl Environ Microbiol 2004;70:72207228.

18. Malinen E, Rinttilä T, Kajander K, et al. Analysis of the fecal microbiota of irritable bowel syndrome patients and healthy controls with real-time PCR. Am J Gastroenterol 2005; 100:373-382.

19. Walter J, Hertel C, Tannock GW, Lis CM, Munro K, Hammes WP. Detection of Lactobacillus, Pediococcus, Leuconostoc, and Weissella species in human feces by using group-specific PCR primers and denaturing gradient gel electrophoresis. Appl Environ Microbiol 2001; 67:2578-2585.

20. Heilig HG, Zoetendal EG, Vaughan EE, Marteau P, Akkermans ADL, de Vos WM: Molecular diversity of Lactobacillus spp. and other lactic acid bacteria in the human intestine as determined by specific amplification of $16 \mathrm{~S}$ ribosomal DNA. Appl Environ Microbiol 2002; 68:114-123.

21. Sanz Y, Santacruz A, De Palma G. Insights into the roles of gut microbes in obesity, Interdiscip Perspect Infect Dis 2008;2008:829101

22. Kankaanpää P, Yang B, Kallio H, Isolauri E, Salminen S. Effects of polyunsaturated fatty acids in growth medium on lipid composition and on physicochemical surface properties of lactobacilli. Appl Environ Microbiol. 2004; 70:129-36.

23. Bomba A, Nemcová R, Gancarcíková S, et al The influence of omega-3 polyunsaturated fatty acids (omega-3 pufa) on lactobacilli adhesion to the intestinal mucosa and on immunity in gnotobiotic piglets.Berl Munch Tierarztl Wochenschr. 2003;116:312-316.

24. Nadal I, Santacruz A, Mancos A, et al. Shifts in clostridia, bacteroides and immuglobulin-coating fecal bacteria associated with weight loss in obese adolescents. Int J Obes (Lond)2008; e-pub ahead of print 9 December 2008. 
25. Kalliomäki M, Kirjavainen P, Eerola E, Kero P, Salminen S, Isolauri E. Distinct patterns of neonatal gut microflora in infants in whom atopy was and was not developing. J Allergy Clin Immunol 2001; 107:129-134.

26. Kalliomäki M, Collado MC, Salminen S, Isolauri E. Early differences in faecal microbiota composition in children may predict later weight-gain?. Am J Clin Nutr 2008; 87: 534-538.

Shifts in clostridia, bacteroides and immunoglobulin-coating faecal bacteria associated with weight loss in obese adolescents

International Journal of Obesity, 2009, 33 (7) , pp. 758-767 


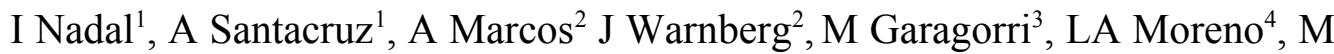
Martin-Matillas ${ }^{5}$, C Campoy ${ }^{5}$, A Martí ${ }^{6}$, A Moleres ${ }^{6}, \mathrm{M} \mathrm{Delgado}^{7}$, OL Veiga ${ }^{8}$, M García-Fuentes ${ }^{9}$, CG Redondo ${ }^{9}$ and Y Sanz ${ }^{1}$

${ }^{1}$ Microbial Ecophysiology. Instituto de Agroquímica y Tecnología de Alimentos (CSIC), Valencia, Spain

${ }^{2}$ Grupo de Inmunonutrición. Instituto del Frío. ICTAN (CSIC), Madrid, Spain.

${ }^{3}$ Departamento de Pediatría, Radiología y Medicina Física, Universidad de Zaragoza, Spain;

${ }^{4}$ E.U. Ciencias de la Salud, Universidad de Zaragoza, Spain;

${ }^{5}$ Facultad de Medicina, Universidad de Granada, Granada, Spain.

${ }^{6}$ Departamento de Fisiología y Nutrición, Universidad de Navarra, Pamplona Spain.

${ }^{7}$ Facultad de Ciencias de la Actividad Física y Deporte; Universidad de Granada, Granada ,Spain.

${ }^{8}$ Departamento de Educación Física, Deporte y Movimiento Humano, Universidad Autónoma de Madrid, Spain.

${ }^{9}$ Departamento de Ciencias Médicas y Quirúrgicas, Universidad de Cantabria, Santander, Spain.

Running title: Gut microbiota associated with weight loss.

\begin{abstract}
To evaluate the effects of a multidisciplinary obesity treatment programme on fecal microbiota composition and immunoglobulin-coating bacteria in overweight and obese adolescents and their relationship to weight loss. Thirtynine overweight and obese adolescents (BMI mean 33.1 range 23.7-50.4; age
\end{abstract}


mean14.8; range 13.0-16.0). BMI, BMI z-scores and plasma biochemical parameters were measured before and after the intervention. Fecal microbiota was analyzed by fluorescent in situ hybridization. Immunoglobulin-coating bacteria were detected using fluorescent-labelled $\mathrm{F}\left(\mathrm{ab}^{\prime}\right) 2$ antihuman $\operatorname{IgA}, \operatorname{IgG}$ and IgM.Reductions in $C$. histolyticum and E. rectale-C. coccoides proportions significantly correlated with weight and BMI z-score reductions in the whole adolescent population. Proportions of C.histolyticum, C.lituseburense and E.rectale-C.coccoides dropped significantly whereas those of the BacteroidesPrevotella group increased after the intervention in those adolescents who lost more than $4 \mathrm{~kg}$. Total fecal energy was almost significantly reduced in the same group of adolescents but not in the group that lost less than $2.5 \mathrm{~kg}$. IgAcoating bacterial proportions also decreased significantly in participants who lost more than $6 \mathrm{~kg}$ after the intervention, paralleled to reductions in $C$. histolyticum and E. rectale-C. coccoides populations. E. rectale-C. coccoides proportions also correlated with weight loss and BMI z-score reduction in participants whose weight loss exceeded $4 \mathrm{~kg}$. Specific gut bacteria and an associated IgA response were related to body weight changes in adolescents under lifestyle intervention. These results suggest interactions between diet, gut microbiota and host metabolism and immunity in obesity. 


\section{INTRODUCTION}

Obesity and the associated metabolic disorders, such as diabetes and metabolic syndrome, have become major public-health issues in adult and paediatric populations worldwide. ${ }^{1-3}$ Obesity results from a positive energy balance and is characterized by a state of chronic, low-grade inflammation with abnormal cytokine and acute-phase inflammatory protein production. ${ }^{4}$ Treatments based on calorie restriction, exercise and behavioural changes have succeeded to some extent to control obesity, but usually yield limited and transient weight loss. ${ }^{5}$ More efficient strategies to control obesity and tackle its metabolic consequences are, therefore, urgently needed. In this context, it is essential to identify interactions between the environmental factors and host mechanisms involved in energy regulation with a view to developing additional intervention strategies. ${ }^{3,6}$

The environmental factors accounting for the dramatic rise in obesity in recent decades are not fully understood. Breastfeeding seems to be a protective factor against obesity later in life, whereas increased energy intake in formula or mixed-fed infants seems to be detrimental. ${ }^{7}$ In recent studies, lack of breastfeeding, high early energy intake and high intake of sugar-sweetened beverages have also been shown to contribute to obesity in adolescents. ${ }^{8}$ In addition, shifts in the composition of gut microbiota in response to dietary factors, such as total quantity and quality of carbohydrate and fat intake, have been reported. ${ }^{9}$ In fact, the microbes populating the gut are currently being investigated as potential environmental factors involved in obesity. ${ }^{6,9,10}$ Gut 
microbiota is viewed as a metabolic organ that plays a pivotal role in the physiology of energy homeostasis. ${ }^{11}$ Commensal bacteria contribute to the digestion of nutrients otherwise inaccessible to humans, such as complex polysaccharides.

The microbial fermentation of undigested dietary compounds in the large intestine can provide up to $10-15 \%$ of human daily energy supply. ${ }^{11}$ Gut microbes are known to be involved in the absorption of monosaccharides and short-chain fatty acids, as well as in their conversion to complex lipids in the liver and their storage in adipocytes. ${ }^{6}$ In addition, commensal bacteria colonizing the gut or in transit may also regulate the signalling pathways that link obesity with inflammation by interacting with the epithelium and host immune system. ${ }^{12}$ So far, some studies associated obesity with an increase in the proportion of Firmicutes and a reduction in Bacteroidetes, in mice obesity models and adult human participants through small-scale intervention studies ${ }^{10}$ but other results were controversial. ${ }^{13}$ In mice fed on a high-fat diet, increases in Bifidobacterium levels achieved by intake of prebiotics were correlated with normalization of inflammatory status and endotoxaemia. ${ }^{12}$ Notable differences in microbiota composition have also been shown between exercised and sedentary rats. ${ }^{14}$ Nevertheless, the associations between specific gut bacteria and human host metabolism and immunity in relation to obesity remain largely uncharacterized.

The objective of this study was to evaluate the effects of a multidisciplinary obesity treatment programme (including energy-restricted 
diet and increased physical activity) on fecal microbial composition and immunoglobulin-coating bacteria in overweight or obese adolescents and assess their relationship to biochemical parameters and weight loss. Thus, stronger links between gut microbes and human obesity can be established.

\section{METHODS}

\section{Participants and experimental design}

Participants for the study were selected according to their body mass index (BMI) [weight $(\mathrm{kg}) /\left[\right.$ height $\left.(\mathrm{m})^{2}\right]$ and classified as overweight or obese according to the International Obesity Task Force criteria defined by Cole et $a l{ }^{1}$ during the course of the EVASYON study. The current study was designed to develop a multidisciplinary obesity-treatment programme adapted to Spanish primary health care centres and was assessed by Paediatric services in five cities around Spain. The treatment programme included nutritional and individual diet counselling, including calorie restriction and increased physical activity, as well as group therapies aim at changing behaviour, providing support and encouraging adolescents to change lifestyle and follow treatment recommendations.

A total of 39 overweight or obese Spanish adolescents (20 females and 19 males; mean age 14.8 years) were included in this study, and their characteristics are shown in Table 1. BMI $z$-scores were calculated as a function of the participant's obesity degree when compared with BMI local reference standards. ${ }^{2}$ Over a 10-week period, the participants followed an 
energy-restricted diet (a 10-40\% reduction) established according to both obesity degree and regular physical activity determined by accelerometry. ${ }^{15}$ The maximum energy intake was $1800 \mathrm{kcal} /$ day for females and $2200 \mathrm{kcal} /$ day for males. The physical activity program was established to increase energy expenditure by $15-23 \mathrm{kcal} / \mathrm{kg}$ body weight per week. None of the volunteers were treated with antibiotics during the study.

Table 1. Clinical characteristics of the studied subjects

\begin{tabular}{|c|c|c|}
\hline Characteristics $^{\mathrm{a}}$ & Total subjects $\mathrm{n}=39$ & \\
\hline Age (years) & $14.4(13.0-16.0)$ & \\
\hline Diet (kcal day $\left.{ }^{-1}\right)$ & $1762(1300-2200)$ & \\
\hline \multirow{3}{*}{$\begin{array}{l}\text { Weight loss (kg) } \\
\text { Energetic expenditure per } \\
\text { week }\end{array}$} & $4.3(0.8-16.7)$ & \\
\hline & $\begin{array}{c}15-23 \mathrm{kcal} \mathrm{kg}^{-1} \text { body } \\
\text { weight }\end{array}$ & \\
\hline & Before intervention & After intervention \\
\hline BW (kg) & $91.7(62.0-145.0)$ & $87.4(62.8-131.2)$ \\
\hline BMI $\left(\mathrm{kg} / \mathrm{m}^{2}\right)$ & $33.1(24.8-50.7)$ & $31.5(23.7-50.4)$ \\
\hline BMl z-score & $3.4(0.9-9.5)$ & $2.9(0.7-9.4)$ \\
\hline
\end{tabular}

${ }^{\text {a }}$ Data are expressed as mean value (range), BMI, body mass index, BW, body weight.

\section{Energy food intake}

To determine the intake of energy food diary records were kept for $72 \mathrm{~h}$ ( 2 weekdays and 1 weekend day) both before the start of the study (baseline intakes) and after the intervention (week 10). Detailed information on how to record food and drink consumed using common household measures was 
provided. Food diary records were returned to their dietician, and analyzed for energy contents based on the CESNID food-composition database of Spanish foods. ${ }^{16}$

\section{Biochemical analyses}

Fasting plasma glucose, total cholesterol, triglycerides, and HDL cholesterol were measured by enzyme-colorimetric automated methods (Roche, Neuilly sur Seine Cedex, France). LDL cholesterol was calculated by the Friedwald equation. Fasting plasma insulin was measured by the LINCOplex KIT Human Gut Hormone Panel (CAT-HGT-68K, Linco Research-St Charles, MO - USA).

\section{Fecal sample collection and preparation for microbiological analyses}

Fecal samples were collected at baseline and after 10 weeks of the intervention, frozen immediately after collection at $-20{ }^{\circ} \mathrm{C}$, and stored until analysed. Feces were diluted 1:10 $\left(\mathrm{w} / \mathrm{v}^{-1}\right)$ in PBS (pH 7.2) and homogenized in a Lab Blender 400 stomacher (Seward Medical London, UK) for 5 min. After low-speed centrifugation (2000 g, $2 \mathrm{~min})$, the supernatant was collected. For bacterial quantification, cells were fixed by adding $4 \%$ paraformaldehyde solution (Sigma, St Louis, MO, USA) and incubated overnight at $4{ }^{\circ} \mathrm{C}$. After fixation, bacteria were washed two times in PBS by centrifugation (12000 g for $5 \mathrm{~min})$. Finally, cell pellets were suspended in a PBS/ethanol mixture (1:1) and stored at $-80{ }^{\circ} \mathrm{C}$ until analyzed as described earlier. ${ }^{17}$ 


\section{Fluorescent in situ hybridisation for microbiological analysis}

The bacterial groups present in feces were quantified by fluorescent in situ hybridization (FISH) using group-specific probes (MOLBIOL, Berlin, Germany). The specific probes and controls used in this study, as well as the hybridization conditions, are shown in Table 2. The EUB 338 probe, targeting a conserved region within the bacterial domain, was used as a positive control, ${ }^{16}$ and the NON 338 probe was used as a negative control to eliminate background fluorescence. ${ }^{17}$ Control probes were covalently linked at their 5 'end either to indocyanine dye $\mathrm{Cy} 3$ or to fluorescein isothiocyanate (FITC). Specific cell enumeration was performed by combining each of the groupspecific FITC-probes with the EUB 338-Cy3 probe as previously described. ${ }^{17}$ Briefly, fixed cell suspensions were incubated in the hybridization solution (10 $\mathrm{mM}$ Tris-HCl, $0.9 \mathrm{M} \mathrm{NaCl}, \mathrm{pH} 8.0$ and $10 \% \mathrm{SDS}$ ) containing $4 \mathrm{ng} / \mu \mathrm{l}^{-1}$ of each fluorescent probe at appropriate temperatures, overnight. Then, hybridized cells were pelleted by centrifugation (10 $000 \mathrm{~g}$ for $5 \mathrm{~min}$ ) and resuspended in $500 \mu \mathrm{l}$ PBS solution for flow-cytometry analysis. The proportion of each bacterial group was expressed as a ratio of cells hybridizing with the FITClabelled specific probe to cells hybridizing with the EUB 338-Cy3 probe. ${ }^{17}$

Table 2. Oligonucleotide probes and hybridization conditions used in the analysis of intestinal bacterial by fluorescent in situ hybridization 


\section{Capítulo I}

\begin{tabular}{|c|c|c|c|c|}
\hline Probe & Target bacterial group & Sequence $\left(5^{\prime}-3^{\prime}\right)$ & Hybridization conditions $(\mathrm{C})$ & References \\
\hline EUB338 & Domain bacteria & GCTCCCTCCCGTAGGAGT & 50 & 18 \\
\hline NON338 & Negative control & ACATCCTACCGGAGCC & 50 & 19 \\
\hline Bif1 64 & Bifidobacterium & CATCCGGCATTACCACCC & 50 & 20 \\
\hline Chis1 50 & Clostridium histolyticum & TTATGCGGTATTAATCT(C/T) CCTTT & 50 & 21 \\
\hline Clit135 & Clostridium lituseburense & GTTATCCGTGTGTACAGGG & 50 & 21 \\
\hline Erec0482 & Eubacterium rectale/Clostridium coccoides & GCTTCTTAGTCACGTACCG & 50 & 21 \\
\hline Lab158 & Lactobacillus/Enterocaccus & GGTATTAGCA(C/T)CTGTTTCCA & 45 & 22 \\
\hline Bac303 & Bacteraides/Prevotella & CCAATCTCGCGCACCTT & 45 & 23 \\
\hline Enter1 432 & Enterobacteriaceae & СТTTСССАСCCACT & 50 & 24 \\
\hline Ecol 1513 & Escherichia coll & CACCGTAGTCCCTCGTCATCA & 50 & 25 \\
\hline Rrec584 & Roseburia subcluster & GGCACCTTCTTCTCAGT & 50 & 26 \\
\hline SRB687 & Sulphate-reducing bacteria & TACGGATTTCACTCCT & 50 & 27 \\
\hline
\end{tabular}

\section{Immunoglobulin-coating bacterial analysis}

Bacterial cells from $20 \mu 1$ of the supernatant obtained after low-speed centrifugation were collected (10 $000 \mathrm{~g}$ for $5 \mathrm{~min}$ ). The pellet was resuspended in $60 \mu 11 \%\left(\mathrm{w} / \mathrm{v}^{-1}\right)$ BSA/PBS, containing $1 \%\left(\mathrm{v} / \mathrm{v}^{-1}\right)$ FITC-labelled $\mathrm{F}\left(\mathrm{ab}{ }^{\prime}\right) 2$ antihuman IgA, IgG or IgM (CALTAG Laboratories, Burlingame, CA, USA). Another aliquot of each sample was pelleted and resuspended in $60 \mu 11 \%$ $\left(\mathrm{w} / \mathrm{v}^{-1}\right) \mathrm{BSA} / \mathrm{PBS}$ and used as control. After $30 \mathrm{~min}$ incubation, suspensions were washed two times with PBS. Bacterial pellet was finally resuspended in $500 \mu \mathrm{l}$ PBS and mixed with $20 \mu \mathrm{l}$ propidium iodine $\left(100 \mathrm{mg} \mathrm{l}^{-1}\right)$ to label total bacteria before flow-cytometry detection. ${ }^{28}$

\section{Flow cytometry}

Flow-cytometry detections were performed using an EPICS XL-MCL flow cytometer (Beckman Coulter, Florida, USA) as described earlier. ${ }^{17}$ This instrument is equipped with two light scatter detectors that measure forward (FSC) and side scatter (SSC) and fluorescence detectors that detect 
appropriately filtered light at green (FL1, $525 \mathrm{~nm}$ ) and red-orange (FL3, 620 $\mathrm{nm})$ wavelengths. The event rate was kept at the lowest setting (200-300 events per second) to avoid cell coincidence. A total of 15000 events were recorded in a list mode file and analyzed with the System II V.3 software (Beckman Coulter). The proportion of each bacterial group was expressed as a ratio of cells hybridizing with the FITC-labelled specific probe to cells hybridizing with the universal EUB 338-Cy3 probe. ${ }^{17}$ Immunoglobulin coating of faecal bacteria was expressed as a ratio of bacterial cells labelled with FITC-labelled $\mathrm{F}\left(\mathrm{ab}^{\prime}\right) 2$ antihuman IgA, IgG or IgM to the total cell population hybridizing with propidium iodine.$^{28}$

\section{Fecal energy determination}

Energy content of feces was determined by calorimetry as described elsewhere $^{29}$ using an Automatic Adiabatic Bomb Calorimeter (Gallenkamp, Leicestershire, UK). Fecal samples were dried by lyophilization and samples of $1.5 \mathrm{~g}$ dry weight were analysed in duplicated. Gross energy content of faecal samples was defined as the amount of heat developed by the total combustion of a unit of dry weight sample.

\section{Statistical analyses}

Statistical analyses were done using the SPSS 11.0 software (SPSS Inc, Chicago, IL, USA). Results are expressed as median values and ranges determined in duplicate. Total bacteria, Gram-positive and Gram-negative bacteria were calculated by adding the proportions of the corresponding groups 
detected by specific probes, which do not overlap. Thus, total Gram-positive bacteria was calculated by adding the proportions obtained with the probes Chis150, Erec0482, Bif164, Clit135 and Lab158 and total Gram-negative was calculated by adding the proportions obtained with the probes Bac303, Ent1432 and SBR687. Differences in bacterial populations immunoglobulincoating bacteria, fecal energy and biochemical parameters detected before and after the intervention programme were determined using the Mann-Whitney $U$-test of non-normal data distribution. The Spearman's correlation test was used to calculate the correlations between bacterial count changes and either weight loss or biochemical changes as a result of the intervention. In every case, a $P$-value $<0.05$ was considered statistically significant.

\section{Statement of ethics}

We certify that all applicable institutional and governmental regulations concerning the ethical use of human volunteers were followed during this research. Informed consent was obtained from all adolescents and their parents, and the study was approved by the local Ethics Committees. 


\section{RESULTS}

\section{Participants}

Clinical characteristics did not differ significantly between the two groups of adolescents (A and B) at recruitment time (Table 1). Base line values of BMI and BMI $z$-score of group A were 30.7 (26.4-36.3) and 2.95 (1.6-4.03), respectively and those of group B were 33.1 (30.0-35.0) and $3.22(2.57-4.16)$, respectively. The subjects, 51\% female (20/39) and 49\% male (19/39), were 14.4 years old (13.0-16.0 years), maintained an apparently good health status and did not consume antibiotics during the study (Table 1).

Most of the participants $(\mathrm{n}=26)$ experienced significant $(P=0.050)$ weight loss from 4.1 to $16.6 \mathrm{~kg}$ (mean decrease of $7.6 \mathrm{~kg}$ ) after 10 weeks of following the intervention programme. Some of them $(n=13)$ did not experience remarkable weight loss (mean decrease of $1.1 \mathrm{~kg}$; range $0.8-2.4$ $P=0.798)$. These two groups showed significant differences in their weight loss $(P<0.001)$ and BMI $z$-score reduction $(P<0.001)$ and, accordingly, were subdivided for comparisons of their fecal bacterial populations into groups A ( $>4 \mathrm{~kg}$, mean $7.6 \mathrm{~kg}$ weight loss) and $\mathrm{B}(<2.5 \mathrm{~kg}$, mean $1.1 \mathrm{~kg}$ weight loss). BMI, and, BMI $z$-score ( $P=0.033$ and $P=0.039$, respectively) detected before and after the dietary intervention was also significantly different in group A but not in group B. Group A was further subdivided into other two groups that also displayed significant differences in weight loss $(P<0.001)$, one (group A1) integrated by participants with a weight loss of 4-6 $\mathrm{kg}$ (corresponding to a 5.5 $\%$ decrease in body weight) and the other (group A2) integrated by those 
participants with a weight loss exceeding $6 \mathrm{~kg}$ (corresponding to $9.4 \%$ decrease in body weight) for comparisons of fecal immunoglobulin coating bacteria as indicated below.

The dietary intervention resulted in a significant reduction $(P<0.050)$ in total energy intake in both adolescent groups from 2284 (2739-1549) to 1429.4 (1049-1782) kcal/day ${ }^{-1}$ in group A and from 2159 (1926-2414) to 1416 (1296-1508) kcal/day ${ }^{-1}$ in group B. No significant differences in dietary energy intake were found between both adolescent groups before and after the intervention program.

\section{Microbiota composition and energy of feces from adolescents}

A follow-up study was made of the shifts in composition of fecal microbiota of the participants under study during the weight loss intervention programme. The results of the fecal microbiota analyses before and after intervention by FCM-FISH techniques are shown in Figures 1 and 2, and Table 3.

In the whole adolescent population, the intervention programme led to reductions in Clostridium histolyticum proportions, which correlated with weight loss (Figure 1a; $r=0.43 ; P=0.009$ ), as did reductions in E. rectale-C. coccoides proportions (Fig $1 \mathrm{~b} ; r=0.50, P=0.001$ ). Similar correlations were found between $C$. histolyticum and E. rectale-C. coccoides proportions and BMI $z$-scores $(r=0.41 ; P=0.012$ and $r=0.39 ; P=0.014$, respectively). 
a

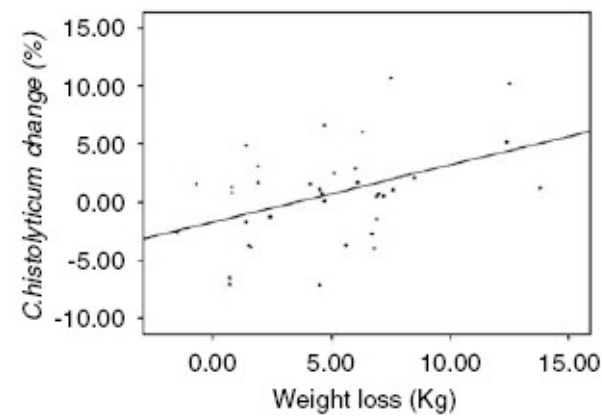

c

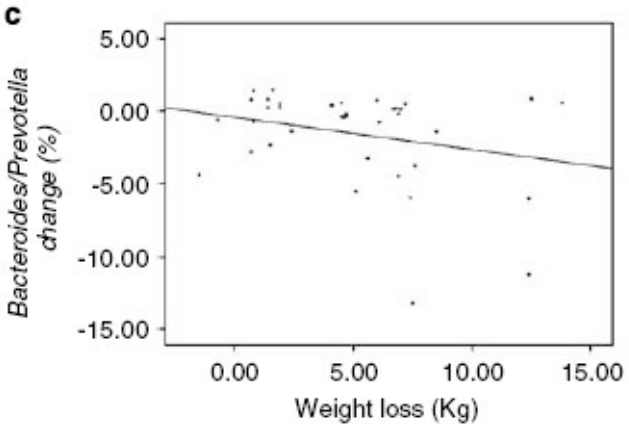

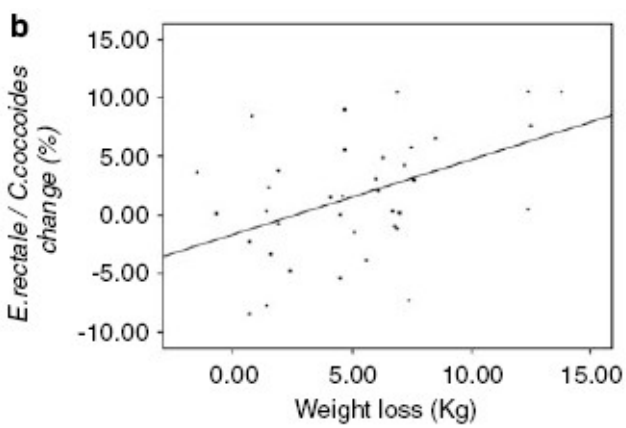

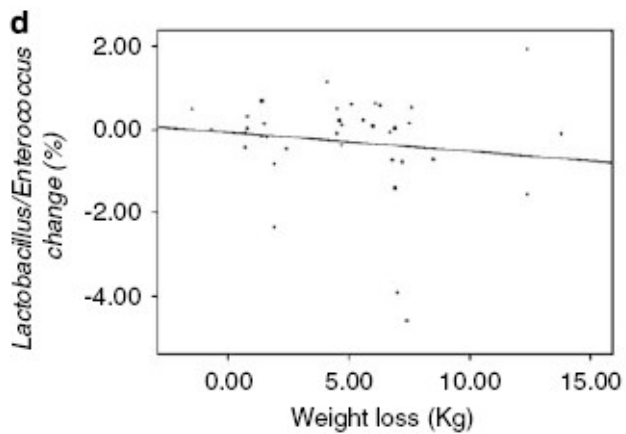

Figure 1. Correlation between changes in different bacterial groups (\% before - $\%$ after intervention) and weight loss ( $\mathrm{kg}$ before - $\mathrm{kg}$ after diet). Spearman's correlations: $C$. histolyticum changes and weight loss; $r=0.43, P=0.009$ (a) E.rectale-C. coccoides changes and weight loss; $r=0.50, P=0.001$ (b) Bacteroides-Prevotella changes; $r=-0.28, P=0.083$ (c) Lactobacillus-Enterococcus changes and weight loss; $r=-0.15, P=0.365$ (d).

Bacteroides proportions increased as a result of the intervention and almost reached significant levels of correlation with weight loss (Figure 1c; $r=-$ $0.28 ; \quad P=0.083)$. Although increases in Lactobacillus-Enterococcus proportions were also parallel to reductions in weight (Figure 1d; $r=-0.15 ; P$ $=0.361)$ and BMI z-scores $(r=-0.29 ; P=0.074)$, correlation was not significant. Shifts in Bifidobacterium, C. lituseburense, Enterobacteriaceae, Escherichia coli, Roseburia and sulphate-reducing bacterial groups were neither significantly correlated with weight loss nor with BMI z-score reductions. 


\section{Capitulo I}
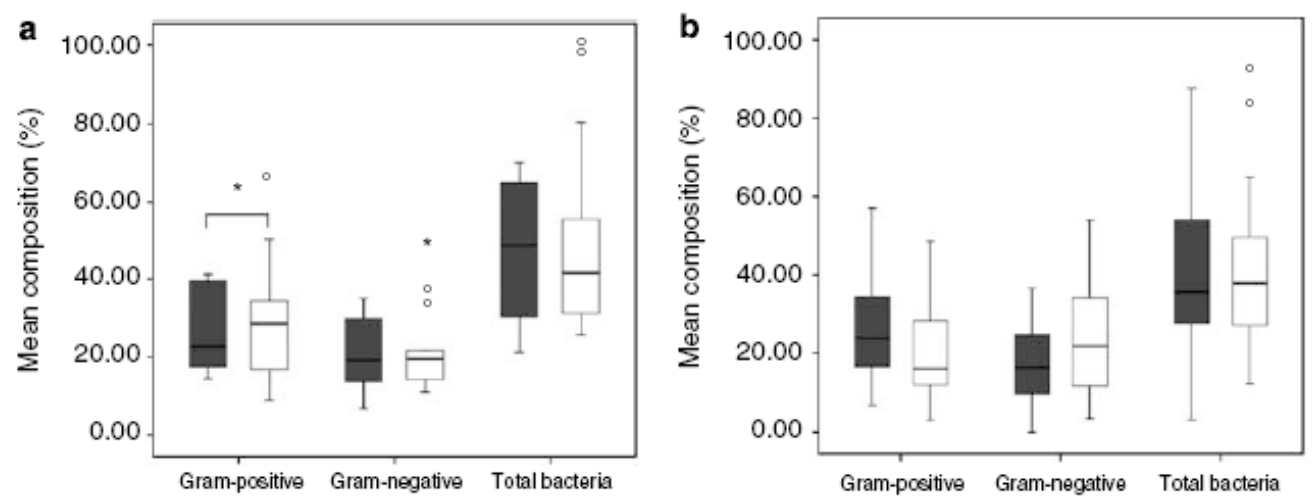

Figure 2. Overall bacterial composition in two adolescents groups: group A with $>4 \mathrm{~kg}$ weight loss (A); group B with $<2.5 \mathrm{~kg}$ weight loss (B). total Gram-positive bacteria was calculated by adding the proportions obtained with the probes Chis150, Erec0482, Bif164, Clit135 and Lab158 and total Gram-negative was calculated by adding the proportions obtained with the probes Bac303, Ent1432 and SBR687. *Significant differences $(P<0.05)$ between median values before (grey) and after (white) intervention programme by using the Mann-Whitney $U$ test.

The composition of the fecal microbiota of two groups of adolescents A and $\mathrm{B}$, which displayed significant differences in weight loss $(>4 \mathrm{~kg}$ in group A versus $<2.5 \mathrm{~kg}$ in group B) and BMI z-score reduction after intervention, was compared at base line, revealing the presence of significantly higher levels $(P=0.008)$ of Lactobacillus proportions in the group A than in group B (Table 3). In group A, Gram-positive bacterial populations, estimated by adding the proportions of corresponding groups targeted by the probes, were significantly lower $(P=0.046)$ after the intervention, whereas significant differences in Gram-negative bacteria and total bacteria were not detected (Figure 2a). In contrast, in group B no differences were detected in Gram-positive, Gramnegative or total bacteria proportions present in feces before and after the intervention (Figure 2b). 
Table 3. Bacterial composition ${ }^{a}$ of faecal samples as assessed by fluorescence in situ hybridization

\begin{tabular}{|c|c|c|c|c|c|c|}
\hline \multirow[t]{2}{*}{ Bacterial group } & \multicolumn{2}{|c|}{$\begin{array}{c}\text { Group A } \\
\text { Adolescents with }>4.0 \mathrm{~kg} \text { weight loss }(\mathrm{n}=26)\end{array}$} & \multirow[b]{2}{*}{ P.value } & \multicolumn{2}{|c|}{$\begin{array}{c}\text { Group B } \\
\text { Adolescents with }<2.5 \mathrm{~kg} \text { weight loss }(\mathrm{n}=13)\end{array}$} & \multirow[b]{2}{*}{ P-value } \\
\hline & Before intervention & After intervention & & Before intervention & After intervention & \\
\hline Bifidobacterium & $8.31(20.48-0.51)$ & $7.85(19.58-1.2)$ & 0.898 & $8.72(25.48-1.49)$ & $7.14(15.67-4.23)$ & 0.497 \\
\hline C. histolytiaum & $5.38(13.04-2.02)$ & $2.95(13.12-0.47)$ & $0.011^{\star}$ & $6.04(13.34-1.44)$ & $7.31(12.52-4.14)$ & 0.573 \\
\hline c. lituseburense & $2.53(17.3-0.33)$ & $1.45(17-0.16)$ & $0.049^{\star}$ & $2.73(28.04-0.42)$ & $1.98(18.61-0.52)$ & 0.538 \\
\hline E.rectale/C.coccoides & $7.51(19.4-1.53)$ & $4.55(20.57-0.51)$ & $0.033^{*}$ & $5.98(14.23-1.37)$ & $8.02(21.33-0.76)$ & 0.978 \\
\hline Lactobacillus/Enteroccoccus & $1.01(3.15-0.16)$ & $1.31(5.64-0.08)$ & 0.604 & $0.57(2.88-0.24)$ & $0.65(2.79-0.1)$ & 0.663 \\
\hline Bacteroides/Prevotella & $2.51(6.92-1.13)$ & $3.09(16.14-0.93)$ & $0.047^{\star}$ & $1.83(4.30-0.22)$ & $1.77(7.10-0.34)$ & 0.681 \\
\hline Enteric group & $7.27(22.17-0.43)$ & $7.96(23.21-0.74)$ & 0.833 & $6.44(14.58-2.60)$ & $6.78(17.59-1.64)$ & 0.682 \\
\hline E. coli & $4.48(17.96-0.11)$ & $5.12(26-0.1)$ & 0.503 & $2.30(11.57-0.20)$ & $1.97(7.76-0.56)$ & 0.457 \\
\hline Roseburia & $6.01(15.75-2.8)$ & $8.36(19.49-2.02)$ & 0.304 & $4.78(11.55-1.56)$ & $5.34(12.67-2.97)$ & 0.383 \\
\hline Sulphate-reducing bacteria & $7.41(20.61-0.15)$ & $6.76(22.45-0.3)$ & 0.749 & $4.79(17.07-0.87)$ & $5.62(15.12-1.46)$ & 0.758 \\
\hline
\end{tabular}

${ }^{a}$ Data were expressed as median proportions of bacterial cell hybridizing with specific-group probes to total bacteria hybridizing with EUB probe 338 and ranges. ${ }^{*}$ Significant differences $(\mathrm{P}<0.050)$ between median values of different bacterial group proportions before and after diet were established by using Mann-Whitney $U$-test

In group A, which experienced important weight loss ( $>4 \mathrm{~kg})$ and BMI $z$-score reductions (mean decrease 1.05; range 1.86-0.38), C. histolyticum, $C$. lituseburense and $E$. rectale-C. coccoides proportions decreased significantly after the intervention programme $(P=0.011, P=0.049$, and $P=0.033$, respectively), whereas those of Bacteroides-Prevotella group were significantly increased $(P=0.047)$ Lactobacillus-Enterococcus, Enterobacteriaceae, E. coli, and Roseburia groups showed slight increases whereas Bifidobacterium and sulphate-reducing bacteria tended to decrease but these changes were not statistically significant. Reduced C. Histolyticum and E. rectale-C. coccoides proportions significantly correlated with percentage of body weight loss ( $r=0.48 ; P=0.020$ and $r=0.41 ; P=0.036$, respectively) and those of E. rectale-C. coccoides with BMI z-score reductions $(r=0.36$; 
$P=0.020$ and $r=0.41 ; P=0.036$, respectively). In the adolescents group $\mathrm{B}$, who did not experience a significant weight loss, none of the analyzed bacterial groups showed statistically significant differences before and after the intervention programme (Table 3). No correlations were detected between bacterial proportions and either body weight or BMI $z$-score reductions.

Fecal energy content before $\left(5.43(5.11-5.90) \mathrm{kcal} \mathrm{g}^{-1}\right)$ and after (5.16 (4.94-5.28) $\mathrm{kcal}^{-1}$ ) the intervention was almost significantly reduced $(P=0.055)$ in group A of adolescents. In contrast, fecal energy content before (5.42 (5.04-5.66) $\left.\mathrm{kcal} \mathrm{g}^{-1}\right)$ and after (5.33 (5.2-5.42) $\left.\mathrm{kcal} \mathrm{g}^{-1}\right)$ the intervention was not significantly different $(P=0.513)$ in group B of adolescents.

\section{Biochemical parameters and correlations with faecal microbiota}

Biochemical parameters in both groups of adolescents before and after the intervention are shown in Table 4 . No significant differences were found in the analyzed biochemical parameters between both adolescent groups A and B before the intervention (base line) except for LDL levels, which were higher in group $\mathrm{B}$ of adolescents $(\mathrm{P}=0.034)$.

Serum HDL-cholesterol values were significantly higher $(P=0.031)$ before than after the intervention in group B of adolescents but did not correlate with any bacterial group changes. Slight changes in serum glucose concentration correlated with slight changes in E. rectale-C. coccoides as a result of the intervention in group B of adolescents $(r=0.683, P=0.030)$. Serum 
glucose $(P=0.029)$ and total cholesterol $(P=0.012)$ concentration significantly dropped in group A of adolescent after the intervention.

Table 4. Biochemical parameters determined in plasma of adolescents before and after the intervention

\begin{tabular}{|c|c|c|c|c|c|c|c|c|c|c|}
\hline \multirow[t]{3}{*}{ Parameters } & \multicolumn{4}{|c|}{$\begin{array}{c}\text { Group B } \\
\text { Adolescents with }<2.5 \mathrm{~kg} \text { weight loss }(\mathrm{n}=13)\end{array}$} & \multirow[b]{3}{*}{ P-value } & \multicolumn{4}{|c|}{$\begin{array}{c}\text { Group A } \\
\text { Adolescents with }>4.0 \mathrm{~kg} \text { weight loss }(n=26)\end{array}$} & \multirow[b]{3}{*}{ P-value } \\
\hline & \multicolumn{2}{|c|}{ Before intervention } & \multicolumn{2}{|c|}{ After intervention } & & \multicolumn{2}{|c|}{ Before intervention } & \multicolumn{2}{|c|}{ After intervention } & \\
\hline & Median & Range & Median & Range & & Median & Range & Median & Range & \\
\hline Glucose (mg per $100 \mathrm{ml})$ & 85.5 & $83.5-90.0$ & 83.0 & $78.0-87.0$ & 0.309 & 87.5 & $83.0-99.7$ & 83.0 & $76.7-90.2$ & $0.029^{\star}$ \\
\hline Total cholesterol (mg per $100 \mathrm{ml}$ ) & 141.0 & $121.0-158.0$ & 141.0 & $129.0-152.0$ & 0.977 & 152.5 & $133.0-163.0$ & 132.5 & $123.7-147.0$ & $0.012^{\star}$ \\
\hline Triglycerides (mg per $100 \mathrm{ml}$ ) & 70.0 & $54.5-88.0$ & 71.0 & $59.0-100.0$ & 0.562 & 84.0 & $57.5-121.5$ & 73.5 & $50.0-106.5$ & 0.527 \\
\hline HDL cholesterol (mg per $100 \mathrm{ml}$ ) & 48.0 & $40.0-82.0$ & 45.0 & $36.0-49.0$ & 0.236 & 46.0 & $40.5-50.0$ & 45.0 & $39.0-63.0$ & 0.836 \\
\hline LDL cholesterol (mg per $100 \mathrm{ml}$ ) & 73.0 & $70.5-101.0$ & 49.0 & $40.5-75.5$ & $0.031^{\star}$ & 79.0 & $52.2-98.7$ & 75.5 & $65.0-86.2$ & 0.391 \\
\hline Insulin $\left(\mathrm{pg} \mathrm{ml}^{-1}\right)$ & 344.2 & $529.0-664.0$ & 504.6 & $349.0-760.0$ & 0.555 & 471.6 & $417.1-772.0$ & 421.5 & $263.0-632.0$ & 0.139 \\
\hline
\end{tabular}

*Statistical differences before and after the intervention were calculated using the MannWhitney U-test and established at $\mathrm{P}<0.050$

. Changes in glucose and cholesterol significantly correlated with changes in the enteric group proportions $(r=-0.547, P=0.006$ and $r=-0.462, P=0.035$, respectively). In addition, changes in glucose significantly correlated with changes in total Gram-negative bacteria $(r=-0.538, P=0.012)$. LDL-cholesterol was reduced after the intervention although not significantly and correlated to changes in $C$. lituseburense proportions $(r=-0.508, P=0.019)$.

\section{Immunoglobulin-coating bacteria in faeces from adolescents}

Immunoglobulin-coating bacteria were detected in feces of adolescents who experienced the greatest loss ( $>4 \mathrm{~kg}$; group A) in body weight (Figure 3). Overall, higher percentages of $\operatorname{IgA}, \operatorname{IgM}$ and $\operatorname{IgG}$-coating bacteria were detected in feces of adolescents before the intervention than after it. The proportions of IgA-coating bacteria were significantly reduced $(P=0.034)$ after 


\section{Capitulo I}

the intervention programme in group A1 of participants, who lost over $6 \mathrm{~kg}$, whereas these differences were not significant in group A2 of participants with weight reductions between 4 and $6 \mathrm{~kg}$ (Figure 3).

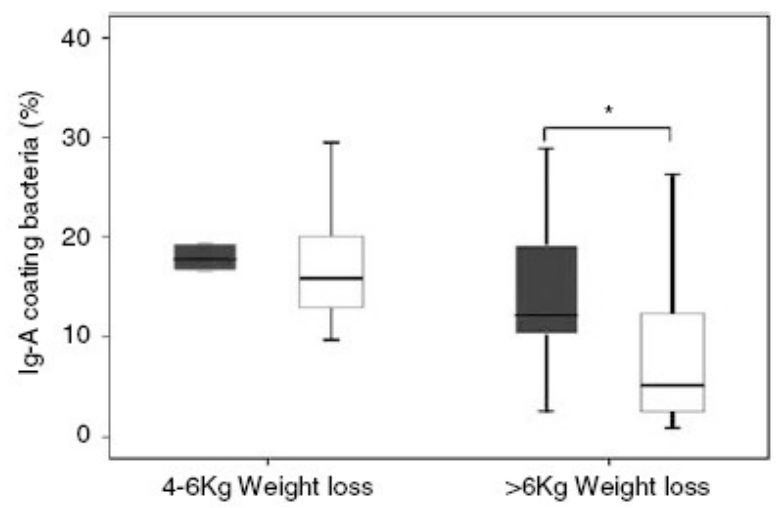

Figure 3. Mean percentage of fecal bacteria coated with $\operatorname{IgA}$. ${ }^{*}$ Significant differences $(P<$ 0.05 ) between median values of different groups (A1 group of adolescents with weight loss 4-6 $\mathrm{kg}$ and $\mathrm{A} 2$ group of adolescents with weight loss $>6 \mathrm{~kg}$ ) before (black) and after (white) intervention programme by using the Mann-Whitney $U$-test.

Group A1 also revealed significant reductions in proportions of $C$. histolyticum, and $E$. rectale-C. coccoides groups $(P=0.046$ and $P=0.044$, respectively) whereas changes in group A2 did not reach statistical significance $(P<0.050)$, indicating that these bacteria exerted the greatest influence on IgA-coating bacterial changes. In addition, reduced $E$. rectale- $C$. coccoides proportions in group A1 significantly correlated with the percentage of body weight loss and BMI $z$-score reduction $(r=0.56 ; P=0.023$ and $r=0.53$; $P=0.035$, respectively). Group A1 also showed significantly lower proportions of total Gram-positive bacterial populations $(P=0.034)$ after the intervention programme, whereas no significant differences in Gram-negative bacteria and 
total bacteria were detected. Therefore, changes in IgA secretion against the gut microbiota could be explained by specific changes in its composition associated with weight loss.

\section{Discussion}

Diet is considered to be one of the main environmental factors shaping the composition of the gut microbiota within a host and affecting their functional relationships. This study has demonstrated that a weight-loss intervention programme, based on a calorie restricted diet and increased physical activity, induced changes in the gut microbiota structure of obese adolescents and that some of these changes correlated with weight loss and BMI z-score reductions. Therefore, the relative abundance of specific gut bacteria seems to be susceptible to lifestyle intervention and may be an additional element for consideration in weight management strategies.

Reduced E. rectale-C. coccoides and C. histolyticum proportions were significantly correlated with weight loss and BMI z-score reduction in the total population. By contrast, Bacteroides proportions increased as a result of the intervention programme, although their correlations with weight loss and BMI z-scores did not reach statistical significance. In previous human studies in adults, decreases in Firmicutes division, which include Clostridium clusters, as well as increases in Bacteroidetes division have also been correlated with the percentage of body weight loss; however, a very limited number of participants were included in the corresponding study. ${ }^{10}$ Therefore, the present report has confirmed that the abundance of these two bacterial groups in the distal gut 


\section{Capitulo I}

could be linked to human weight loss although controversial results have also been reported recently. ${ }^{13}$

Specific fecal bacterial proportions differed significantly in group A of adolescents, who experienced a remarkable weight loss ( $>4 \mathrm{~kg})$ representing on average $8.1 \%$ of their body weight, as a result of the intervention. Accordingly, previous studies have indicated that Firmicutes and Bacteroides changes are associated with weight-loss percentage. These changes were only evident when the individuals had lost at least between 2 and $6 \%$ of their body weight, without finding a relationship to the type of diet (either fat or carbohydrate restricted). ${ }^{10}$ Overall, total Gram-positive bacterial populations were significantly reduced and Gram-negative bacteria slightly increased after the intervention programme in group A of adolescents. C. histolyticum, E. rectale-C. coccoides and $C$. lituseburense were identified as the main contributors to the overall reduction in Gram-positive bacteria, whereas Bacteroides group contributed to the increase in total Gram-negative bacteria.

These gut microbes could play a role in obesity together with diet by affecting either host metabolism, ${ }^{6}$ or the signalling pathways that link inflammation with obesity. ${ }^{12}$ E. rectale-C. coccoides group includes clostridia cluster XIV, which integrates the main butyrate-producing bacteria in the distal colon. ${ }^{29}$ These bacteria are responsible for generating butyric acid from carbohydrate fermentation, which fuels epithelial cells covering up to $70 \%$ of their energy needs. ${ }^{30}$ The reduction of these bacterial groups by intervention in obese adolescents could contribute to reducing the overall ability of the gut 
microbiota to harvest energy from the diet, which could account for up to 10$15 \%$ of our daily caloric supply. ${ }^{31}$ Nevertheless, butyrate generation by gut microbes has generally been associated with beneficial effects, including satiety promotion, rather than with obesogenic features, ${ }^{32}$ indicating that more complex mechanisms related to fatty-acid metabolism could link Firmicutes and Clostridium clusters with obesity.

C. histolyticum proportions were also reduced after the intervention programme in adolescents and these shifts were correlated with weight loss. This group belongs to clostridia cluster II, which are highly proteolytic and produce acetate as the main end product of metabolism. ${ }^{33}$ Increased levels in colonic and serum acetate, which may stimulate lipid synthesis, have also been associated with microbial gut colonization. ${ }^{34,35}$ In addition, C. histolyticum produces proteases that are cytotoxic for cells and tissues and could be pathogenic factors in the gut environment. The prevalence of this clostridial group could also increase protein fermentation in the colon with the subsequent generation of toxic compounds such as sulphur-containing metabolites. ${ }^{11} C$. lituseburense group, which is included in clostridia cluster XI, was also decreased after the intervention in group $\mathrm{A}$ of adolescents. This is a heterogeneous phylogenetic cluster but comprises opportunistic pathogens, such as $C$. difficile, and its abundance together with that of $C$. histolyticum group could modify the potential virulence of the gut microbiota in obese patients, which in turn was improved in adolescents showing the highest weight loss. ${ }^{33}$ In contrast to Clostridium groups, Bacteroides were increased in individuals showing a significant weight loss $(<4 \mathrm{~kg})$ after the dietary 


\section{Capitulo I}

intervention, which may be related to changes in the type of short-chain fatty acid generated and colonic $\mathrm{pH}$ increases. ${ }^{36}$ Increased Bacteroides populations could contribute to generating propionate, which has been shown to inhibit lipid synthesis from acetate and may favour a lean phenotype..$^{35,37}$

The study has also showed almost significant changes in total fecal energy in group A of adolescents after the intervention whereas not in group B. Although the fecal energy only reflect part of the energy supply that could be due to the colonic microbiota, the obtained results could partly explain the detected differences in weight loss between the two adolescent groups (A and B) paralleled to microbiota changes. In fact, differences in total fecal energy between both adolescent groups could not be related to differences in total dietary energy intake. Therefore, these and previous results point for a role of gut bacteria other than common probiotic genera in weight management and, therefore, the current dietary strategies used to modulate the gut microbiota based on the administration of lactobacilli, bifidobacteria and prebiotics that favour their predominance could be questioned in obesity control.

Nevertheless, a recent study has not found correlations between Bacteroides populations and obesity by comparing obese and non-obese partiucipants and there was not significant relationship between changes in the percentage of Bacteroides in feces and weight loss under reduced calorie diets. ${ }^{13}$ Significant shifts detected in Roseburia-E. rectale groups detected with the probe Rrec482 and Bifidobacterium were related to reductions in carbohydrate intake but regardless weight loss. ${ }^{13}$ By contrast, the present study 
has not shown significant reductions in these bacterial groups in feces of participants submitted to energy intake reduction, including carbohydrate restrictions (approximately 28\% reduction), but confirmed previous relations between Clostridium and Bacteroides groups with weight loss under dietary intervention. ${ }^{10}$ Therefore, the possibility that weight loss depends on both the diet and its interactions with gut microbiota could not be completely disregarded.

Glucose and LDL-cholesterol reductions detected in group A of adolescents were also correlated with shifts in total Gram-negative bacteria and C. lituseburense. Although further studies should be carried out to confirm these trends, the results also suggest interactions between diet, gut bacteria and host's metabolism as proposed earlier. ${ }^{10}$

Obesity and related disorders, such as the metabolic syndrome, are also associated with a chronic low-grade inflammation even at early ages, exemplifying the link between metabolism and immunity. ${ }^{4}$ In this study, gut microbiota has been identified as a factor stimulating host immunity to different extents depending on weight loss. Elevation of IgA coating bacteria before the intervention programme could be an indication of low-grade inflammation triggered by the gut microbiota before intervention, as this microbiota is characterized by increased levels of opportunistic pathogens when compared with that detected after the diet in group A1 of adolescents. ${ }^{38}$ 


\section{Capitulo I}

The decrease in IgA-coating bacteria detected after the intervention was particularly associated with reductions in $C$. histolyticum and E. rectale- $C$. coccoides proportions. The reductions in butyrate-producing bacteria of $E$. rectale-C. coccoides group, as a result of the intervention programme, could also be responsible for reducing energy availability for immune cells leading to reducing IgA-producing cells and mucosal IgA concentrations..$^{39,40}$ Our results suggest that the increased host immune response trigger by the gut microbiota can be modified in overweight adolescents by a lifestyle intervention, confirming that there is a relationship between gut microbiota and host immunity in obese human subject.

The limitations of the study include the relative small sample size of subgroups due to differences in weight loss responses of the whole population group and the short duration of the intervention, which could reduce the significance of the detected changes. However, this short-term study confirmed and complemented the results of a previous long-term study (1 year) by using different molecular techniques that target specific bacterial groups.

All in all, this study has provided stronger links between specific bacterial groups and body weight in adolescents under a lifestyle intervention. This study also suggest a role for the gut microbiota in this disorder related to both host metabolism and immunity, evidenced by shifts in the bacteria driving the main metabolic pathways in the colon and showing different pathogenic features, although direct evidence should still be provided. 


\section{Acknowledgments}

Declaration of personal and funding interests: This work was supported by Grants AGL2005-05788-C02-01 from the Spanish Ministry of Education of Science and Innovation and AP 002/07 from Consejería de Sanidad (Valencia, Spain). The EVASYON study was supported by grants from Spanish Ministry of Health (PI051574). The scholarship to I. Nadal from Generalidad Valenciana (Spain) and CSIC 200570F0091 (Spain) is fully acknowledged. The scholarship from CONACYT (México) to A Santacruz is fully acknowledged.

\section{References}

1 Cole TJ, Belizzy MC, Flegal KM, Dietz WH. Establishing a standard definition for child overweight and obesity worldwide: international survey. $\mathrm{Br} \mathrm{Med} \mathrm{J}$ 2000; 320: 1-6.

2 Moreno LA, Mesana MI, González-Gross M, Gil CM, Fleta J, Wärnberg J et al. Bueno $M$ and the AVENA Study Group. Anthropometric body fat composition reference values in Spanish adolescents. The AVENA Study. Eur J Clin Nutr 2006; 60: 191-196.

3 Badman MK, Flier JS. The adipocyte as an active participant in energy balance and metabolism. Gastroenterology 2007; 132: 2103-2115.

4 Wärnberg J, Nova E, Romeo J, Moreno LA, Sjöström M, Marcos A. Lifestylerelated determinants of inflammation in adolescence. Br J Nutr 2007; 98: 116120. 
5 Moreno LA, Ochoa MC, Wärnberg J, Marti A, Martínez JA, Marcos A. Treatment of obesity in children and adolescents. How nutrition can work? Int J Pediatr Obes 2008; 3: 72

6 Bäckhed F, Ding H, Wang T, Hooper LV, Koh GY, Nagy A, Semenkovich CF, Gordon JI. The gut microbiota as an environmental factor that regulates fat storage. Proc Natl Acad Sci U S A 2004 ; 101: 15718-15723.

7 Wabitsch M. Overweight and obesity in European children and adolescents: causes and consequences, treatment and prevention. An introduction.Eur $J$ Pediatr 2000; 159: 5-7.

8 Moreno LA, Rodríguez G. Dietary risk factors for development of childhood obesity. Curr Opin Clin Nutr Metab Care 2007; 10: 336-341.

9 Duncan SH, Belenguer A, Holtrop G, Johnstone AM, Flint HJ, Lobley GE. Reduced dietary intake of carbohydrates by obese subjects results in decreased concentrations of butyrate and butyrate-producing bacteria in feces. Appl Environ Microbiol 2007; 73: 1073-1078.

10 Ley RE, Turnbaugh PJ, Klein S, Gordon JI. Microbial ecology: human gut microbes associated with obesity. Nature 2006; 444: 1022-1023.

11 De Graaf AA, Venema K. Gaining insight into microbial physiology in the large intestine: a special role for stable isotopes. Adv Microb Physiol 2008; 53: 73-168.

12 Cani PD, Neyrinck AM, Fava F, Knauf C, Burcelin RG, Tuohy KM et al. Selective increases of bifidobacteria in gut microflora improve high-fat-dietinduced diabetes in mice through a mechanism associated with endotoxaemia. Diabetologia 2007; 50: 2374-2383.

13 Duncan SH, Lobley GE, Holtrop G, Ince J, Johnstone AM, Louis P, et al. Human colonic microbiota associated with diet, obesity and weight loss. Int $J$ Obes (Lond) 2008; 9: [Epub ahead of print]

14 Matsumoto M, Inoue R, Tsukahara T, Ushida K, Chiji H, Matsubara N et al. Voluntary running exercise alters microbiota composition and increases nbutyrate concentration in the rat cecum. Biosci Biotechnol Biochem 2008; 72: 572-576.

15 Rodriguez G, Moreno LA, Sarría A, Fleta J, Bueno M. Resting energy expenditure in children and adolescents: agreement between calorimetry and prediction equations. Clin Nutr 2002; 21: 255-260.

16 Farran A, Zamora R, Cervera P, CESNID. Tablas de composición de alimentos CESNID. $2^{\mathrm{a}}$ ed. Edicions Universitat de Barcelona - McGraw-Hill /Interamericana: Barcelona, 2004. 
17 Nadal I, Donat E, Riber-Koninckx C, Calabuig M, Sanz Y. Imbalance in the composition of the duodenal microbiota of children with coeliac disease. $J$ Med Microbiol 2007; 56: 1669-1674.

18 Amann RI, Binder BJ, Olson RJ, Chisholm SW, Devereux R, Stahl DA. Combination of $16 \mathrm{~S}$ rRNA-targeted oligonucleotide probes with flow cytometry for analyzing mixed microbial populations. Appl Environ Microbiol 1990; 56: 1919-1925.

19 Wallner G, Amann R, Beisker W. Optimizing fluorescent in situ hybridization with rRNA-targeted oligonucleotide probes for flow cytometric identification of microorganisms. Cytometry 1993; 14: 136-143

20 Langendijk PS, Schut F, Jansen GJ, Raangs GC, Kamphuis GR, Wilkinson $\mathrm{MH}$ et al. Quantitative fluorescence in situ hybridization of Bifidobacterium spp. With genus-specific 16S rRNA-targeted probes and its application in fecal samples. Appl Environ Microbiol 1995; 61: 3069-3075.

21 Franks AH, Harmsen HJ, Raangs GC, Jansen GJ, Schut F, Welling GW. Variations of bacterial populations in human feces measured by fluorescent in situ hybridization with group-specific 16S rRNA-targeted oligonucleotide probes. Appl Environ Microbiol 1998; 64: 3336-3345.

22 Harmsen JHM, Elfferich P, Schut F, Welling GW. A 16S rRNA Targeted probe for detection of lactobacilli and enterococci in faecal samples by fluorescent in situ hybridisation. Micriol Ecol Health Dis 1999; 11: 3-12

23 Manz W, Amann R, Ludwid W, Vancanneyt M, Schleifer KH. Application of a suite of 16S rRNA-specific oligonucleotide probes designed to investigate bacteria of the phylum cytophaga-flavobacter-bacteroides in the natural environment. Microbiology 1996; 142: 1097-1106.

24 Sghir A, Gramet G, Suau A, Rochet V, Pochart P, Dore J. Quantification of bacterial groups within human fecal flora by oligonucleotide probe hybridisation. Appl Environ Microbiol 2000 ; 66: 2263-2266.

25 Poulsen LK, Lan F, Kristensen CS, Hobolth P, Molin S, Krogfelt KA. Spatial distribution of Escherichia coli in the mouse large intestine inferred from rRNA in situ hybridization. Infect Immun 1994; 62: 5191-5194.

26 Aminov RI, Walker AW, Duncan SH, Harmsen HJ, Welling GW, Flint HJ. Molecular Diversity, cultivation, and Improved Detection by fluorescent In Situ Hybridization of a Dominant Group of Human Gut Bacteria Related to Roseburia spp. or Eubacterium rectale. Appl Environ Microbiol 2006: 72: 6371-6376. 
27 Bullock NR, Booth JC, Gibson GR. Comparative composition of bacteria in the human intestinal microflora during remission and active ulcerative colitis. Curr Issues Intest Microbiol 2004; 5: 59-64

28 Van der Waaij LA, Kroese FG, Visser A, Nelis GF, Westerveld BD, Jansen PL et al. Immunoglobulin coating of faecal bacteria in inflammatory bowel disease. Eur J Gastroenterol Hepatol 2004; 16: 669-674.

29 EGRAN. Technical note: Attempts to harmonize chemical analyses of feeds and faeces from rabbit feed evaluation. World Rabbit Science, 2001; 9: 57-64.

30 Flint HJ, Duncan SH, Scott KP, Louis P. Interactions and competition within the microbial community of the human colon:links between diet and health. Environ Microbiol 2007; 9: 1101-1111.

31 Roediger WE. Role of anaerobic bacteria in the metabolic welfare of the colonic mucosa in man. Gut 1980; 21: 793-798.

32 Xu J, Bjursell MK, Himrod J, Deng S, Carmichael LK, Chiang HC et al. A genomic view of the human-Bacteroides thetaiotaomicron symbiosis. Science 2003; 299: 2074-2076.

33 Hamer HM, Jonkers D, Venema K, Vanhoutvin S, Troost FJ, Brummer RJ. Review article: the role of butyrate on colonic function. Aliment Pharmacol Ther 2008 ; 27: 104-119.

34 Collins MD, Lawson PA, Willems A, Cordoba JJ, Fernandez-Garayzabal J, Garcia P et al. The phylogeny of the genus Clostridium: proposal of five new genera and eleven new species combinations. Int J Syst Bacteriol 1994; 44: $812-826$.

35 Pouteau E, Nguyen $P$, Ballèvre $O$, Krempf $M$. Production rates and metabolism of short-chain fatty acids in the colon and whole body using stable isotopes. Proc Nutr Soc 2003; 62: 87-93.

36 Wolever TM, Spadafora PJ, Cunnane SC, Pencharz PB. Propionate inhibits incorporation of colonic [1,2-13C]acetate into plasma lipids in humans. Am J Clin Nutr 1995; 61: 1241-1247.

37 Walker AW, Duncan SH, McWilliam Leitch EC, Child MW, Flint HJ. Ph and peptide supply can radically alter bacterial populations and short-chain fatty acid ratios within microbial communities from the human colon. Appl Environ Microbiol 2005; 71: 3692-3700.

38 Duncan SH, Scott KP, Ramsay AG, Harmsen HJ, Welling GW, Stewart CS et al. Effects of alternative dietary substrates on competition between human colonic bacteria in an anaerobic fermentor system. Appl Environ Microbiol 2003; 69: 1136-1142. 
39 Marschan E, Kuitunen M, Kukkonen K, Poussa T, Sarnesto A, Haahtela T et al. Probiotics in infancy induce protective immune profiles that are characteristic for chronic low-grade inflammation. Clin Exp Allergy 2008. (In press).

40 Peuranen S, Tiihonen K, Apajalahti J, Kettunen A, Saarinen M, Rautonen N. Combination of polydextrose and lactitol affects microbial ecosystem and immune responses in rat gastrointestinal tract. Br J Nutr 2004; 91: 905-914. 
Gut microbiota composition is associated with body weight, weight gain and biochemical parameters in pregnant woman

British Journal of Nutrition, 2010,104 (1), pp. 83-92

A. Santacruz ${ }^{1}$, M. C. Collado ${ }^{1}$, L. García-Valdés ${ }^{2}$, M. T. Segura ${ }^{2}$, J. A. MartínLagos $^{2}$, T. Anjos ${ }^{2}$, M. Martí-Romero ${ }^{3}$, R. M. Lopez 3 , J. Florido ${ }^{3}$, C. Campoy ${ }^{2}$, Y. Sanz ${ }^{* 1}$

${ }^{1}$ Microbial Ecophysiology and Nutrition Group. Institute of Agrochemistry and Food Technology (IATA), Spanish National Research Council (CSIC), Valencia, Spain. ${ }^{2}$ Department of Paediatrics and ${ }^{3}$ Department of Obstetric and Gynecology. School of Medicine. University of Granada. Spain

Running title: Pregnant gut microbiota and overweight

ABSTRACT 
Obesity is associated with complications during pregnancy and increased health risks in the newborn. The objective of this study was to establish possible relationships between gut microbiota, body weight, weight gain, and biochemical parameters in pregnant woman. Fifty pregnant women were classified according to their body mass index (BMI) in normal weight (n 34) and overweight (n 16) groups. Gut microbiota composition was analyzed by quantitative real-time PCR in faeces and biochemical parameters in plasma at 24 weeks of pregnancy. Reduced numbers of Bifidobacterium and Bacteroides and increased numbers of Staphylococcus, Enterobacteriaceae and E. coli were detected in overweight compared to normal weight pregnant women. E. coli numbers were higher in women with excessive weight gain than in woman with normal weight gain during pregnancy, while Bifidobacterium and Akkermansia muciniphila showed an opposite trend. In the whole population, increased total bacteria and Staphylococcus numbers were related to increased plasma cholesterol levels. Increased Bacteroides numbers were related to increased HDL cholesterol and folic acid levels, and reduced triglyceride levels. Increased Bifidobacterium numbers were related to increased folic acid levels. Increased Enterobacteriaceae and E. coli numbers were related to increased ferritin and reduced transferrin, while Bifidobacterium levels showed the opposite trend. Therefore, gut microbiota composition is related to body weight, weight-gain and metabolic biomarkers during pregnancy, which might be of relevance to the management of woman and infant's health. 


\section{INTRODUCTION}

The prevalence of obesity is rapidly increasing worldwide, constituting an important health issue. Obesity is the result of a positive imbalance between energy intake and energy expenditure over a long period and is related to the development of other disorders such as diabetes, dyslipaemia and cardiovascular diseases. Obesity is also associated with complications during pregnancy and at the delivery for women and with increased health risks in newborn ${ }^{(1-3)}$.

There are several genetic and environmental factors such as diet, cultural behaviour, and socioeconomic status, which influence obesity ${ }^{(4,5)}$. In addition, recent reports suggest that the nature and composition of the intestinal microbiota are altered in obesity ${ }^{(6,7)}$. Lean individuals have more Bacteroidetes, while obese individuals have more Firmicutes, including Clostridium clusters, in their intestinal microbiota ${ }^{(6,7)}$. It has been proposed that such bacterial composition improved the ability of the host to extract

energy from the diet and to store this energy in the adipose tissue ${ }^{(7)}$. Gut microbiota has also been related to body weight and body weigh loss under a lifestyle intervention in humans ${ }^{(8,9)}$. Although obesity is an important health issue during pregnancy, the relationships between the gut microbiota composition and obesity has been scarcely studied in pregnant women ${ }^{(10)}$.

The aim of the present study was to analyse the microbiota composition of pregnant women and establish its possible relationships with body weight, 
weight gain and biochemical parameters to progress in the understanding of the role of the microbiota in the health status of pregnant woman.

\section{EXPERIMENTAL METHODS}

\section{Study participants}

The pregnant women were recruited at 20 weeks of pregnancy at the Clinical University Hospital "San Cecilio" de Granada, Spain. Women were classified according to their pre-pregnancy Body Mass Index (BMI) into two groups, overweight women $(\mathrm{n}=16)$ with $\mathrm{BMI}>25$ and normal weight women $(n=34)$ with $B M I<25$ (Table 1). Signed informed consent was obtained from the studied women after a full explanation of the study was given by a member of the team at the first visit. Participants were assured of anonymity and confidentiality. After the visit at the first trimester, women were examined by the obstetrician again at $24\left(2^{\text {nd }}\right.$ trimester $)$ and 34 weeks ( $3^{\text {rd }}$ trimester $)$ and clinical parameters were recorded. At 24 weeks of pregnancy, faecal and blood samples were obtained for microbiological and biochemical analysis. Data on weight before pregnancy was used to calculate weight gain during pregnancy. Normal weight gain ranges were from 11.5 to $16.0 \mathrm{~kg}$ for normal weight women (BMI 19.8-25.0) and from 7.0 to $11.5 \mathrm{~kg}$ for overweight women (BMI $>25$ ), respectively, over pregnancy according to the Institute of Medicine (IOM) criteria ${ }^{(11)}$. Total weight gains above these values, $>16 \mathrm{~kg}$ for normalweight women and $>11.5 \mathrm{~kg}$ for overweight women, were considered 
excessive weight. Data on gestation time and birth weights of the newborns were also collected. This study was conducted according to the guidelines laid down in the Declaration of Helsinki and all procedures involving human subjects were approved by the ethics committee of the Hospital involved in the study. Written informed consent was obtained from all subjects before their inclusion in the study.

\section{Dietary assessment}

Food diary records of pregnant women were kept for $72 \mathrm{~h}$ ( 2 weekdays and 1 weekend day) at 24 weeks of pregnancy. Detailed information on how to record food and drink consumed using common household measures was provided. Food diary records were returned to their dietician, and analyzed for energy, water and nutrient contents based on the CESNID food-composition database of Spanish foods ${ }^{(12)}$.

\section{Biochemical parameters}

Fasting plasma glucose, total cholesterol, HDL cholesterol, triglycerides, urea, creatinine, uric acid, bilirubin and iron were measured by enzyme-colorimetric automated methods for clinical chemistry (Modular analytics EVO, Roche, Neuilly sur Seine Cedex, France). LDL cholesterol was calculated using the Friedwald's formula ${ }^{(13)}$. Ferritin, transferrin, folate and thyroid - stimulating hormone (TSH) levels were measured by using the automatic analyser Elecsys 2010 with modular analytics E170 (Roche, Neuilly sur Seine Cedex, France). 
Table 1. Clinical characteristics of the studied subjects

\begin{tabular}{|c|c|c|c|c|c|}
\hline \multirow[b]{2}{*}{ Characteristics } & \multicolumn{2}{|c|}{$\begin{array}{l}\text { Normal-weight group } \\
\text { (n34) }\end{array}$} & \multicolumn{2}{|c|}{$\begin{array}{l}\text { Overweight group } \\
\qquad(n 16)\end{array}$} & \multirow[b]{2}{*}{$P^{*}$} \\
\hline & Median & IQR & Median & IQR & \\
\hline \multicolumn{6}{|l|}{ Women } \\
\hline Age (years) & 310 & $27.7-34.2$ & 290 & $28.0-33.5$ & 0.646 \\
\hline $\begin{array}{l}\text { Height before pregnancy }(\mathrm{cm}) \\
\text { Weight (kg) }\end{array}$ & 1630 & $158.0-167.0$ & 1620 & $1580-166 \cdot 0$ & 0.967 \\
\hline $\begin{array}{l}\text { Betore pregnancy } \\
\text { First trimester }\end{array}$ & $\begin{array}{l}580 \\
625\end{array}$ & $\begin{array}{l}532-645 \\
58 \cdot 1-66.2\end{array}$ & $\begin{array}{r}730 \\
75-4\end{array}$ & $\begin{array}{l}70 \cdot 0-84.0 \\
71.4-86 \cdot 4\end{array}$ & $\begin{array}{l}>0.001 \\
>0.001\end{array}$ \\
\hline Second trimester (24 weeks) & 664 & $60.7-723$ & 773 & $735-88.6$ & $>0.001$ \\
\hline Third trimester ( 34 weeks) & 704 & $680-755$ & 81.2 & $780-100.0$ & $>0.001$ \\
\hline $\begin{array}{l}\text { Weight gain over pregnancy }(\mathrm{kg}) \\
\text { BMI }\left(\mathrm{kg} / \mathrm{m}^{2}\right)\end{array}$ & 11.7 & $88-14.3$ & 100 & $6.2-11.4$ & 0.120 \\
\hline Betore pregnancy & 230 & $20 \cdot 8-243$ & 28.7 & $263-31 \cdot 2$ & $>0.001$ \\
\hline First trimester & 233 & $21 \cdot 0-25 \cdot 0$ & 290 & $278-32.7$ & $>0.001$ \\
\hline Second trimester (24 weeks) & 240 & $22,7-25 \cdot 7$ & 300 & $268-33.2$ & $>0.001$ \\
\hline Third trimester ( 34 weeks) & 266 & $25 \cdot 1-28.2$ & 308 & $28 \cdot 9-35 \cdot 5$ & $>0.001$ \\
\hline \multicolumn{6}{|l|}{ Newbons } \\
\hline Duration of gestation (weeks) & 390 & $385-400$ & 39.5 & $39 \cdot 0-41 \cdot 0$ & 0.165 \\
\hline Birth weight (kg) & 3.20 & $31-3 \cdot 4$ & 350 & $32-40$ & 0.028 \\
\hline
\end{tabular}

Median values and interquartile ranges (IQR), *Significant differences were calculated using the Mann-Whitney U-test. A significant between was considered at $\mathrm{P}<0.050$

The transferrin saturation index was calculated using the following formula: TSI $(\%)=($ ferritin $(\mathrm{ug} / \mathrm{ml}) .100) /($ transferrin $(\mathrm{mg} / \mathrm{dl}) \times 1.24)$.

\section{Sample preparation and DNA extraction}

Faecal samples were frozen immediately at $-20^{\circ} \mathrm{C}$ and kept until processing. Faeces (1g) were diluted 1: 10 (w/v) in PBS (pH 7.2), homogenized and used for DNA extraction. DNA from pure cultures of reference bacterial strains and faecal samples were extracted using the QIAamp DNA stool Mini kit (Qiagen, Hilden, Germany) following the manufacturer's instructions. The concentration of DNA was determined with a Nanodrop-1000 spectrophotometer (Nanodrop, Wilmington, DE). 


\section{Analysis of faecal microbiota composition}

Quantitative real time PCR (qPCR) was used to characterize the microbiota by using of specific primers targeting different bacterial groups and the SYBR ${ }^{\circledR}$ Green PCR Master Mix (SuperArray Bioscience Corporation, Frederick, MD, USA), as previously described ${ }^{(9,10)}$. PCR amplification and detection were performed with an ABI PRISM 7000-PCR sequence detection system (Applied Biosystems, Warrington, UK). Bacterial concentration from each sample was calculated by comparing the $\mathrm{Ct}$ values obtained from standard curves. Standard curves were created using serial 10-fold dilution of pure culture DNA corresponding to $10^{2}$ to $10^{9}$ cell equivalents $/ \mathrm{ml}$ (genome equivalents $/ \mathrm{ml}$ ). Conversion of the amount of bacteria DNA in samples determined by qPCR to theoretical genome equivalents required the assumption that the genome size and 16S rRNA gene copy number for each bacterial group analyzed was similar. The following genome sizes were used in the study: $2.3 \mathrm{Mb}$ for Bifidobacterium (using B. longum as standard), $2.9 \mathrm{Mb}$ for Lactobacillus (L. casei), $5.2 \mathrm{Mb}$ for Bacteroides (B. fragilis), $4 \mathrm{Mb}$ for $C$. coccoides group, $3.3 \mathrm{Mb}$ for $C$. leptum group, $4.6 \mathrm{Mb}$ for Enterobacteriaceae and E. coli, 2.8 $\mathrm{Mb}$ for Staphylococcus (St. aureus) and $2.7 \mathrm{Mb}$ for Akkermansia muciniphila. Genome sizes were obtained from NCBI data base (Genome project). Standard curves were created using the following reference strains: Bifidobacterium longum subsp. longum CECT 4503, Bacteroides fragilis DSMZ 2451; Clostridium coccoides DSMZ 933; C. leptum DSMZ 935; Staphylococcus aureus CECT 86; Lactobacillus casei ATCC 393; E. coli CECT 45 and Akkermansia muciniphila strain Muc $^{\mathrm{T}}\left(\right.$ ATCC BAA-835 $5^{\mathrm{T}}$ ). 


\section{Statistical analyses}

Statistical analyses were done using the SPSS 11.0 software (SPSS Inc, Chicago, IL, USA). Data distribution was analysed by applying the Kolmogorov-Smirnov test and creating a Gaussian. Due to non-normal distribution, microbial data are expressed as medians with interquartile ranges (IQR). The Mann-Whitney U-test was applied for comparisons between bacterial numbers of normal and overweight women and between women with excessive and normal weight gain over pregnancy. Differences in prevalence of bacterial groups were established by applying the Chi-square test. Correlations between variables were determined by applying the Spearman's rank correlation. A $P<.050$ was considered statistically significant for all tests.

\section{RESULTS}

\section{Body weight, body mass index, and weight gain over pregnancy}

Clinical characteristics of the studied women at recruitment time were similar in both groups (Table 1) except for BMI and body weight. The body weight of the overweight women was significantly higher than that of normal weight women during pregnancy, although no significantly differences $(P=$. 120 ) in weight gain were detected between the groups over time. BMI was significantly different $(P<.050)$ between normal weight and overweight women and increased in both groups over pregnancy. The infants were born at 
term and the infant's birth weight of the overweight women were higher than those of normal weight women $(P=.028)$.

\section{Dietary intakes}

Dietary data of normal weight and overweigh pregnant women at 24 weeks of pregnancy are shown in Table 2. No significant differences in dietary intake of energy, macronutrients or on food group level were found between both groups of women. Only the intake of fiber was slightly higher $(P=.057)$ in normal weight than in overweight woman. When women were grouped according to the total weight gain over pregnancy into two groups (excessive and normal weight gain), no significant differences in dietary intake of energy, macronutrients or on food group level were found between the two groups. No correlations were found between dietary intakes, body weight and body weight gain.

\section{Biochemical parameters}

Biochemical parameters of pregnant women at 24 weeks subdivided according to their BMI in normal and overweight women are shown in Table 3. Bilirubin, iron and folic acid levels were significantly higher in normal than in overweight women $(P=.021, P=.021$ and $P=.042$, respectively).

Table 2. Daily energy and nutrient intake in normal and overweight women at 24 weeks of pregnancy. 


\begin{tabular}{|c|c|c|c|c|c|}
\hline & \multicolumn{2}{|c|}{$\begin{array}{c}\text { Nomal-weight group } \\
\left(18<\mathrm{BMI}<25 \mathrm{~kg} / \mathrm{m}^{2}\right)(n 34)\end{array}$} & \multicolumn{2}{|c|}{$\begin{array}{l}\text { Overweight group } \\
\left(\mathrm{BMI}>25 \mathrm{~kg} / \mathrm{m}^{2}\right)(n \text { 16) }\end{array}$} & \multirow[b]{2}{*}{$P^{*}$} \\
\hline & Medan & IQR & Medan & $\operatorname{IQR}$ & \\
\hline $\begin{array}{l}\text { Energy }(\mathrm{kJ}) \\
\text { Water }(g)\end{array}$ & $\begin{array}{l}886 \\
840\end{array}$ & $\begin{array}{l}7 \cdot 85-10 \cdot 16 \\
6 \cdot 47-11 \cdot 17\end{array}$ & $\begin{array}{l}8.06 \\
8.02\end{array}$ & $\begin{array}{l}6 \cdot 68-9 \cdot 74 \\
7.27-12.31\end{array}$ & $\begin{array}{l}0.430 \\
1.000\end{array}$ \\
\hline $\begin{array}{l}\text { Protein }(9) \\
\text { Protein }(\%)\end{array}$ & $\begin{array}{l}82 \cdot 14 \\
1631\end{array}$ & $\begin{array}{l}73 \cdot 0-99 \cdot 0 \\
14 \cdot 7-177\end{array}$ & $\begin{array}{l}8654 \\
1753\end{array}$ & $\begin{array}{l}75 \cdot 0-103 \cdot 0 \\
15 \cdot 2-20 \cdot 1\end{array}$ & $\begin{array}{l}0.610 \\
0.265\end{array}$ \\
\hline $\begin{array}{l}\text { Plant protein }(g) \\
\text { Plant protein }(\%)\end{array}$ & $\begin{array}{r}25.04 \\
4.73\end{array}$ & $\begin{array}{l}22 \cdot 7-28 \cdot 7 \\
4 \cdot 4-7 \cdot 2\end{array}$ & $\begin{array}{r}23.22 \\
490\end{array}$ & $\begin{array}{c}16.4-26.5 \\
3.5-5.1\end{array}$ & $\begin{array}{l}0.265 \\
0.458\end{array}$ \\
\hline $\begin{array}{l}\text { Animal protein }(g) \\
\text { Animal protein }(\%)\end{array}$ & $\begin{array}{l}5685 \\
11.77\end{array}$ & $\begin{array}{r}48.3-71.7 \\
9.9-12.7\end{array}$ & $\begin{array}{l}61.25 \\
13.15\end{array}$ & $\begin{array}{l}50 \cdot 6-748 \\
10 \cdot 3-15.7\end{array}$ & $\begin{array}{l}0.546 \\
0.063\end{array}$ \\
\hline $\begin{array}{l}\text { Fat }(g) \\
\text { Energy from tat }(\%)\end{array}$ & $\begin{array}{l}91.35 \\
40.28\end{array}$ & $\begin{array}{l}75 \cdot 4-105 \cdot 0 \\
35 \cdot 8-44.7\end{array}$ & $\begin{array}{l}8500 \\
4031\end{array}$ & $\begin{array}{l}62 \cdot 5-105 \cdot 0 \\
33 \cdot 5-443\end{array}$ & $\begin{array}{l}0.458 \\
0.926\end{array}$ \\
\hline $\begin{array}{l}\text { Saturated fat }(g) \\
\text { Energy from satuated fat }(\%)\end{array}$ & $\begin{array}{l}30.36 \\
13.77\end{array}$ & $\begin{array}{l}27 \cdot 1-40 \cdot 4 \\
12 \cdot 2-149\end{array}$ & $\begin{array}{l}26.71 \\
1333\end{array}$ & $\begin{array}{l}20 \cdot 1-420 \\
10 \cdot 0-176\end{array}$ & $\begin{array}{l}0.577 \\
0.963\end{array}$ \\
\hline $\begin{array}{l}\text { MUFA }(g) \\
\text { Energy from MUFA }(\%)\end{array}$ & $\begin{array}{l}37.20 \\
16.23\end{array}$ & $\begin{array}{l}30.0-48.5 \\
14.0-20.0\end{array}$ & $\begin{array}{l}3434 \\
16.00\end{array}$ & $\begin{array}{l}27 \cdot 4-41 \cdot 0 \\
15 \cdot 1-17 \cdot 7\end{array}$ & $\begin{array}{l}0.577 \\
0.889\end{array}$ \\
\hline $\begin{array}{l}\text { PUFA (g) } \\
\text { Energy from PUFA }(\%)\end{array}$ & $\begin{array}{c}1388 \\
58\end{array}$ & $\begin{array}{c}11 \cdot 2-16.4 \\
4.8-73\end{array}$ & $\begin{array}{r}1200 \\
556\end{array}$ & $\begin{array}{l}9 \cdot 2-16 \cdot 7 \\
4 \cdot 4-6 \cdot 5\end{array}$ & $\begin{array}{l}0.458 \\
0.642\end{array}$ \\
\hline $\begin{array}{l}\text { Chdesterol (mg) } \\
\mathrm{CHO}(\mathrm{g})\end{array}$ & $\begin{array}{l}279.70 \\
227.70\end{array}$ & $\begin{array}{r}228.5-4148 \\
200-2620\end{array}$ & $\begin{array}{l}352-46 \\
19700\end{array}$ & $\begin{array}{l}222 \cdot 1-4785 \\
171 \cdot 8-262.7\end{array}$ & $\begin{array}{l}0.458 \\
0.330\end{array}$ \\
\hline $\begin{array}{l}\text { Energy from } \mathrm{CHO}(\%) \\
\text { Simple } \mathrm{CHO}(g)\end{array}$ & $\begin{array}{r}4306 \\
125.20\end{array}$ & $\begin{array}{c}38.0-483 \\
111.8-1533\end{array}$ & $\begin{array}{r}42-43 \\
102.12\end{array}$ & $\begin{array}{l}38 \cdot 0-45 \cdot 1 \\
79 \cdot 0-139 \cdot 5\end{array}$ & $\begin{array}{l}0.610 \\
0.150\end{array}$ \\
\hline $\begin{array}{l}\text { Energy from simple } \mathrm{CHO}(\%) \\
\text { Complex } \mathrm{CHO}(g)\end{array}$ & $\begin{array}{r}2202 \\
10151\end{array}$ & $\begin{array}{l}19 \cdot 5-270 \\
87 \cdot 5-1108\end{array}$ & $\begin{array}{l}21.23 \\
9800\end{array}$ & $\begin{array}{l}18 \cdot 6-23.2 \\
74 \cdot 8-120.2\end{array}$ & $\begin{array}{l}0.280 \\
0.889\end{array}$ \\
\hline Energy from complex $\mathrm{CHO}(\%)$ & 1860 & $17 \cdot 0-24 \cdot 1$ & $20-45$ & $17 \cdot 0-23-4$ & 0.816 \\
\hline Dietary fibre $(g)$ & 1981 & $16 \cdot 2-243$ & 16.75 & $13 \cdot 6-19.0$ & 0.057 \\
\hline
\end{tabular}

Median values and interquartile ranges (IQR). CHO, Carbohydrates

*Statistical significant differences were calculated by using the Mann-Whitney $U$. A significant difference between the groups was considered at $P<0.050$

HDL cholesterol was higher $(P=.050)$ in normal than in overweight women, whereas total cholesterol and triglycerides levels were significantly higher in overweight than in normal weight women $(P=.019$ and $P=.034$, respectively). Moreover, increased levels of triglycerides $(\mathrm{R}=0.30, P=.033)$ and total cholesterol $(\mathrm{R}=0.43, P=.002)$ and reduced levels of bilirubin $(\mathrm{R}=$ $0.36, P=.019)$ and iron $(\mathrm{R}=-0.33, P=.019)$ correlated to overweight women. When women were grouped according to the total weight gain over pregnancy into two groups (excessive and normal weight gain), correlations with some biochemical parameters were also detected. Increased levels of total cholesterol $(\mathrm{R}=0.33, P=.020)$ and ferritin $(\mathrm{R}=0.45, P=.001)$ correlated with women with excessive weight gain over pregnancy. 
Table 3. Biochemical parameters recorded at 24 weeks of pregnancy of normal-weight $\left(\mathrm{BMI}<25 \mathrm{~kg} / \mathrm{m}^{2}\right)$ and overweight women. ( $\mathrm{IBM}>25 \mathrm{~kg} / \mathrm{m}^{2}$ )

\begin{tabular}{|c|c|c|c|c|c|c|}
\hline \multirow[b]{2}{*}{ Biochemical parameter } & \multirow[b]{2}{*}{ Reterence vaiue } & \multicolumn{2}{|c|}{ Normal-wsight group ( $n 34)$} & \multicolumn{2}{|c|}{ Overweight group ( $n$ 16) } & \multirow[b]{2}{*}{$p^{*}$} \\
\hline & & Median & IQR & Median & IQR & \\
\hline Glucoee (mgl) & $650-1100$ & 765 & $697-810$ & 770 & $635-900$ & 0840 \\
\hline Urea $(m g /)$ & $100-500$ & 200 & $175-256$ & 197 & $147-227$ & 0.288 \\
\hline $\begin{array}{l}\text { Crealinine (mg/l) } \\
\text { Uric acid (mgl) }\end{array}$ & $\begin{array}{r}5-12 \\
24-70\end{array}$ & $\begin{array}{r}6 \\
31\end{array}$ & $\begin{array}{c}5-7 \\
27-37\end{array}$ & $\begin{array}{r}5 \\
33\end{array}$ & $\begin{array}{c}5-6 \\
29-37\end{array}$ & $\begin{array}{l}0.072 \\
0.493\end{array}$ \\
\hline $\begin{array}{l}\text { Biinubin (mgl) } \\
\text { Cholesterol (mg, }\end{array}$ & $\begin{array}{c}0-10 \\
1200-2200\end{array}$ & $\begin{array}{r}2 \\
2330\end{array}$ & $\begin{array}{c}2-3 \\
2087-2560\end{array}$ & $\begin{array}{r}1 \\
2590\end{array}$ & $\begin{array}{c}1-3 \\
2300-2810\end{array}$ & $\begin{array}{l}0.021 \\
0.019\end{array}$ \\
\hline $\operatorname{TAG}(\mathrm{mg} /)$ & $500-1700$ & 1480 & $1190-1860$ & 1920 & $1630-2250$ & 0.034 \\
\hline HDL-cholesterd (mgl) & $450-650$ & 770 & $697-955$ & 660 & $580-830$ & 0.050 \\
\hline LDL-cholesterol (mgl) & $500-1500$ & 1350 & $997-1500$ & 1300 & $990-1380$ & 0.580 \\
\hline Total protein $(9 /)$ & $65-87$ & 70 & $66-71$ & 70 & $67-71$ & 0.502 \\
\hline Albumn $(g / 9)$ & $35-50$ & 40 & $37-41$ & 38 & $36-40$ & 0,395 \\
\hline $\mathrm{Fe}(\mu g /)$ & $450-1500$ & 795 & $637-1057$ & 600 & $530-960$ & 0.021 \\
\hline Ferritin $(n g / m)$ & $30-400$ & 190 & $105-31.2$ & 200 & $163-33.7$ & 0356 \\
\hline Transterrin $(m g /)$ & $2120-3600$ & 3585 & $3207-4130$ & 3500 & $3050-3970$ & 0.288 \\
\hline Saturation transterrin index $(\%)$ & $17 \cdot 1-30 \cdot 6$ & 18.7 & $140-250$ & 165 & $116-23.0$ & 0,362 \\
\hline Folic add $(\mathrm{hg} / \mathrm{m})$ & $3 \cdot 1-17 \cdot 5$ & 153 & $106-185$ & 10.5 & $73-17 \cdot 0$ & 0.042 \\
\hline $\mathrm{TSH}(\mu \mathrm{UVm})$ & $03-4.2$ & 1.4 & $0.9-1.7$ & 1.6 & $10-1.6$ & 0.368 \\
\hline
\end{tabular}

Median values and interquartile ranges (IQR) TSH, thyroid-stimulating hormone

* Statistical differences were calculated using the Mann-Whitney $U$ test. A significant difference between the group was considered at $P<.050$.

\section{Microbiota composition in normal and overweight women}

The bacterial numbers detected in faecal samples of normal- and overweight women are shown in Table 4. Bifidobacterium and Bacteroides numbers were significantly higher $(P>.001$ and $P=.035$, respectively $)$ in normal weight women than in overweight women, whereas Enterobacteriaceae $(P=.001)$, E. coli $(P=.005)$ and Staphylococcus $(P=$. 006) numbers were lower in normal weight than in overweight women. $C$. coccoides group numbers were slightly higher in overweight women than in normal weight woman, but not significantly $(P=.088)$. The ratio of Bifidobacterium to $C$. coccoides group was significantly higher $(P<.001)$ in normal weight than in overweight women. The ratio of Bifidobacterium to both 
Clostridium groups (C. coccoides plus $C$. leptum) was also significantly higher $(P<.001)$ in normal weight than in overweight women. Increased numbers of Bifidobacterium $(\mathrm{R}=-0.56, P<.001)$ and Bacteroides $(\mathrm{R}=-0.34, P=.020)$ correlated to normal weight women, while a different trend was found for Staphylococcus $(\mathrm{R}=0.67, P=.003)$, Enterobacteriaceae $(\mathrm{R}=0.46, P<.001)$ and $E$. coli $(\mathrm{R}=0.40, P=.004)$ (Fig 1). An increased ratio of Bifidobacterium to $C$. coccoides correlated to lower BMI $(\mathrm{R}=-0.60, P<.001)$. Similarly, an increased Bifidobacterium to $C$. coccoides plus $C$. leptum ratio was positively related to normal weight women $(\mathrm{R}=-0.54, P<.001)$.

Table 4. Bacterial numbers in faecal samples (cell equivalents (genome equivalents) per $\mathrm{g}$ faeces) analysed by quantitative real-time PCR at 24 weeks of pregnancy.

\begin{tabular}{|c|c|c|c|c|c|c|c|}
\hline \multirow[b]{3}{*}{ Microbial groups } & \multicolumn{3}{|c|}{ Normal-weight women ( $n$ 34) } & \multicolumn{3}{|c|}{ Overweight wamen ( $n 16)$} & \multirow[b]{3}{*}{$P^{*}$} \\
\hline & \multirow[b]{2}{*}{ Prevalencet } & \multicolumn{2}{|c|}{$\begin{array}{l}\text { Baclerial numbers } \\
\text { (log gencme } \\
\text { equivaients/g taeces) }\end{array}$} & \multirow[b]{2}{*}{ Prevalencet } & \multicolumn{2}{|c|}{$\begin{array}{l}\text { Bacterial numbers } \\
\text { (log genome } \\
\text { equivalents/g taeces) }\end{array}$} & \\
\hline & & Median & IQR & & Median & IQR & \\
\hline Total cell ccunts & $34 / 34$ & 985 & $9.40-10 \cdot 24$ & $16 / 16$ & 989 & $9.40-10.02$ & 0.630 \\
\hline Biflobbacterimm & $34 / 34$ & 9.10 & $853-9.52$ & $16 / 16$ & 836 & $7.74-8.57$ & $>0.001$ \\
\hline Lactobaciî́s group & $34 / 34$ & 748 & $735-7 \cdot 60$ & $16 / 16$ & 7.70 & $7 \cdot 40-7.78$ & 0.053 \\
\hline Clostridium coccobles group & $34 / 34$ & 852 & $7.78-8.87$ & $16 / 16$ & 8.75 & $8.29-9.12$ & 0.088 \\
\hline Closindium ieptum group & $30 / 34$ & 840 & $804-8.78$ & 1416 & 835 & $7 \cdot 37-8.66$ & 0313 \\
\hline Bacteroides & $34 / 34$ & 688 & $6.21-7.23$ & $16 / 16$ & 6.20 & $6.00-6.66$ & 0.035 \\
\hline $\begin{array}{l}\text { Enterobactentacase } \\
\text { Escherichia coli }\end{array}$ & $\begin{array}{l}34 / 34 \\
34 / 34\end{array}$ & $\begin{array}{l}637 \\
5.17\end{array}$ & $\begin{array}{l}6 \cdot 10-6 \cdot 76 \\
468-5.70\end{array}$ & $\begin{array}{l}16 / 16 \\
16 / 16\end{array}$ & $\begin{array}{l}7.23 \\
6.20\end{array}$ & $\begin{array}{l}6 \cdot 65-7 \cdot 90 \\
5 \cdot 50-7 \cdot 14\end{array}$ & $\begin{array}{l}0.001 \\
0.005\end{array}$ \\
\hline Staphyiococcus & $8 / 34$ & 440 & $394-4.74$ & $9 / 16$ & 5.78 & $4 \cdot 83-6 \cdot 37$ & 0.006 \\
\hline Akkermansia mudiniphila & $34 / 34$ & 835 & $756-9.00$ & $16 / 16$ & 850 & $7 \cdot 10-9.45$ & 0.763 \\
\hline
\end{tabular}

Median values and interquartile ranges (IQR)) * Significant differences were calculated by using Mann-Whitney $U$ test. A Significant difference between the groups was considered at $P$ $<.050{ }^{\dagger}{ }^{\dagger}$ Prevalence reflects the number of positive amplifications from total samples analysed by PCR ( $\mathrm{n}=$ number of samples analysed)

\section{Microbiota composition according to weight gain over pregnancy}

Faecal microbiota composition of woman showing normal or excessive weight gain over pregnancy is shown in Table 5. E. coli numbers were significantly higher $(P=.045)$ in women with excessive weight gain than in 
women with normal weight gain over pregnancy. A similar trend was found for Enterobacteriaceae numbers although the differences were not significant $(P=$ .142). Contrary to this tendency, Akkermansia muciniphila and Bifidobacterium numbers were higher $(P=.020$ and $P=.078$, respectively) in women with normal weight gain than in those with excessive weight gain.

Table 5. Bacterial numbers in faecal samples (cell equivalents) per $\mathrm{g}$ faeces) analysed by quantitative real-PCR according to recommend weight gain over pregnancy.

\begin{tabular}{|c|c|c|c|c|c|}
\hline \multirow[b]{3}{*}{ Mocbial grouss } & \multicolumn{2}{|c|}{ Namal weight gain (n 3eyt } & \multicolumn{2}{|c|}{ Exosesine weight gain (s 14 ) } & \multirow[b]{3}{*}{ p } \\
\hline & & 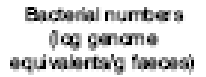 & & 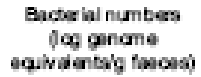 & \\
\hline & Premainnoat & Median (POA) & Prevalerces & Medin (POA) & \\
\hline 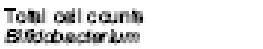 & 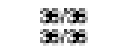 & $\begin{array}{l}990(951-10.25) \\
892(827-9-44)\end{array}$ & 14/14 & $\begin{array}{l}9-73(9-18-1000) \\
8-46(a-13-8-22)\end{array}$ & $\begin{array}{l}0.278 \\
0.078\end{array}$ \\
\hline Lestabeciusgep & E/F & $748(7-39-7-64)$ & $14 / 4$ & $7.66(7-36-7-76)$ & 0.440 \\
\hline Clastriblum cacobibs gep & Ex/s & $871(807-8-97)$ & $14 / 4$ & $835(\theta-15-8 \theta)$ & 0.346 \\
\hline Clostriblum batumgou & $32 / 5$ & $842(816-8-7 a$ & $2 / 14$ & 8. $17(7-20-8-69)$ & 0.209 \\
\hline Soctovabses & SEIS & $642(606-7.09)$ & $14 / 44$ & $6.64(6-20-7.35)$ & $0.39 t$ \\
\hline Enturabectoriacoes & Ex/3 & $656(621-6-86)$ & $14 / 4$ & $6-84(6-16-8.04)$ & $0-14$ \\
\hline Escharichive col & E/As & $526(470-5-94)$ & 14/44 & $6.25(5-06-8.08)$ & 0045 \\
\hline Seppridaxacus & cols & $450(433-5-74)$ & $7 / 4$ & $4+46(4-08-5-82)$ & 0.527 \\
\hline 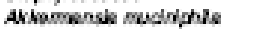 & $3 x$ & $854(7-90-9-50)$ & $14 / 4$ & $8 \cdot 12(6-52-8.50)$ & 0.020 \\
\hline
\end{tabular}

*Significant differences were calculated using Mann-Whitney $U$ test. A significantly difference between the groups was considered at $P<.050$.

$\dagger$ Normal weight gains over pregnancy according to the Institute of Medicine are $<16.0 \mathrm{~kg}$ $\left(\mathrm{BMI}<25 \mathrm{~kg} / \mathrm{m}^{2}\right)$ and $<11.5 \mathrm{~kg}\left(\mathrm{IBM}>25 \mathrm{~kg} / \mathrm{m}^{2}\right)$

Prevalence reflects the number of positive amplifications from total samples analysed by PCR $(\mathrm{n}=$ number of samples analysed) 

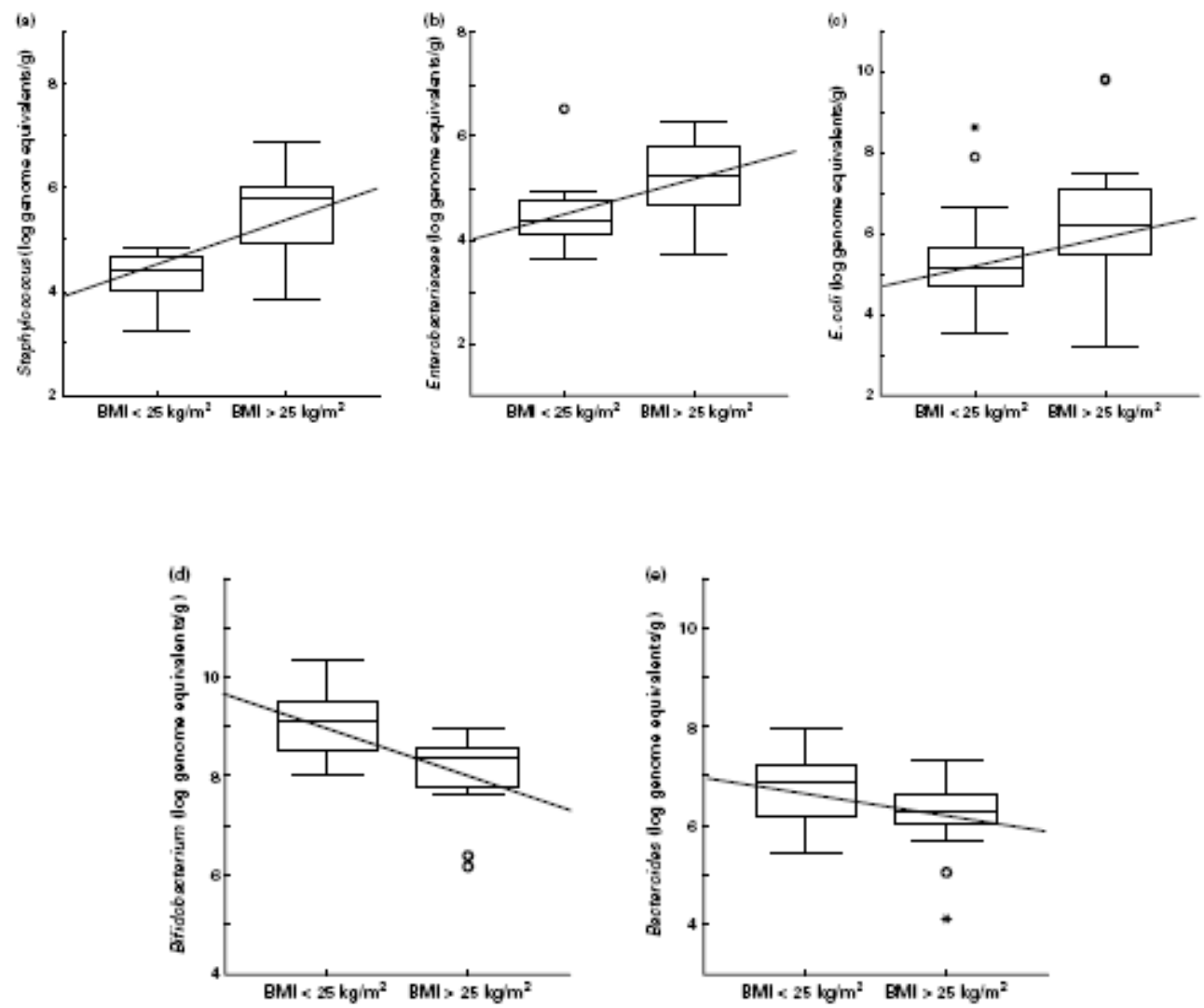

Fig. 1 Relationships between numbers of faecal bacterial groups and weight. Data represent the positive samples. The line in the box is the median $(50 \%$ percentile), with the lower line the lower $25 \%$ border ( $25 \%$ percentile) and the upper line the $75 \%$ ( $75 \%$ percentile) border. The end of the upper vertical line is the maximum data value, outliers not considered. The end of the lower vertical line is the lowest value, outliers not considered. The separate dots or asterisks indicate outliers. Lines showed the Spearman correlation (linear adjustment). (a) Staphylococcus (R-0.67; $P=0.003$ ); (b) Enterobacteriaceae (R0.46; $P<0.001)$; (c) Escherichia coli (R0.40; $P=0.004)$; (d) Bifidobacterium $(\mathrm{R}=0.56 ; \mathrm{P}<0.001)$; (e) Bacteroides (R-0.34; $P=0.020)$ 
The prevalence of C. leptum group and Staphylococcus was higher in women with excessive weight-gain than in women with normal weight gain over pregnancy $(P=.545$ and $P=.124)$. Increased numbers of Bifidobacterium ( $\mathrm{R}=-0.31, P=.029)$, Bacteroides $(\mathrm{R}=-0.36, P=.019)$ and $A$. muciniphila $(\mathrm{R}=-0.34, P=.017)$ correlated significantly to normal weight gain over pregnancy (Fig 2). Opposite, increased numbers of Enterobacteriaceae $(\mathrm{R}=0.28, P=.050)$ and $E$. coli $(\mathrm{R}=0.42, P=.002)$ correlated with excessive weight gain over pregnancy (Fig. 2).

\section{Relationships between microbiota composition and dietary intakes}

In the whole women population, only increased numbers of total bacteria correlated to reduced energy $(R=-0.71 P<.001)$, animal protein $(R=$ $-0.66, P=.001)$, cholesterol $(R=-0.57, P=.007)$ and PUFA $(R=-0.52 P<.015)$ intakes. The same trend was detected between total bacteria and energy $(R=-$ $0.78 P<.001$ and $R=-0.07 P=.002)$, animal protein $(R=-0.61 P<.015$ and $R=$ $-0.75 P=.001)$, and cholesterol $(R=-0.52, P<.043$ and $R=-0.58 P=.018)$ intakes in the normal weight group and in the normal weight gain group. 

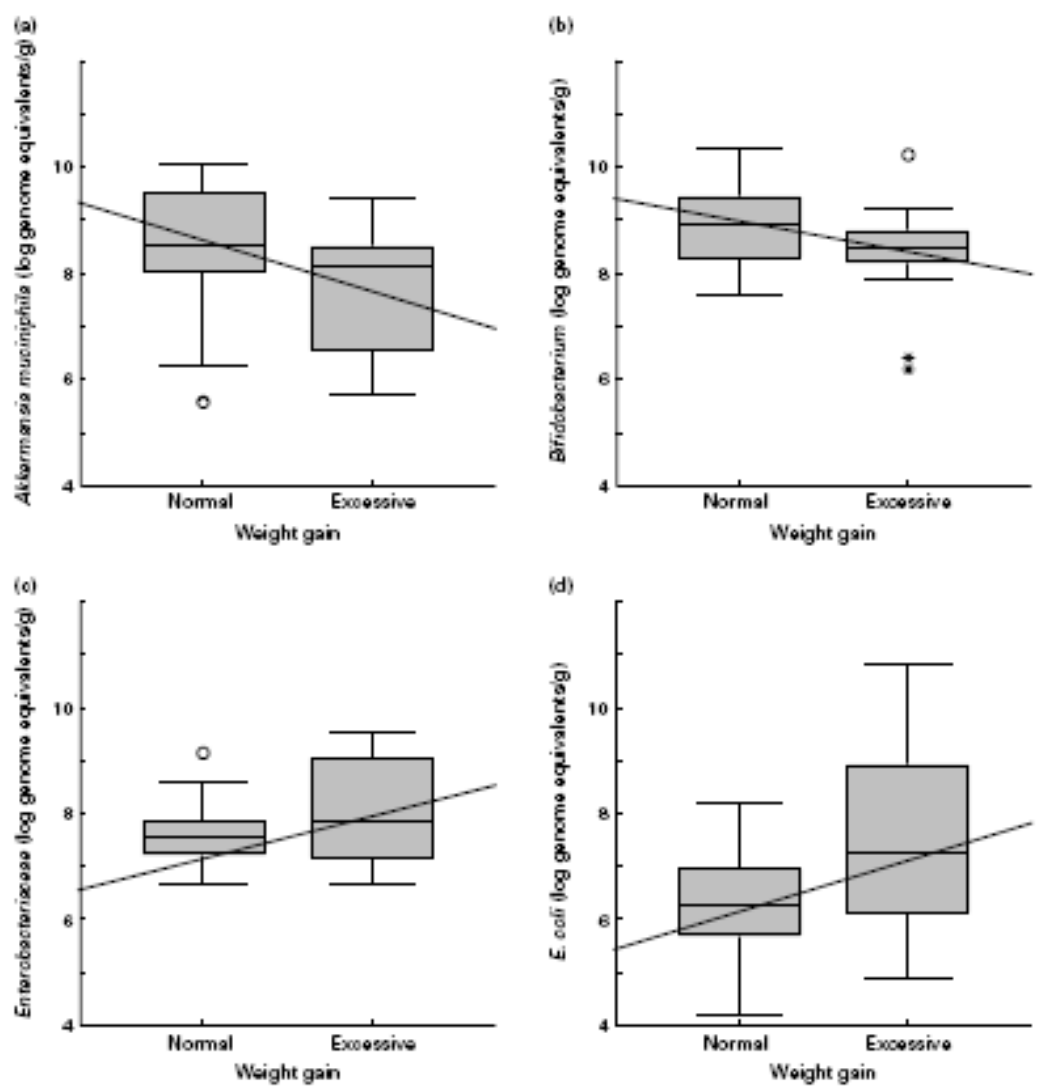

Figure 2. Relationships between numbers of faecal bacterial groups and weight gain over pregnancy. Data represent the positive samples. The line in the box is the median (50\% percentile), with the lower line the lower $25 \%$ border (25\% percentile) and the upper line the 75\% (75\% percentile) border. The end of the upper vertical line is the maximum data value, outliers not considered. The end of the lower vertical line is the lowest value, outliers not considered. The separate dots or asterisks indicate outliers. Lines showed the Spearman correlation (linear adjustment).(a) Akkermansia muciniphila (R0.34; $\mathrm{P}=0.017) ; \quad$ (b) Bifidobacterium $(\mathrm{R}-0 .-31 ; \quad \mathrm{P}=0.029) ; \quad$ (c) Enterobacteriaceae (R-0.28; $\mathrm{P}=0.050) ;$ (d) Escherichia coli $(\mathrm{R}-0.42 ; \mathrm{P}=0.002)$ 


\section{Relationships between microbiota composition and biochemical parameters}

In the whole women population, total bacterial positively correlated to cholesterol $(\mathrm{R}=0.350, P=.013$, respectively). Increased numbers of Staphylococcus were related to increased levels of cholesterol $(\mathrm{R}=0.68, P=$. 003). Increased numbers of Enterobacteriaceae and E. coli counts were significantly correlated to increased levels of ferritin $(\mathrm{R}=0.324, P=.023$ and $\mathrm{R}=0.425, P=.002)$ and saturation transferrin index $(\mathrm{R}=0.302, P=.035$ and $\mathrm{R}=0.439, P=.002)$ and reduced levels of transferrin $(\mathrm{R}=-0.353, P=.013$ and $\mathrm{R}=-0.341, P=.017)$. In contrast, increased numbers of Bifidobacterium were related to reduced levels of ferritin $(\mathrm{R}=-0.420, P=.003)$ and saturation transferrin index $(\mathrm{R}=-0.388, P=.006)$ and to increased levels of transferrin $(\mathrm{R}=0.348, P=.014)$. In addition, increased numbers of Bifidobacterium were related to increased levels of folic acid $(\mathrm{R}=0.308, P=.032)$. Increased numbers of Bacteroides were related to increased levels of HDL cholesterol $(\mathrm{R}=0.518$, $P<.001)$ and folic acid $(\mathrm{R}=0.333, P=.020)$ and to reduced levels of triglycerides $(\mathrm{R}=-0.371, P=.009)$.

In normal weight women, increased numbers of total bacteria correlated to increased levels of cholesterol $(\mathrm{R}=0.383, P=.025)$, while in overweight women the correlations were not significant. In normal weight gain women, increased levels of total bacteria were related to increased levels of total cholesterol $(\mathrm{R}=0.390, P=.019)$, HDL cholesterol $(\mathrm{R}=0.335, P=.046)$ and folic acid $(\mathrm{R}=0.338, P=.044)$. Increased numbers of Staphylococcus correlated with increased levels of total cholesterol $(\mathrm{R}=0.881, P<.001)$. 
Moreover, increased numbers of Bacteroides correlated with higher levels of HDL cholesterol $(\mathrm{R}=0.620, P=.002)$. In women with excessive weight gain over pregnancy, increased numbers of Bifidobacterium were related to increased levels of HDL cholesterol $(\mathrm{R}=0.572, P=.042)$ and reduced levels of total triglycerides $(\mathrm{R}=-0.682, P=.010)$. Increased Bacteroides numbers were related to reduced levels of triglycerides $(\mathrm{R}=-0.809, P=.001)$.

Relationships between maternal microbiota composition and infant's birth weight

In the whole women population, significant positive correlations were found between $E$. coli $(\mathrm{R}=0.331, P=.039)$ and $C$. coccoides $(\mathrm{R}=0.323, P=$. 045) numbers and infant's birth weight were found. In overweight women, positive correlation were also found between $E$. coli numbers and infant's birth weight $(\mathrm{R}=0.673, P=.035)$. In excessive weight gain women, significant negative correlations were found between numbers of Lactobacillus group and infant's birth weight $(\mathrm{R}=-0.917, P=.001)$. 


\section{DISCUSSION}

This study reports differences in the intestinal microbiota of normal weight and overweight pregnant women, associated with body weight and weight gain over pregnancy, suggesting that the intestinal microbiota is a relevant target to weight management in pregnancy. Moreover, newborns form overweight pregnant woman had higher birth weight than those from normal weight pregnant women, suggesting the transference of the mother's features to their newborns. In this context, the results can also be of relevance to the transference of the aberrant microbiota to the newborns, which use the mother's microbiota as inoculums for microbiota development ${ }^{(14)}$. In this context, a positive relationship between the maternal intestinal E. coli numbers and infant's birth weight was demonstrated, which could be related to infant's body weight regulation. In contrast, in excessive weight gain women increased Lactobacillus numbers were related to reduced infant's birth weight, suggesting a positive role of this bacterial group in infant's body weight regulation.

In the present study, increased numbers of Bacteroides, which belong to Bacteroidetes phylum, were detected in normal weight compared to overweight women. In previous studies, the faecal microbiota of lean human subjects was characterized by having increased numbers of Bacteroidetes compared to that of obese subjects. Moreover, weight loss under dietary intervention was associated with increases in Bacteroidetes and Bacteroides 
fragilis group numbers in adults and adolescents ${ }^{(6,8,9)}$. Therefore, the association of Bacteroidetes with a lean phenotype established in previous studies has also been confirmed in pregnant woman included in this study. Nevertheless, Bacteroides numbers were significantly higher in overweight than in normal weight women and associated with excessive weight gain over pregnancy in the only previous study carried out in pregnant women ${ }^{(10)}$. These results contradict all previous findings on the role of Bacteroides in obesity and highlight the importance of the new evidence provided by this study in this regard.

Increased numbers of Bifidobacterium were also related to normal weight women compared to overweight women, and a similar trend was detected in women with normal weight gain compared to those with excessive weight gain over pregnancy. This is in agreement with recent studies, which showed that levels of Bifidobacterium were reduced in infants who developed overweight at 7 years old, compared to normal weight children $^{(14)}$; however, this association was not established in the previous study conducted in pregnant women ${ }^{(10)}$. In animal models, a role has also been attributed to Bifidobacterium in obesity. Obese Zucker rats $(f a / f a)$ and mice fed a high fat diet showed reduced Bifidobacterium counts $(15,16)$. Moreover, the administration of prebiotics to mice fed a high fat diet increased the intestinal Bifidobacterium numbers, which positively correlated with improved glucose tolerance and glucose-induced insulin secretion and with the normalization of the inflammatory tone ${ }^{(16) .}$ 
In addition, the ratio of Bifidobacterium to either $C$. coccoides or to $C$. coccoides plus $C$. leptum group numbers was also significantly higher in normal weight than in overweight women, suggesting a negative role of Clostridium in obesity. In agreement, obese human subjects were shown to have increased numbers of Firmicutes in their faecal microbiota as compared to lean subjects ${ }^{(6)}$. Moreover, weight loss under dietary intervention has also been associated with reduction in Firmicutes or $C$. coccoides and $C$. histolyticum group proportions ${ }^{(6,8,9)}$. Altogether, these results confirm that increases in the relative abundance of members of Firmicutes and, in particular, of some Clostridium clusters is associated with excessive body weight.

Staphylococcus numbers were also increased in overweight compared to normal weight women in agreement with a previous study conducted in pregnant woman ${ }^{(10)}$. Moreover, children becoming overweight at 7 years old showed a greater number of Staphylococcus aureus in faeces during infancy (14). In addition, Enterobacteriaceae and E. coli were significantly higher in overweight than in normal weight women and also in women with excessive weight gain over pregnancy. Increased levels of Gram-negative bacteria, which could include Enterobacteriaceae and E. coli, could be related to the endotoxaemia and inflammatory tone associated with obesity as evidenced in animal models ${ }^{(16) .}$

Total cholesterol and triglycerides levels were significantly higher in overweight than in normal weight women and increased cholesterol levels 
correlated with excessive weight gain over pregnancy, as expected. In addition, folic acid was significantly lower in overweight than in normal weight women, which is a nutrient involved in the correct differentiation of the neural tube during foetal organogenesis. In fact, obesity is a risk factor for neural tube defects ${ }^{(17)}$. Moreover, iron levels were also lower in overweight than in normal weight women and increased levels of ferritin correlated to higher weight gain in the whole population and in the excessive weight gain group. It has been described a relationship between obesity and iron deficiency, which can be reflected in reduced plasma levels of iron and transferrin and increased plasma levels of ferritin and saturation transferrin index ${ }^{(18,19,21,22)}$. The iron deficiency associated with obesity has a multifactorial aetiology and could be due to impairment of intestinal iron uptake and iron release from stores, and to inadequate iron bioavailability because of inflammation. In particular, abnormal ferritin concentrations have been explained by the chronic low-grade inflammation associated with obesity, metabolic syndrome and gestational and type 2 diabetes $(20,21,22)$. Increases in serum ferritin concentrations early in gestation also constitute a risk of gestational diabetes, partly mediated by the maternal fat mass and obesity ${ }^{(22) .}$

This study also reports interesting relationships between biochemical parameters and specific intestinal bacterial groups in pregnant women. While Bacteroides numbers seemed to have a positive effect on plasma biomarkers of lipid metabolism, Staphylococcus numbers seemed to have a negative effect particularly on plasma cholesterol. Cholesterol and other sterols have been shown to stimulate the growth of at least $S$. aureus $^{(23)}$; however, in this study no 
correlation was found between cholesterol intake and Staphylococcus numbers, which could explain a link with plasma cholesterol levels. Other mechanisms have been proposed to justify the influence of the intestinal microbiota on lipid metabolism, including generation of different short-chain fatty acids and regulation of the host gene expression ${ }^{(6,7,24,25)}$ but the specific relationships found in the present study remain to be elucidated.

Bifidobacterium numbers were positively related to plasma folic acid levels in the whole population, which may be due to the ability of some strains of this genus to synthesise and secrete folates in the human intestinal environment, providing a complementary endogenous source of this vitamin (26). This metabolic trait of Bifidobacterium strains could contribute to improving the nutritional status of the pregnant woman and the foetus.

Enterobacteriaceae/E. coli and Bifidobacterium showed inverse relationships with transferrin, saturation transferrin index and ferritin, as well as with body weight in the whole population. Increases in serum transferrin saturation index, because of a transferrin decrease and ferritin increase, have been associated with a decrease of antibacterial activity of serum against enterobacteria, such as Salmonella enterica, which could contribute to favouring the survival of this bacterial group ${ }^{(27)}$. In fact, infections are one of the conditions that can depress transferrin levels. The possibility that the overgrowth of Enterobacteriaceae in the gut environment might favour their translocation to some extent and cause a similar effect could not be disregarded. By contrast, the administration of inulin to pigs led to increased 
Lactobacillus and Bifidobacterium numbers and to up-regulating the expression of genes encoding for iron transporters in the enterocytes, which suggest a connexion between these bacterial groups and/or the prebiotic, and improved iron absorption (28). Therefore, the relative abundance of Bifidobacterium and Enterobacteriaceae may differently influence iron metabolism and, in turn, exert opposite effects on the nutritional status of pregnant woman. Unlikely the present study, a previous report on pregnant woman microbiota did not provide any data on biochemical parameters and their possible associations with the microbiota $^{(10)}$.

In summary, specific bacterial groups are oppositely related to overweight and weight gain during pregnancy, pointing for a beneficial role of Bacteroides and Bifidobacterium in body weight regulation. In addition, novel associations between these bacterial groups and beneficial changes in metabolic biomarkers are provided, suggesting a connexion between the gut microbiota and the host metabolism. Altogether, these findings open new possibilities for the management of body weight and of the nutritional status of pregnant women through modulation of the intestinal microbiota, which may have consequences on later infant's health and deserve further investigations. 


\section{ACKNOWLEDGEMENTS}

This work was supported by grants AGL2008-01440/ALI, Consolider Fun- $C$ Food CSD2007-00063 from the Spanish Ministry of Science and Innovation, AP-124/09 from Consellería de Sanitat (Valencia, Spain) and P06-CTS-02341 (Excellence Project PREOBE) from Consejería de Innovación, Ciencia y Empresa de la Junta de Andalucía. (Spain). A. Santacruz was recipients a scholarship from CONACYT (México) and M.C Collado was recipients of I3P fellowships from CSIC (Spain). Akkermansia muciniphila strain $\mathrm{Muc}^{\mathrm{T}}$ $\left(=\mathrm{ATCC}\right.$ BAA $\left.-835^{\mathrm{T}}=\mathrm{CIP} 107961^{\mathrm{T}}\right)$ was kindly provided by Molecular Microbial Ecology Group, Laboratory of Microbiology, Department of Agrotechnology and Food Sciences, Wageningen University, Wageningen, The Netherlands.

Y. Sanz conceived and coordinated the microbiological study, and draft the manuscript. A. Santacruz and M.C. Collado carried out the microbiological and statistical analyses. C. Campoy coordinate the clinical follow-up of pregnant woman. L García-Valdés, M.T. Segura, J.A. Martín-Lagos and T. Anjos collected clinical and biochemical data. M. Martí-Romero, R.M. Lopez and J. Florido recruited and followed-up pregnant woman. All authors have read, reviewed and approved the final version of the manuscript. The authors do not have any conflict of interest. 


\section{REFERENCES}

1. Ehrenberg HM, Durnwald CP, Catalano P \& Mercer BM (2004) The influence of obesity and diabetes on the risk of cesarean delivery. $\mathrm{Am} \mathrm{J}$ Obstet Gynecol 191, 969-74.

2. Chu SY, Callaghan WM, Kim SY, Schmid CH, Lau J, England LJ \& Dietz PM (2007) Maternal obesity and risk of gestational diabetes mellitus. Diabetes Care 30, 2070-6.

3. Jain NJ, Denk CE, Kruse LK \& Dandolu V (2007) Maternal obesity: can pregnancy weight gain modify risk of selected adverse pregnancy outcomes?. Am J Perinatol 24, 291-8.

4. Hill JO \& Trowbridge FL (1998) Childhood obesity: future directions and research priorities. Pediatrics Supplement: 571.

5. Jouret B, Ahluwalia N, Cristini C, Dupuy M, Nègre-Pages L, Grandjean H \& Tauber M (2007) Factors associated with overweight in preschool-age children in southwestern France. Am J Clin Nutr 85, 1643-9.

6. Ley RE, Turnbaugh PJ, Klein S \& Gordon JI (2006) Microbial ecology: human gut microbes associated with obesity. Nature 444,1022-3.

7. Turnbaugh PJ, Ley RE, Mahowald MA, Magrini V, Mardis ER \& Gordon JI (2006) An obesity-associated gut microbiome with increased capacity for energy harvest. Nature 444, 1027-31.

8. Nadal I, Santacruz A, Marcos A, Warnberg J, Garagorri M, Moreno LA, Martin-Matillas M, Campoy C, Martí A, Moleres A, Delgado M, Veiga OL, García-Fuentes M, Redondo CG \& Sanz Y (2009) Shifts in clostridia, bacteroides and immunoglobulin-coating fecal bacteria associated with weight loss in obese adolescents. Int J Obes (Lond) 33, 758-67.

9. Santacruz A, Marcos A, Wärnberg J, Martí A, Martin-Matillas M, Campoy C, Moreno LA, Veiga O, Redondo-Figuero C, Garagorri JM, Azcona C, Delgado M, García-Fuentes M, Collado MC \& Sanz Y (2009) Interplay Between Weight Loss and Gut Microbiota Composition in Overweight Adolescents. Obesity 23. [Epub ahead of print].

10. Collado MC, Laitinen K, Isolauri E \& Salminen S (2008) Distinct composition of gut microbiota during pregnancy in overweight and normal weight women. Am J Clin Nutr 88, 894-899. 
11. Institute of Medicine. (1990) Nutrition during pregnancy, weight gain and nutrient supplements. Reports of the subcomittee on Nutritional Status and Weight gain during pregnancy. Subcommittee on dietary intake and nutrient supplements during pregnancy and lactation, food and nutrition board. National Academy Press, Washington (DC), 1-233.

12. Farran A, Zamora R \& Cervera P, CESNID (2004) In Tablas de composición de alimentos CESNID, 2nd ed., [Universitat de Barcelona, editor]. Barcelona: McGraw-Hill Interamericana.

13. Friedewald WT, Levy RI \& Fredrickson DS (1972) Estimation of the concentration of low-density lipoprotein cholesterol in plasma, without use of the preparative ultracentrifuge. Clin Chem 18, 499-502.

14. Kalliomäki M, Collado MC, Salminen S \& Isolauri E (2008) Early differences in faecal microbiota composition in children may predict later weight-gain? Am J Clin Nutr 87, 534-538.

15. Waldram A, Holmes E, Wang Y, Rantalainen M, Wilson I, Tuohy K, McCartney A, Gibson G. \& Nicholson J (2009).Top-down systems biology modelling of host metabotype-microbiome associations in obese rodents. $J$ Proteome Res 10, [Epub ahead of print]

16. Cani PD, Neyrinck AM, Fava F, Knauf C, Burcelin RG, Tuohy KM, Gibson GR \& Delzenne NM (2007) Selective increases of bifidobacteria in gut microflora improve high-fat-diet-induced diabetes in mice through a mechanism associated with endotoxaemia. Diabetología 50, 2374-83.

17. Ray JG, Thompson MD, Vermeulen MJ, Meier C, Wyatt PR, Wong PY, Summers AM, Farrell SA \& Cole DE (2007) Metabolic syndrome features and risk of neural tube defects. BMC Pregnancy Childbirth 19,7:21.

18. Nead KG, Halterman JS, Kaczorowski JM, Auinger P \& Weitzman M (2004) Overweight children and adolescents: a risk group for iron deficiency. Pediatrics 114, 104-108.

19. Zimmermann MB, Zeder C, Muthayya S, Winichagoon P, Chaouki N, Aeberli I \& Hurrell RF (2008) Adiposity in women and children from transition countries predicts decreased iron absorption, iron deficiency and a reduced response to iron fortification. Int $J$ Obes (Lond) 32, 1098-1104.

20. Zafon C, Lecube A \& Simó R (2009) Iron in obesity. An ancient micronutrient for a modern disease. Obes Rev. 10. [Epub ahead of print] 
21. Chen X, Scholl TO \& Stein TP (2006) Association of elevated serum ferritin levels and the risk of gestational diabetes mellitus in pregnant women: The Camden study. Diabetes Care 29, 1077-1082.

22. Lecube A. Hernández C, Pelegrí D, et al. (2008) Factors accounting for high ferritin levels in obesity Int J Obes accounting for ferritin levels in obesity Int J Obes (Lond) 32, 1665-1669.

23. Shine WE, Silvany R \& McCulley JP (1993) Relation of cholesterolstimulated Staphylococcus aureus growth to chronic blepharitis. Invest Ophthalmol Vis Sci. 34, 2291-2296.

24. Wolever TMS, Spadafora PJ, Cunnane SC \& Pencharz PB (1995) Propionate inhibits incorporation of colonic [1,2-13C]acetate into plasma lipids in humans. Am J Clin Nutr 61, 1241-1247.

25. Pouteau E, Nguyen P, Ballèvre O \& Krempf M (2003) Production rates and metabolism of short-chain fatty acids in the colon and whole body using stable isotopes. Proc Nutr Soc 62, 87-93.

26. Strozzi GP \& Mogna L (2008) Quantification of folic acid in human feces alter administration of Bifidobacterium probiotic strains. J Clin Gastroenterol 42 Suppl 3 Pt 2, S179-84.

27. Jolivet-Gougeon A, Loréal O, Ingels A, Danic B, Ropert M, BardouJacquet E, Aqodad N, Aussant-Bertel F, Ferec C \& Brissot P (2008) Serum transferrin saturation increase is associated with decrease of antibacterial activity of serum in patients with HFE-related genetic hemochromatosis. Am J Gastroenterol 103, 2502-8.

28. Tako E, Glahn RP, Welch RM, Lei X, Yasuda K \& Miller DD (2008) Dietary inulin affects the expression of intestinal enterocyte iron transporters, receptors and storage protein and alters the microbiota in the pig intestine. Br J Nutr 99, 472-80. 


\title{
Bifidobacterium CECT 7765 improves metabolic and immunological dysfunction associated with obesity in high-fat diet fed mice
}

\author{
Paola Gauffin Cano, Arlette Santacruz, Fernando Trejo, Yolanda Sanz* \\ (Manuscrito enviado)
}
Institute of Agrochemistry and Food Technology, Spanish National Research Council (IATA-CSIC), Valencia, Spain.

Running head: Bifidobacterium CECT 7765 roles in obese mice 


\begin{abstract}
Objective: To evaluate the effects of oral administration of Bifidobacterium pseudocatenulatum CECT 7765 on metabolic and immune dysfunction in mice with high-fat diet (HFD) induced obesity.

Design: Adult (age 6-8 week) male wild-type C57BL-6 mice were fed a standard diet (SD) or HFD, supplemented or not with B. pseudocatenulatum CECT 7765 for seven weeks ( $\mathrm{n} \geq 6$ /group). The following parameters were assessed: animal weight, serum levels of cholesterol, triglyceride, glucose and leptin, liver steatosis, white adipose tissue weight and adipocyte size, lipid micelles per enterocyte, functions of immunocompetent cells (macrophages and dendritic cells [DCs]) and composition and pro-inflammatory properties of the faecal microbiota.
\end{abstract}

Results: B. pseudocatenulatum CECT 7765 administration reduced serum cholesterol, triglyceride and glucose levels by 36,25 and $35 \%$, respectively, in obese mice. This bacterial strain also induced an increase in serum leptin levels in SD-fed mice but a decrease in HFD-fed mice. The administration of $B$. pseudocatenulatum CECT7765 significantly reduced liver steatosis and the number of larger adipocytes (2000 to $4000 \mu \mathrm{m} 2)$ in HFD-fed mice. These effects were associated with reductions in the number of fat micelles in enterocytes, suggesting reductions in dietary fat absorption. The strain also increased the macrophage oxidative burst, the ability of macrophages and DCs to induce cytokines (TNF- $\alpha$ ) in response to pathogenic bacteria (LPS), and the ability of DCs to present antigens and to induce $\mathrm{T}$ lymphocyte proliferation. The bacterial strain also restored the composition of the gut microbiota of HFD-fed mice, increasing Bifidobacterium and reducing Enterobacteriaceae numbers, which altogether led to reducing inflammatory signals coming from the gut.

Conclusion: B. pseudocatenulatum CECT7765 was shown to ameliorate both metabolic and immunological dysfunctions related to obesity in HFD-fed mice. 


\section{INTRODUCTION}

Obesity constitutes a global epidemic nowadays, although its adverse consequences on health have only been seriously considered for the past 10 years. ${ }^{1}$ Obesity is the result of a metabolic energy imbalance and is also characterized by immunological dysfunction and chronic, low-grade inflammation. ${ }^{2}$

Recent scientific evidence supports the notion that the gut microbiota is involved in body weight regulation by influencing metabolic and immunologic functions. ${ }^{3}$ Obesity has also been related to phylum and group-specific changes in the microbiota. Although not all results are consistent ${ }^{4}$, Ley et al. ${ }^{5-6}$ showed that obesity correlates with a decrease in the relative proportion of Bacteroidetes to Firmicutes while weight loss in obese human subjects subjected to dietary intervention correlated to an increase in Bacteroidetes $^{5}$ or the Bacteroides-Prevotella group ${ }^{7}$ proportions. In addition, reduced Bifidobacterium numbers were associated with overweight in pregnant woman by comparisons with normal weight woman. ${ }^{8}$ In genetically obese $f a / f a$ rats, lacking the leptin receptor, associations between decreased Bifidobacterium numbers and obesity have also been reported, suggesting that Bifidobacterium may play a role in defining an obese or lean phenotype. ${ }^{9}$ Therefore, dietary modulation of the intestinal microbiota has been proposed as a way of improving the efficacy of weight-loss treatments ${ }^{3,5,10,11}$. Nevertheless, there is limited knowledge of the obesity-related benefits of bacteria commercialized 
as probiotics (Lactobacillus and Bifidobacterium), particularly, in relation to their potential effects on associated immunological alterations.

The objective of this study was to evaluate the effects of oral administration of Bifidobacterium pseudocatenulatum CECT 7765 on both metabolic and immunological cell functions in mice with high-fat diet induced obesity.

\section{MATERIALS AND METHODS}

\section{Bacterial strains and culture conditions}

The following Lactobacillus and Bifidobacterium strains were studied: L. casei ATCC 393, L. casei IATA-2E11, L. plantarum CECT 4185, L. plantarum 299v (Probi, Lund, Sweden), L. plantarum IATA-L1, L. reuteri IATA-LACA8, B. catenulatum LMG 110437, B. pseudocatenulatum CECT 5776, B. pseudocatenulatum CECT 7765, B. longum IATA-F1, and B. longum BB536 (Morinaga Milk Industry, Zama, Japan). These strains were obtained from the American Type Culture Collection [ATCC], Spanish Type Culture Collection (CECT), Belgian Co-ordinate Collections of Microorganisms (BCCM/LMG), Comercial Química Massó SA, Barcelona, Spain (BB536) or isolated in our laboratory from commercial products $(299 \mathrm{v})$ or from stools of 
breast-fed infants and identified by sequencing of amplified 16S rDNA regions with the primers $27 f$, $530 f$, U-968f previously described ${ }^{12-14}$.

Bacteria were grown in MRS broth (Scharlau, Barcelona, Spain) supplemented with $0.05 \%$ (w/v) cysteine (MRS-C Sigma, St. Louis, MO), and incubated at $37^{\circ} \mathrm{C}$ for $22 \mathrm{~h}$ under anaerobic conditions (AnaeroGen, Oxoid, Basingstoke, UK). Cells were harvested by centrifugation (6.000 g for $15 \mathrm{~min})$, washed twice in phosphate buffered saline (PBS, $130 \pm$ sodium chloride, 10 $\mathrm{mM}$ sodium phosphate, $\mathrm{pH}$ 7.4), and re-suspended in PBS for in vitro stimulation of immunocompetent cells or in $10 \%$ skimmed milk for oral administration to mice. Aliquots of these suspensions were frozen in liquid nitrogen and stored at $-80^{\circ} \mathrm{C}$ until used. The number of live cells after freezing and thawing was determined by colony-forming unit (CFU) counting on MRS$\mathrm{C}$ agar after $48 \mathrm{~h}$ incubation. For each strain tested, more than $90 \%$ cells were alive upon thawing and no significant differences were found during storage time ( 2 months). One fresh aliquot was thawed for every new experiment to avoid variability in the viability of cultures.

\section{Ability of different bacterial strains to induce cytokine production by macrophages}

For evaluating the immunological properties of different Lactobacillus and Bifidobacterium strains, the RAW 264 macrophage cell line, obtained from the American Type Culture Collection (Rockville, MD, USA), was cultured overnight into 24-well flat-bottom polystyrene microtiter plates 
(Corning, Cultek, Madrid, Spain) at a concentration of $1 \times 10^{5}$ cells per $\mathrm{ml}$ in Dulbeco's Modified Eagles Medium (DMEM) (SigmaTM- St. Louis, MO/USA). Media were changed before stimulation and, then, cells were incubated in the presence of $100 \mu \mathrm{l}$ of a cell suspension $\left(1 \times 10^{7} \mathrm{ufc} / \mathrm{ml}\right)$ of each strain for $24 \mathrm{~h}$. Purified LPS from Salmonella enterica serotype Typhimurium (Sigma Chemical Co, Madrid, Spain) was used at a concentration of $1 \mu \mathrm{g} / \mathrm{ml}$ as a positive control. Non-stimulated Raw 264.7 cells were also evaluated as controls of basal cytokine production. The cell culture supernatants were collected and stored at $-20{ }^{\circ} \mathrm{C}$ until used for cytokine determination. TNF- $\alpha$ and MCP-1 were quantified by ELISA Ready SET Go! Kit (BD Bioscience, San Diego, CA, USA). Every parameter was assayed by triplicate in two independent experiments.

\section{Animals, diets and experimental design}

Adult (age 6-8 week) male wild-type C57BL-6 mice were purchased from Harlan Laboratories. In the adaptation period (7 days), all animals were housed in each stainless-steel cage in a temperature-controlled $\left(23{ }^{\circ} \mathrm{C}\right)$ room with a 12-h light/dark cycle and 40-50\% relative humidity and they were fed a standard diet (SD). Then, mice were randomly divided into four groups ( $\mathrm{n} \geq 6$ mice per group) as follows: (1) a control group, that continued receiving the (SD; (2) an obese group, that was switched to a high-fat diet (HFD); (3) a group that continued receiving the SD and a daily dose of $5 \times 10^{8} \mathrm{CFU} B$. pseudocatenulatum CECT 7765 by gavage; and (4) an obese group that was switched to the HFD and a daily dose of $5 \times 10^{8}$ CFU B. pseudocatenulatum 
CECT 7765 by oral gavage. This regime was maintained for seven weeks. The SD (CA.170481 - AIN-76A Purified Diet-Rats/Mice) ) and the HFD (TD.06414 - Adjusted Calories Diet - 60/Fat, Harlan Laboratories, Madison, WI 537444220) were provided by Harlan Laboratories (Madison, WI 53744-4220). The HFD provided $18.4 \% \mathrm{kcal}$ as protein, $21.3 \% \mathrm{kcal}$ as carbohydrate and $60.3 \%$ $\mathrm{kcal}$ as fat $(5.1 \mathrm{kcal} / \mathrm{g})$, whereas the SD provided $18.8 \% \mathrm{kcal}$ as protein, 68.8 $\% \mathrm{kcal}$ as carbohydrate and $12.4 \% \mathrm{kcal}$ as fat $(3.8 \mathrm{kcal} / \mathrm{g})$. Mice had free access to sterile water. Experiments were carried out in strict accordance with the recommendations in the Guide for the Care and Use of Laboratory Animals of University of Valencia (Central Service of Support to Research [SCSIE], University of Valencia, Spain) and the protocol was approved by its Ethic Committee (Body weight was measured once a week and, at the end of study, animals were fasted for $16 \mathrm{~h}$, anaesthetized, bled by aortic puncture and sacrificed by cervical dislocation. For analysis of metabolic parameters, blood samples were collected in tubes containing EDTA and centrifuged to obtain plasma, which was kept at $-20^{\circ} \mathrm{C}$. Faeces were collected initially and at the end of the experimental period (seven weeks) for microbiological analyses. The liver, white adipose (perirenal and epididymal) and small intestinal tissues were excised and rinsed with saline solution, then fixed in $10 \%$ neutral formalin buffered solution for histological analysis.

\section{Histology of liver, white adipose and small intestine tissues}

Paraffin-embedded tissues were sectioned to a thickness of 4-5 $\mu \mathrm{m}$ and fixed to glass slides. Slides were deparaffinized and stained with 
haematoxylin-eosin. The severity of steatosis was determined in 100 hepatocytes of two liver tissue sections per mouse and scored as follows: grade 0 when fat was not detected in hepatocytes; grade 1 when fat occupied less than $30 \%$ of hepatocytes; grade 2 when fat occupied between 30 and $60 \%$ of hepatocytes; grade 3, when fat occupied more than $60 \%$ of hepatocytes.

Adipocyte cell sizes were measured in 100 cells of two sections of epididymal adipose tissue per mouse ${ }^{15}$. Adipocyte cell sizes were expressed as area ranges using the following ranges: < 2000, 2000-4000,4000-6000 and 6000-7000 $\mu \mathrm{m}^{2}$.

The ratio of fat micelles to enterocyte was determined in 100 cells from two sections of small intestine tissue of each mouse by counting ten $100 \mathrm{X}$ light microscope fields. All parameters were measured with a NIKON Eclipse 90i Microscopic, using the NIS Elements BR 2.3 basic research software (Kingston, Surrey, KT2 5PR, UK). All histology analyses were conducted by an experienced histologist in a blind fashion.

\section{Analysis of metabolic parameters}

Serum leptin and insulin concentration was determined by enzymelinked immunosorbent assay (ELISA) (BD Bioscience, San Diego, CA, USA). Biochemical parameters were also quantified in plasma using enzymatic assay kits for glucose (Glucose Liquid Kit; Química Analítica Aplicada SA, Spain), cholesterol (Cholesterol Liquid kit, Química Analítica Aplicada SA, Spain) and triglyceride (Triglyceride Liquid kit, Química Analítica Aplicada SA, Spain). 


\section{Isolation and cytokine production by peritoneal macrophages}

Peritoneal cells were collected by washing the peritoneal cavity of different mouse groups, with $5 \mathrm{ml}$ of sterile cold Dulbeco's Modified Eagles Medium (DMEM) (SigmaTM- St. Louis, MO/USA), containing 10\% inactivated $\left(56^{\circ} \mathrm{C}\right.$ for $30 \mathrm{~min}$ ) foetal bovine serum (FBS) (Gibco, Barcelona, Spain), $100 \mu \mathrm{g} / \mathrm{ml}$ streptomycin and $100 \mathrm{U} / \mathrm{ml}$ penicillin (SigmaTM- St. Louis, $\mathrm{MO} / \mathrm{USA}$ ). Isolated macrophages were plated into flask (Corning, Cultek, Madrid, Spain) at a concentration of $1 \times 10^{6}$ cells per $\mathrm{ml}$ in DMEM and incubated for $2 \mathrm{~h}$ at $37{ }^{\circ} \mathrm{C}$ in an atmosphere containing $5 \% \mathrm{CO}_{2}$, and nonadhered cells were washed out with warm PBS. To evaluate the effects of different stimuli, adhered macrophages were cultured overnight into 24-well flat-bottom polystyrene microtiter plates (Corning, Cultek, Madrid, Spain) at a concentration of $1 \times 10^{5}$ cells per $\mathrm{ml}$ in DEMEN and media were changed before stimulation.

To evaluate the different response to a common stimulus, macrophages from different mouse groups were incubated in the presence of purified LPS from Salmonella enterica serotype Typhimurium (Sigma Chemical Co, Madrid, Spain) at a concentration of $1 \mu \mathrm{g} / \mathrm{ml}$. Non-stimulated peritoneal macrophages were also evaluated as controls of basal cytokine production. To evaluate the immune properties of faecal samples related to the microbiota, macrophages from control mice were incubated in the presence of faecal samples (30 $\mu \mathrm{l}$ of 10-fold dilution) from the different mouse groups for $24 \mathrm{~h}$. Faecal samples used as stimuli were collected from six mice in each 
experimental group at the end of the study, diluted 10-fold in PBS and homogenized for $3 \mathrm{~min}$. The cell culture supernatants were collected and stored at $-20{ }^{\circ} \mathrm{C}$ until used for cytokine determination. TNF- $\alpha$ and IL-10 were quantified by ELISA Ready SET Go! Kit (BD Bioscience, SanDiego, CA, USA). Every parameter was assayed in triplicate in two independent experiments.

\section{Bactericidal activity of peritoneal macrophages}

The bactericidal activity of peritoneal macrophages was analysed according to Vieira et al. ${ }^{16}$ Cells were washed with serum free DMEM and nitroblue tetrazolium (NBT - SigmaTM- St. Louis, MO/USA) at $0.5 \mathrm{mg} / \mathrm{ml}$ together with a bacterial extract (Stimulant, No. 840-15-SigmaTM- St. Louis, MO/USA) in an equivalent concentration of McFarland Scale 2 in Lab-tek chamber slide w/cover (Nalge Nunc International, USA). After $1 \mathrm{~h}$ of incubation at $37{ }^{\circ} \mathrm{C}$ in $5 \% \mathrm{CO} 2$ atmosphere, the cells were washed with PBS, then fixed with $4 \%$ paraformaldehyde and observed with an optic microscope (Kingston, Surrey, KT2 5PR, UK). One hundred cells per mouse were counted and the percentage of NBT positive cells was determined. Every parameter was assayed in triplicate in two independent experiments.

\section{Isolation and cytokine production by bone marrow-derived dendritic cells}

Dendritic cells (DCs) were generated from bone marrow as described previously. ${ }^{17}$ Cells were seeded at a concentration of $1 \times 10^{6}(90-94 \%$ DCs $)$ in 
$1 \mathrm{ml}$ of culture medium without rm GM-CSF in 24-well plates (Corning, Cultek, Madrid, Spain) and incubated in the presence of different stimuli at 37 ${ }^{\circ} \mathrm{C}$ under 5\% CO2 for $24 \mathrm{~h}$. To evaluate the different response to a common stimulus, DCs from different mouse groups were incubated in the presence of purified LPS from Salmonella enterica serotype Typhimurium (Sigma Chemical Co, Madrid, Spain) at a concentration of $1 \mu \mathrm{g} / \mathrm{ml}$. Non-stimulated peritoneal macrophages were also evaluated as controls of basal cytokine production. To evaluate the immune properties of faecal samples related to the microbiota, DCs from control mice were incubated in the presence of faecal samples (30 $\mu$ of 10 -fold dilution) from the different mouse groups. Faecal samples were obtained and prepared as described above. The cell culture supernatants were collected and stored at $-20{ }^{\circ} \mathrm{C}$ until used for cytokine determination (TNF- $\alpha$ and IL-10) as described above. Every parameter was assayed in triplicate in two independent experiments.

\section{Interactions between DCs and T CD4+ lymphocytes}

CD4+ T lymphocytes were isolated from mouse spleens. To do so, spleens were excised, suspended in complete medium and passed through a stainless steel wire mesh, and the crude cell suspension obtained was washed once. CD4+ $\mathrm{T}$ cells were immunomagnetically isolated by positive selection with "CD4+ (L3T4) microbeads" (Miltenyi Biotec GmbH, Bergisch Gladbach, Germany), according to the manufacturer's instructions. CD4+ T cells (purity exceeded 95\%) were used for mixed lymphocyte reaction. Isolated DCs were incubated for $24 \mathrm{~h}$ in the presence of $1 \mu \mathrm{g} / \mathrm{ml}$ LPS from S. typhimurium (Sigma 
Chemical Co, Madrid, Spain). Aliquots of mature DCs from different mouse groups were plated in triplicate with allogeneic CD4+ T cells (TL) at 1:1, 1:2, 1:4, TL / DC cell ratios, in $0.2 \mathrm{ml}$ culture medium in 96-well flat-bottomed plates (Corning, Cultek, Madrid, Spain) at $37{ }^{\circ} \mathrm{C}$ for $72 \mathrm{~h}$. Lymphocyte proliferation was measured with the cell proliferation ELISA BrdUcolorimetric assay (Roche, Diagnostic, Germany). Individual cultures of DCs, and TL stimulated with or without ConA, used as mitogen, were used as controls.

\section{Samples and microbial analysis by quantitative PCR (qPCR)}

Faecal samples were weighed, diluted 1:5 (w/v) in PBS (pH 7.2), homogenized by thorough vortex shaking and stored at $-20{ }^{\circ} \mathrm{C}$ until analysed. One aliquot of this dilution was used for DNA extraction using the QIAamp DNA stool Mini kit (Qiagen, Hilden, Germany). Specific primers (Table 1) 1-22 $^{2}$ targeting different bacterial genera and species were used to characterize the composition of the microbiota by qPCR using LightCycler ${ }^{\circledR} 480$ SYBR Green I Master (Roche, USA) with a an ABI PRISM 7000-PCR sequence detection system (Applied Biosystems, UK), as described previously ${ }^{23}$.

\section{Statistical analyses}

Statistical analyses were carried out using SPSS 11.0 software (SPSS Inc., Chicago, IL, USA). Biochemical parameter data were normally distributed and significant differences were determined by applying a One- 
Way ANOVA with post hoc Tukey's test or Fisher's Least Significant Difference (LSD) test. The rest of data were non-normally distributed and the differences were determined by applying the Mann-Whitney $U$ tests. In every case, $P$-values $<0.05$ were considered statistically significant.

Table 1. Oligonucleotide primers used in this study.

\begin{tabular}{|c|c|c|c|c|}
\hline $\begin{array}{c}\text { Bacterial } \\
\text { groups }\end{array}$ & Sequence $\left(5^{\prime}-3^{\prime}\right)$ & (pb) & $\begin{aligned} \text { Ann. } \\
\left({ }^{\circ} \mathrm{C}\right)\end{aligned}$ & Ref \\
\hline Total bacteria & $\begin{array}{l}\text { TGGCTCAGGACGAACGCTGGCGGC } \\
\text { CCTACTGCTGCCTCCCGTAGGAGT }\end{array}$ & 200 & 59 & (1) \\
\hline Bifidobacterium & $\begin{array}{c}\text { CTCCTGGAAACGGGTGG } \\
\text { GGTGTTCTTCCCGATATCTACA }\end{array}$ & 550 & 55 & $(1,2)$ \\
\hline Bacteroides & $\begin{array}{l}\text { ATA GCC TTT CGA AAG RAA GAT } \\
\text { CCA GTA TCA ACT GCA ATT TTA }\end{array}$ & 287 & 55 & $(1,2)$ \\
\hline $\begin{array}{l}\text { Clostridium } \\
\text { coccoides group }\end{array}$ & $\begin{array}{l}\text { AAA TGA CGG TAC CTG ACT AA } \\
\text { CTT TGA GTT TCA TTC TTG CGA A }\end{array}$ & 440 & 50 & $(1,2)$ \\
\hline $\begin{array}{l}\text { Clostridium leptum } \\
\text { group }\end{array}$ & $\begin{array}{l}\text { GCA CAA GCA GTG GAG T } \\
\text { CTT CCT CCG TTT TGT CAA }\end{array}$ & 239 & 50 & $(1,2)$ \\
\hline Enterobacteriaceae & $\begin{array}{l}\text { CATTGACGTTACCCGCAGAAGAAG } \\
\text { CTCTACGAGACTCAAGCTTGC }\end{array}$ & 195 & 63 & (3) \\
\hline Lactobacillus group & $\begin{array}{l}\text { AGCAGTAGGGAATCTTCCA } \\
\text { ATTYCACCGCTACACATG }\end{array}$ & 340 & 61 & $(4,5)$ \\
\hline
\end{tabular}




\section{RESULTS}

Strain selection based on in vitro ability to induced cytokine production by macrophages.

The results of the effects of different Lactobacillus and Bifidobacterium strains on induction of cytokine production by Raw 264.7 macrophages are shown in Table 2. All strains induced the production of significantly higher amounts of the pro-inflammatory cytokine TNF- $\alpha$ and the chemokine MCP-1 than the non-stimulated cells although the magnitude of the effect was strain-dependent. The only exception was the strain $B$. pseudocatenulatum CECT 7765 that did not significantly induce TNF- $\alpha$ production above control levels. B. pseudocatenulatum CECT 7765 and $B$. longum BB536 also induced significantly lower production of MCP 1 than the other strains studied. B. pseudocatenulatum CECT 7765 was finally selected on the basis of its lower pro-inflammatory potential.

\section{Body and total, epididymal and perirenal adipose tissue weight gain in obese mice}

The HFD-fed mice experienced significant weight gain as compared to the SD-fed mice as of the first two weeks of treatment (Figure 1-A). In the $7^{\text {th }}$ week, the relative body weight increase of HFD-fed mice was $31.0 \pm 10.2 \%$, whereas that of SD-fed mice was $17.7 \pm 8.0 \%$. The administration of $B$. pseudocatenulatum CECT7765 did not significantly alter body weight in either of the groups (SD and HFD). The weight of total and epididymal adipose 
tissues was greater at statistically significant $(P=0.016, P=0.019)$ levels in obese mice than in lean mice (Figure 1-B). The administration of $B$. pseudocatenulatum CECT7765 did not exert a statistically significant effect on total adipose tissue weights, only was observed a slight increase of epididymal adipose tissue weight in SD group (Figure 1-B).

\section{Metabolic parameters in obese mice}

Serum levels of biochemical markers of metabolic relevance are shown in Table 3. The HFD induced a significant increase $(P=0.05)$ in serum cholesterol, triglyceride and glucose levels as compared with the SD. The administration of B. pseudocatenulatum CECT7765 to HFD-fed mice led to a significant $(P=0.05)$ reduction in serum cholesterol, triglyceride and glucose levels of 36, 25 and $35 \%$ as compared to the levels reached in the HFD-fed mouse group not receiving the bifidobacterial strain. Mice receiving HFD became markedly hyperleptinemic $(P=0.001)$ compared to SD-fed mice (Figure 2-A). The administration of B. pseudocatenulatum CECT 7765 induced a significant increase $(P=0.001)$ in leptin levels in SD-fed mice while it significantly $(P=0.035)$ reduced the leptin levels in HFD-fed mice (Figure 2A). In addition, a significant $(P=0.01)$ increase of insulin was observed in HFD compared to SD-fed mice (Figure 2-B), but B. pseudocatenulatum CECT 7765 induced a significant decrease $(P=0.004)$ of insulin levels in HFD mice. 
Table 2. Ability of different Lactobacillus and Bifidobacterium strains to induce cytokine production by RAW264.7 macrophages.

\begin{tabular}{|c|c|c|}
\hline \multirow{2}{*}{ Bacterial strains } & \multicolumn{2}{|c|}{ Cytokine production } \\
\hline & $\begin{array}{l}\text { TNF- } \alpha(p g / m l) \\
\text { Mean (SD)* }\end{array}$ & $\begin{array}{c}\text { MCP 1 (pg/ml) } \\
\text { Mean (SD)* }\end{array}$ \\
\hline Control & $630.0(56.5)$ & $207.1(62.0)$ \\
\hline LPS $(1 \mu \mathrm{g} / \mathrm{ml})$ & $9,987.5(992.4)^{\mathbf{a}, \mathbf{b}}$ & $3,462.0(104.8)^{\mathbf{c}, d}$ \\
\hline L. casei ATCC 393 & $2,420.0(124.7)^{a, b}$ & $1,012.6(19.0)^{\mathbf{c}, \mathbf{d}}$ \\
\hline L. casei IATA-2E11 & $2,121.0(138.5)^{\mathrm{a}, \mathrm{b}}$ & $807.9(20.5)^{\mathbf{c}, \mathbf{d}}$ \\
\hline L. plantarum CECT 4185 & $2,849.5(73.3)^{\mathbf{a}, \mathrm{b}}$ & $1,173.9(18.2)^{\mathrm{c.d}}$ \\
\hline L. plantarum $299 \mathrm{v}$ & $2,725.0(113.1)^{\mathbf{a}, \mathbf{b}}$ & $1,012.6(19.0)^{\mathrm{c}, \mathrm{d}}$ \\
\hline L. plantarum IATA-L1 & $5,907.0(83.1)^{\mathbf{a}, \mathbf{b}}$ & $3,187.1(26.8)^{\mathbf{c}, \mathbf{d}}$ \\
\hline L. reuteri IATA-LACA8 & $3,281.0(80.8)^{\mathbf{a}, \mathbf{b}}$ & $1,297.5(88.3)^{\mathbf{c}, \mathbf{d}}$ \\
\hline B. catenulatum LMG 110437 & $6,126.0(434.1)^{\mathrm{a}, \mathrm{b}}$ & $2,575.4(42.9)^{\mathrm{c}, \mathrm{d}}$ \\
\hline B. pseudocatenulatum CECT 5776 & $8,110.0(215.9)^{\mathbf{a}, \mathbf{b}}$ & $3,069.7(108.6)^{\mathrm{c}, \mathrm{d}}$ \\
\hline B. pseudocatenulatum CECT 7765 & $788.0(39.2)$ & $378.2(25.7)^{\mathrm{C}}$ \\
\hline B. longum IATA-F1 & $7,552.5(10.9)^{\mathbf{a}, \mathbf{b}}$ & $3081.9(13.5)^{c, d}$ \\
\hline B. longum BB536 & $1,593(15.0)^{\mathrm{a}, \mathrm{b}}$ & $443.7(85.3)^{\mathrm{C}}$ \\
\hline
\end{tabular}


*Results are expressed as mean and standard deviation (SD) of duplicate measures determined in three independent experiments. Significant differences were established at $P<0.05$ by applying ANOVA and post hoc Fisher's Least Significant Difference (LSD) test. 'Significant

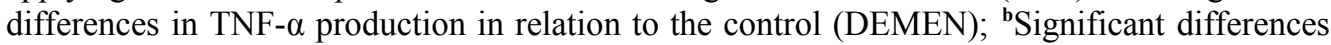
in TNF- $\alpha$ production in relation to B. pseudocatenulatum CECT 5776; 'Significant differences

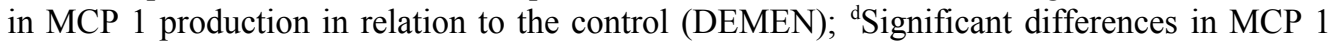
production in rela 1
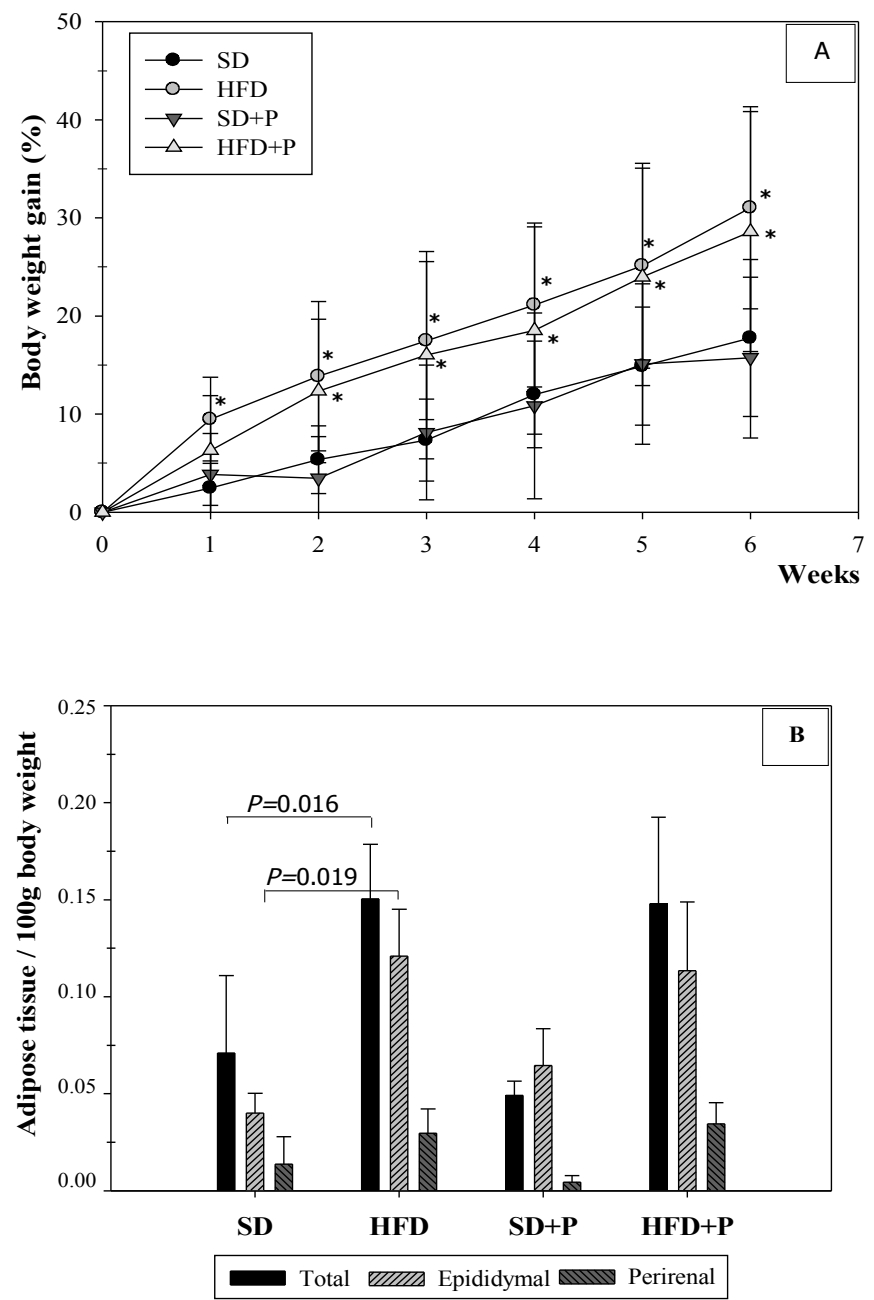
Figure 1. Body weight gain (A) and relative adipose tissue weight (B) in mice fed standard diet or high-fat diet supplemented or not with B. pseudocatenulatum CECT7765. SD: standard diet group (control) $(\mathrm{n}=12)$; $\mathrm{SD}+\mathrm{P}$ : standard diet group receiving a daily dose of $5.0 \times 10^{8}$ CFU/mouse of $B$. pseudocatenulatum CECT7765 by gavage for seven weeks $(n=6)$; HFD:

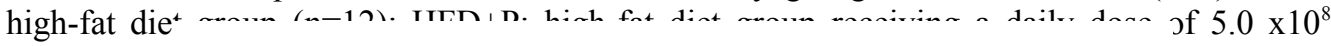
CFU/mouse weighed we as adipose 1 and periren

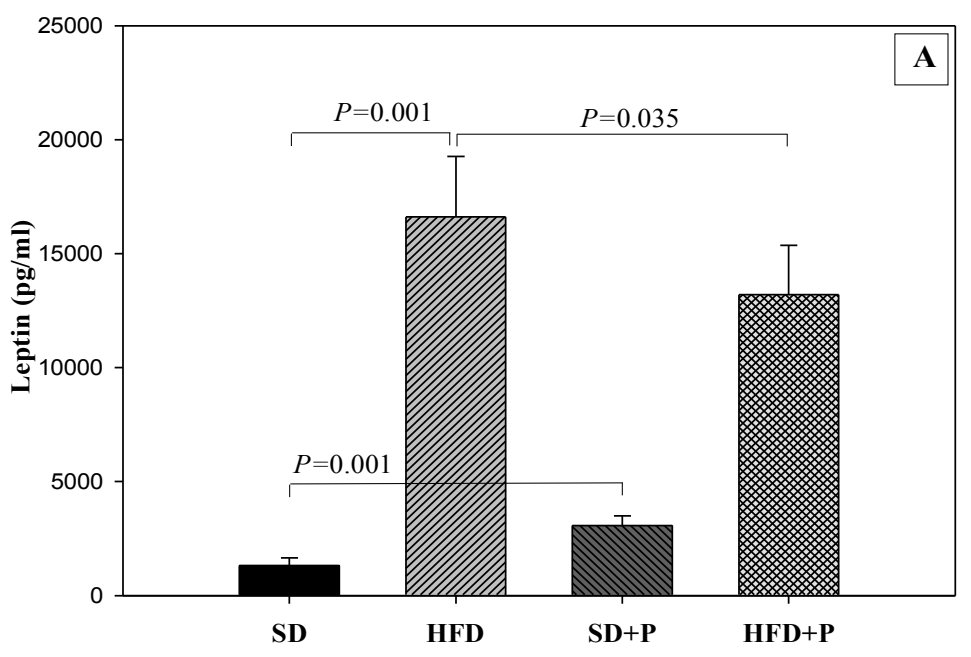
Mice were significant $c$ ; expressed epididymal statistically

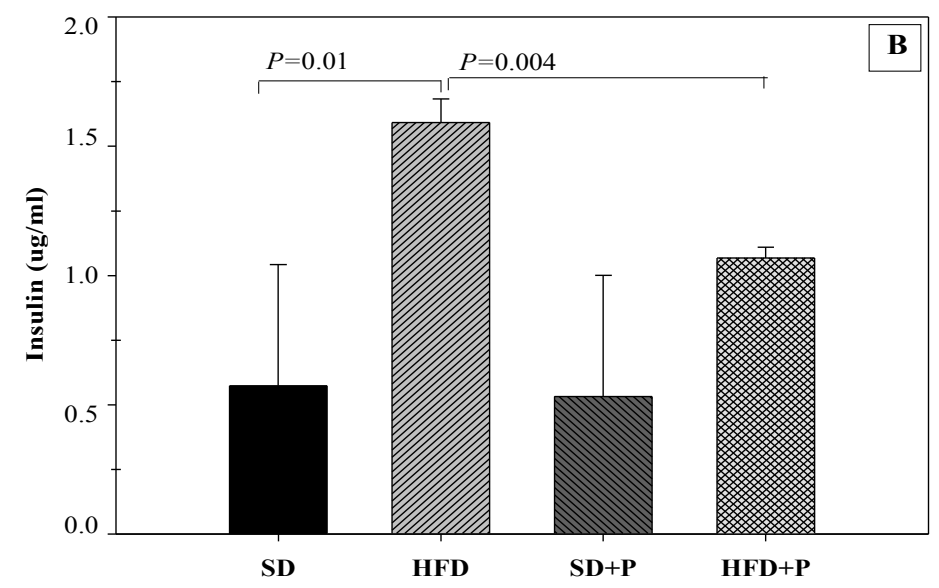


Figure 2. Determination of leptin (A) and insulin (B) levels in mice fed a standard diet (SD) or a high-fat diet (HFD), supplemented or not with B. pseudocatenulatum CECT7765. SD: standard diet group (control) $(\mathrm{n}=6)$; $\mathrm{SD}+\mathrm{P}$ : standard diet group receiving a daily dose of 5.0 $\mathrm{x} 10^{8} \mathrm{CFU} / \mathrm{mouse}$ of $B$. pseudocatenulatum CECT7765 by gavage for seven weeks $(\mathrm{n}=6)$; HFD: high-fat diet group $(\mathrm{n}=6)$; HFD+P: high-fat diet group receiving a daily dose of 5.0x $10^{8}$ $\mathrm{CFU} /$ mouse of $B$. pseudocatenulatum CECT7765 by gavage for seven weeks $(n=6)$. Data are expressed as means \pm SD and statistically significant differences are established at $P<0.05$.

Hepatic steatosis, adipocyte size, and fat absorption by enterocytes in obese mice

Steatosis and significant increases in the number of hepatocytes with grades $3(P=0.008)$ and $2(P=0.018)$ steatosis resulted from the HFD, while hepatocytes with no steatosis or grade-1 $(P=0.013)$ steatosis decreased (Figure 3-A). B. pseudocatenulatum CECT 7765 significantly reduced steatosis in HFD-fed mice, but did not influence this parameter significantly in mice fed the SD. B. pseudocatenulatum CECT7765 administration reduced the number of hepatocytes with grade-3 steatosis $(P=0.013)$ and increased those with grades $1(P=0.018)$ and $2(P=0.018)$ steatosis in HFD-fed mice. 
The effects of the diets, supplemented or not with $B$. pseudocatenulatum, on adipose tissue (epididymal and perirenal) weight and adipocyte size in epididymal adipose tissue are shown in Figures 1B and 4, respectively. The HFD induced increases in on adipose tissue (epididymal and perirenal) weight ( $P=0.019$ and $P=0.016$, respectively) but the administration of B. pseudocatenulatum CECT7765 did not significantly modified these effects. The HFD induced significant increases in the adipocytes in the size ranges 2000-4000 $(P=0.018)$ and 4000-6000 $\mu \mathrm{m} 2(P=0.018)$ and reductions in those $\leq 2000 \mu \mathrm{m} 2(P=0.018)$. B. pseudocatenulatum CECT7765 administration in SD-fed mice did not induce significant modifications in adipocyte size, while in HFD-fed mice it led to a significant decrease $(P=0.018)$ in the number of larger adipocytes (2000 to $4000 \mu \mathrm{m} 2)$ and an increase in the number of smaller adipocytes $(<2000 \mu \mathrm{m} 2)$ (Figure 4-A)
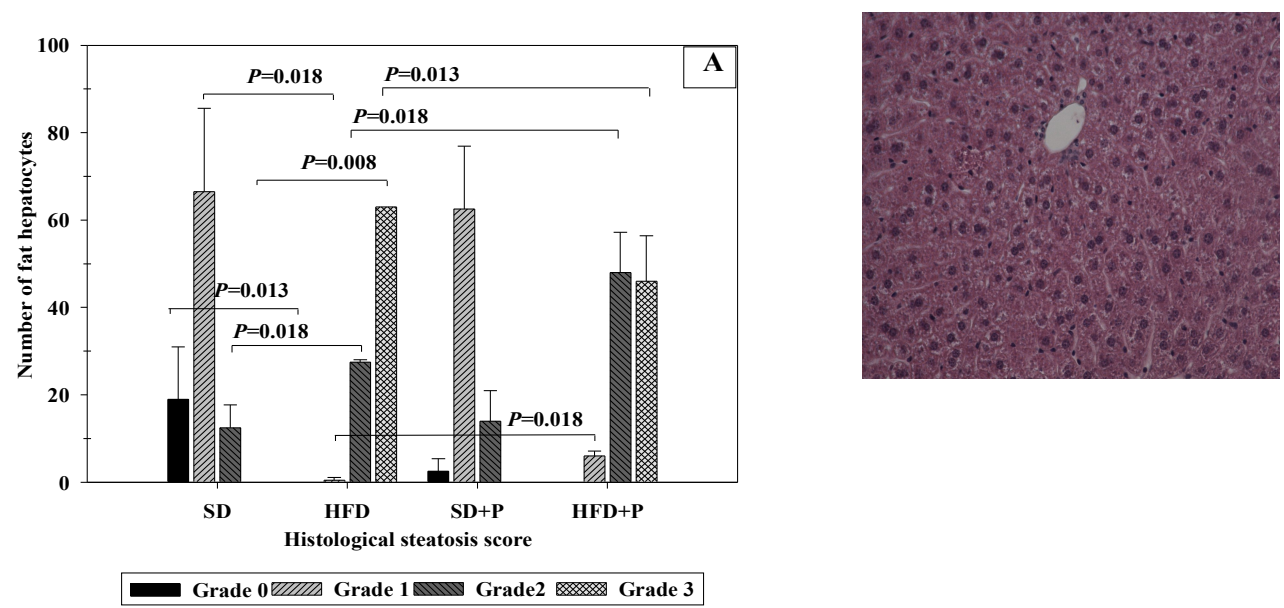

142
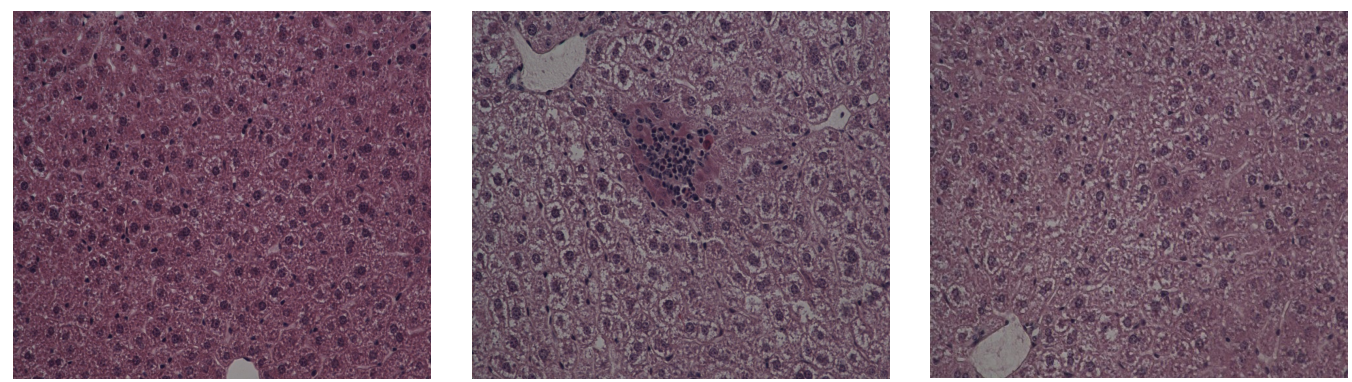
Figure 3. Determination of hepatic steatosis (hepatic histology) in mice fed standard diet or high-fat diet, supplemented or not with B. pseudocatenulatum CECT7765. SD: standard diet group (control) $(\mathrm{n}=6)$; $\mathrm{SD}+\mathrm{P}$ : standard diet group receiving a daily dose of $5.0 \times 10^{8}$ CFU/mouse of $B$. pseudocatenulatum CECT7765 by gavage for seven weeks ( $n=6)$; HFD: high-fat diet group $(\mathrm{n}=6)$; HFD+P: high-fat diet group receiving a daily dose of $5.0 \times 10^{8}$ CFU/mouse of B. pseudocatenulatum CECT7765 by gavage for seven weeks $(n=6)$. The fat vacuoles were measured in 100 hepatocytes of two liver tissue sections per mouse and scored for the severity of steatosis according to the following criteria: For grade- 0 steatosis, no fatty hepatocytes; grade-1 steatosis, fat occupying less than $30 \%$ of the hepatocyte; grade-2

steatosis, fat occu more than $60 \%$

significant differe stained slides are group. osis, fat occupying $\mathrm{J}$ and statistically representative HEp and (F) HFD+P
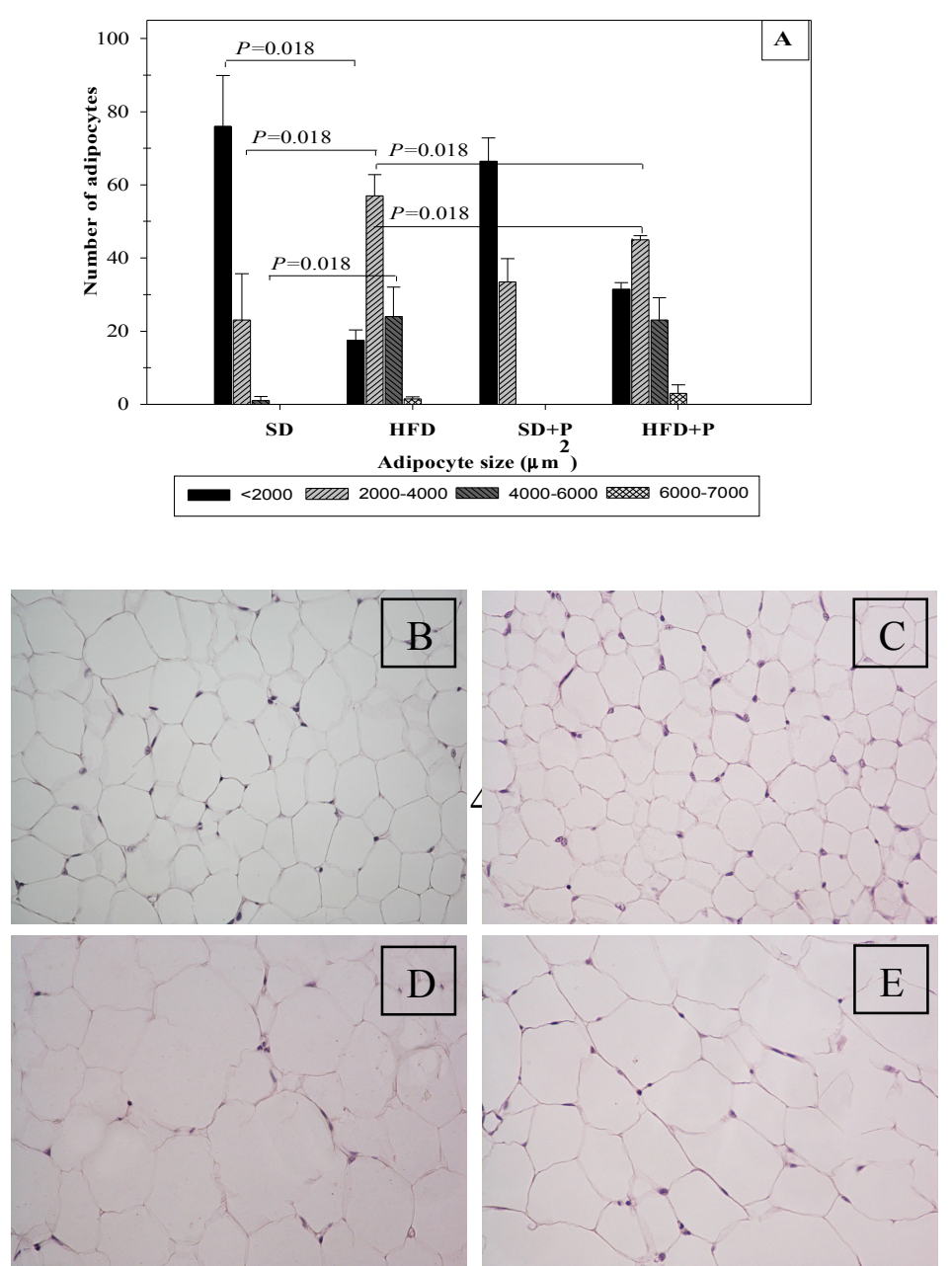
Figure 4. Distribution of adipocyte size in epididymal adipose tissue in mice fed a standard diet or a high-fat diet, supplemented or not with B. pseudocatenulatum CECT7765. SD: standard diet group (control) $(\mathrm{n}=6)$; $\mathrm{SD}+\mathrm{P}$ : standard diet group receiving a daily dose of 5.0 $\mathrm{x} 10^{8} \mathrm{CFU} /$ mouse of $B$. pseudocatenulatum CECT7765 by gavage for seven weeks $(\mathrm{n}=6)$; HFD: high-fat diet group ( $\mathrm{n}=6)$; HFD+P: high-fat diet group receiving a daily dose of 5.0x $10^{8}$ $\mathrm{CFU} /$ mouse of $B$. pseudocatenulatum CECT7765 by gavage for seven weeks $(\mathrm{n}=6)$. Adipocyte cell sizes are expressed as area ranges as follows: $<2000,2000-4000,4000-6000$ and $6000-$ $7000 \mu \mathrm{m}^{2}$. Data are expressed as means \pm SD and statistically significant differences are established at $P<0.05$. Photomicrographs $20 \mathrm{X}$ of representative HE-stained slides are shown. (B) SD group, (C) SD+P group, (D) HFD group and (E) HFD+P group. The effects of the HFD and B. pseudocatenulatum CECT7765 administration on the number of fat micelles per enterocyte, indicating dietary fat absorption, are shown in Figure 5. The HFD induced a significant increase $(P=0.018)$ in the number of fat micelles in the enterocytes, whereas the administration of $B$. pseudocatenulatum CECT7765 reduced $(P=0.018)$ these numbers.

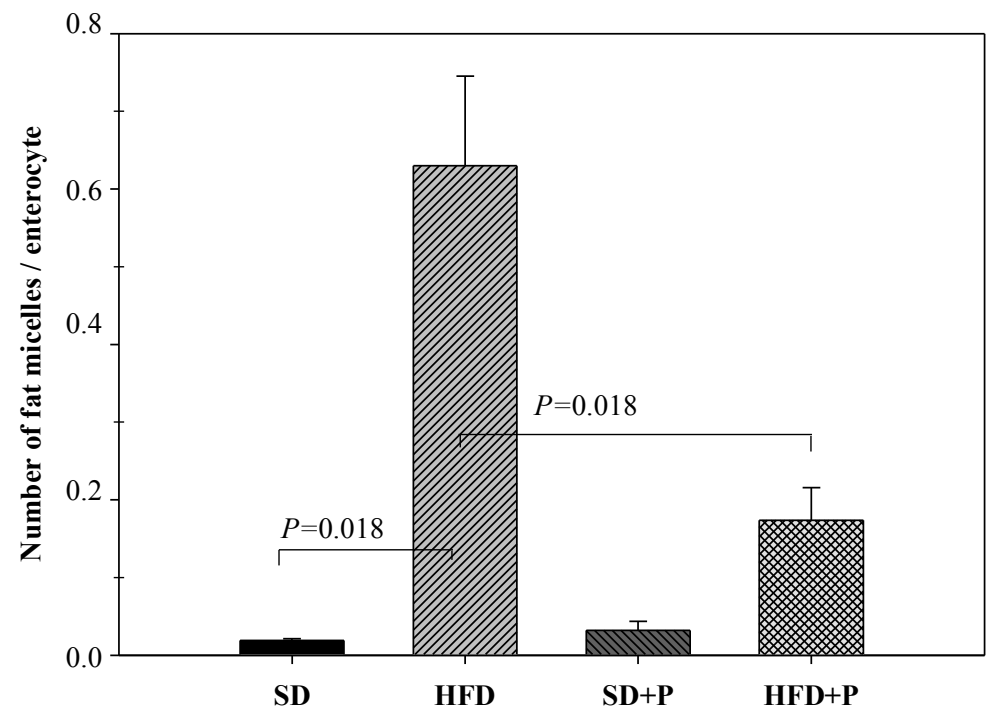


Figure 5. Number of fat micelles per enterocyte in mice fed a standard diet or a high-fat diet, supplemented or not with B. pseudocatenulatum CECT7765. SD: standard diet group (control) $(\mathrm{n}=6)$; SD+P: standard diet group receiving a daily dose of $5.0 \times 10^{8} \mathrm{CFU} /$ mouse of $B$. pseudocatenulatum CECT7765 by gavage for seven weeks ( $\mathrm{n}=6$ ); HFD: high-fat diet group (n=6); HFD+P: high-fat diet group receiving a daily dose of $5.0 \times 10^{8} \mathrm{CFU} /$ mouse of $B$. pseudocatenulatum CECT7765 by gavage for seven weeks $(\mathrm{n}=6)$. Data are expressed as means $\pm \mathrm{SD}$ and statistically significant differences are established at $P<0.05$.

\section{Macrophage functionality}

The results of cytokine production by LPS-stimulated peritoneal macrophages of SD and HFD-fed mice with and without $B$. pseudocatenulatum CECT7765 supplementation are shown in Figure 6-A. Cytokine TNF- $\alpha$ production by peritoneal macrophages stimulated with LPS was lower $(P=0.021)$ in HFD-fed mice than in SD-fed mice (Figure 6-A). However, B. pseudocatenulatum CECT7765 administration significantly increased the ability of LPS-stimulated macrophages to produce TNF- $\alpha$ in HFD $(P=0.021)$ while did not exerted a significant effect in SD-fed mice 
(Figure 6-A). The HFD did not exert a significant effect on the ability of LPSstimulated macrophages to produce the anti-inflammatory cytokine IL-10 (Figure 6-A). B. pseudocatenulatum CECT7765 administration induced a significant increase in IL-10 production by stimulated macrophages in SD-fed mice $(P=0.019)$ but not in those fed a HFD (Figure 6-A).

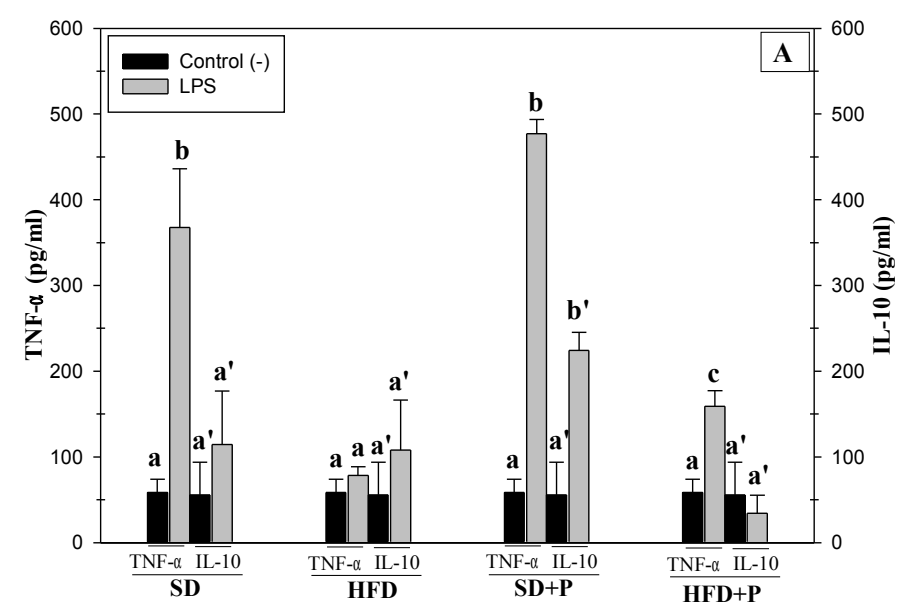

Figure 6-A
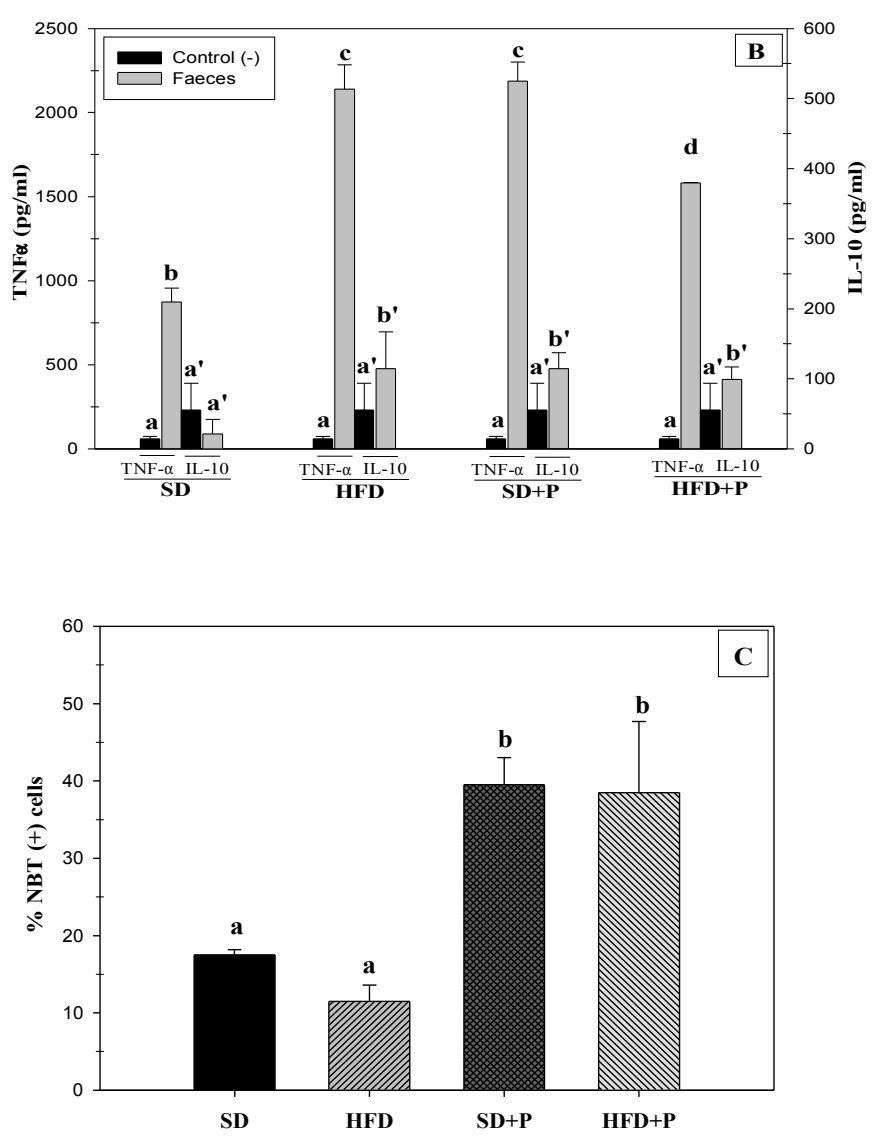
Figure 6. Influence of different stimuli on cytokine production and phagocytosis function in peritoneal macrophages of mice fed standard diet or high-fat diet supplemented or not with $B$. pseudocatenulatum CECT7765. SD: standard diet group (control) $(\mathrm{n}=6)$; SD+P: standard diet group receiving a daily dose of $5.0 \times 10^{8} \mathrm{CFU} /$ mouse of $B$. pseudocatenulatum CECT7765 by gavage for seven weeks $(\mathrm{n}=6)$; HFD: high-fat diet group $(\mathrm{n}=6)$; HFD+P: high-fat diet group receiving a daily dose of 5.0x $10^{8} \mathrm{CFU} /$ mouse of Bifidobacterium CECT7765 by gavage for seven weeks $(\mathrm{n}=6)$. In the cytokine production study, peritoneal macrophages from different mouse groups were stimulated with purified lipopolysaccharide (LPS) from Salmonella enterica serotype Typhimurium (Figure 6-A) and macrophages from control mice were stimulated with faecal samples from different mouse groups (Figure 6-B). Non-stimulated peritoneal macrophages were evaluated as controls of basal cytokine levels. In the phagocytosis study (Figure 6-C), evidence of oxygen-radical production by macrophages was determined by the NBT test after in vitro interaction with a bacterial extract. Data are expressed as mean \pm SD of duplicate measurements determined in two independent experiments. Statistically significant differences were established at $P<0.05$. Means in the bars with different letters were significantly different between mouse groups (a-c for SD vs. HFD and vs. SD+B, a'-d' for HFD vs. HFD+B).

The oxidative burst in peritoneal macrophages after $B$. pseudocatenulatum CECT7765 intake was also studied to analyse effects on phagocytosis function (Figure 6-C), with results indicating this function was boosted in macrophages of both $\mathrm{SD}(P=0.01)$ and HFD-fed mice $(P=0.001)$ (Figure 6-C).

\section{Dendritic cell functionality}

In obese mice, B. pseudocatenulatum CECT 7765 administration increased LPS-stimulated TNF- $\alpha$ production in DCs $(P=0.021)$, which was 
reduced by the HFD $(P=0.021)$ (Figure 7-A). In HFD-fed mice, production of IL-10 by LPS-stimulated DCs was significantly increased $(P=0.01)$, while this effect was partially reversed by the administration of B. pseudocatenulatum CECT7765 ( $P=0.034)$ (Figure 7A). In SD-fed mice, the administration of $B$. pseudocatenulatum CECT7765 also reduced $(P=0.02)$ the ability of LPSstimulated DCs to produced IL-10. The influence of HFD-induced obesity and oral administration of $B$. pseudocatenulatum CECT7765 on the ability of matured DCs to prime a T-cell proliferative response are shown in Figure 7-C.

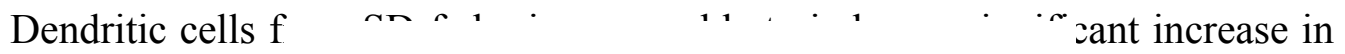

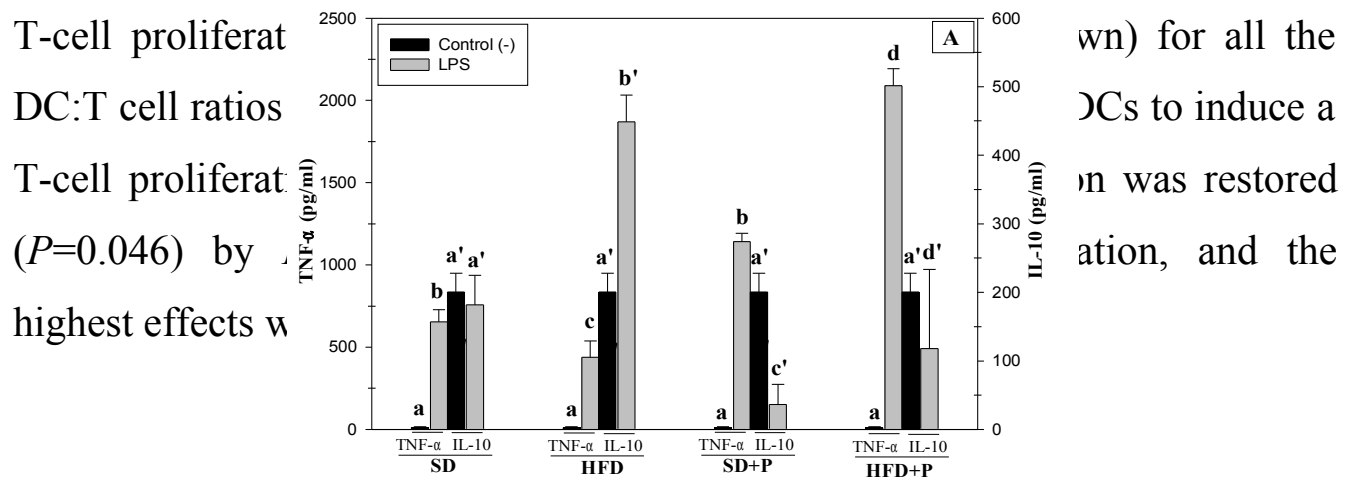
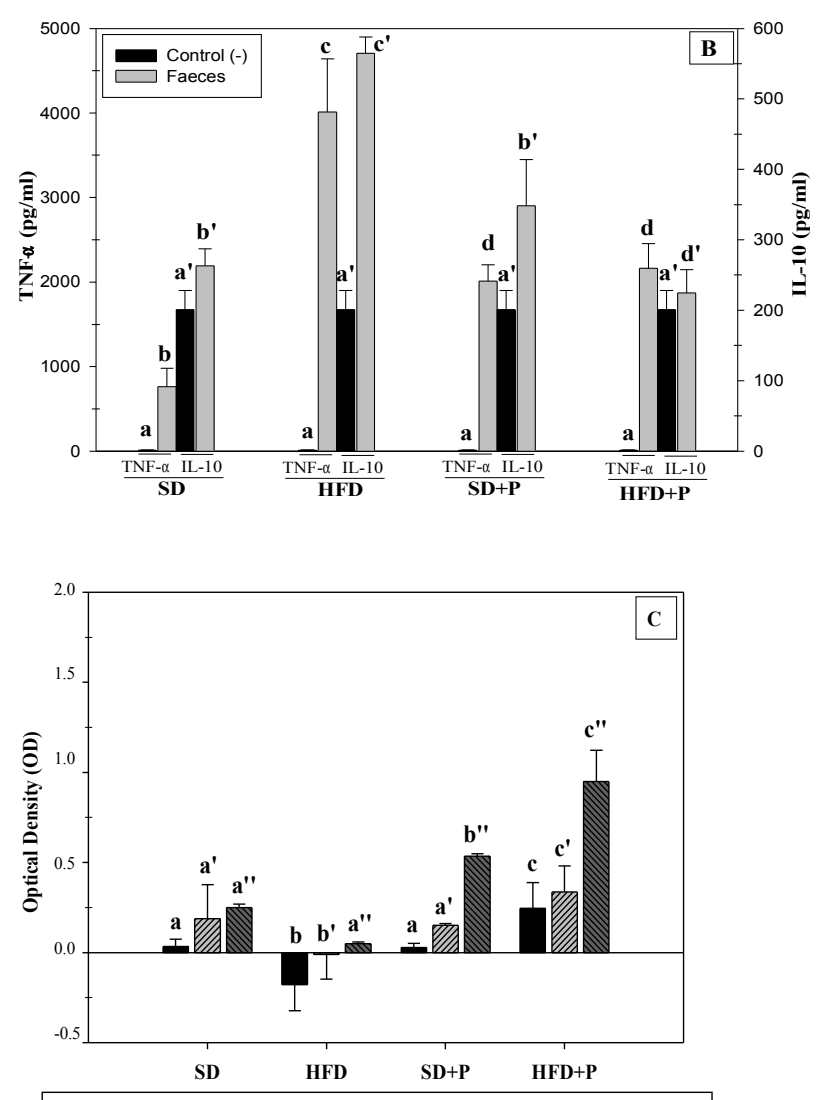

TL / DC ratio: 1/1 שm TLI / DC ratio: 1/2 TL / DC ratio: 1/4 


\section{Figure $7(A, B, C)$}

Figure 7. Influence of different stimuli on cytokine production and activation of Tlymphocyte proliferation by dendritic cells (DCs) generated from mice fed standard diet or high-fat diet, supplemented or not with B. pseudocatenulatum CECT7765. SD: standard diet group (control) $(\mathrm{n}=6)$; $\mathrm{SD}+\mathrm{P}$ : standard diet group receiving a daily dose of $5.0 \times 10^{8}$ $\mathrm{CFU} /$ mouse of $B$. pseudocatenulatum CECT7765 by gavage for seven weeks (n=6); HFD: high-fat diet group $(\mathrm{n}=6)$; HFD+P: high-fat diet group receiving a daily dose of $5.0 \times 10^{8}$ $\mathrm{CFU} /$ mouse of $B$. pseudocatenulatum CECT 7765 by gavage for seven weeks $(\mathrm{n}=6)$. In the cytokine production study, DCs from different mouse groups were stimulated with purified lipopolysaccharide (LPS) from Salmonella enterica serotype Typhimurium (Figure 1-A) and DCs from control mouse groups were stimulated with faecal samples from different mouse groups (Figure 7-B). Non-stimulated DCs were evaluated as controls of basal cytokine levels. In the lymphocyte proliferation study (Figure 7-C), matured DCs were used for priming a Tcell proliferative response at the following $\mathrm{LT} / \mathrm{CD}$ ratios: 1:1, 1:2, 1:4. Lymphocyte proliferation was measured with the cell proliferation ELISA BrdU-colorimetric assay. Data are expressed as means $\pm \mathrm{SD}$ of duplicate measures determined in two independent experiments. Statistically significant differences were established at $P<0.05$. 


\section{Microbiota composition and inflammatory properties}

The composition of the faecal microbiota in SD and HFD-fed mice is shown in Table 4. The HFD led to reductions in numbers of Lactobacillus $(P=0.025), C$. coccoides $(P=0.013)$ and $C$. leptum $(P=0.004)$ groups and Bifidobacterium $(P=0.004)$, and to increases in Enterobacteriaceae $(P=0.025)$. In HFD-fed mice, B. pseudocatenulatum CECT7765 administration increased the numbers of total Bifidobacterium spp. $(P=0.011)$ and reduced those of Enterobacteriaceae $(P=0.007)$, while in SD-fed mice only total numbers of Bifidobacterium spp. $(P=0.05)$ increased.

To evaluate whether these changes in the microbiota composition could modify the inflammatory signals coming from the gut in the different mice groups, assessment was made of faecal samples ability to induce cytokine production by immunocompetent cells in vitro (Figures 6-B and Figures 7-B). Faecal samples from HFD-fed mice induced higher TNF- $\alpha$ production $(P=0.021)$ than those from SD-fed mice by macrophages (Figure 6-B) and DCs from control mice $(P=0.021)$ (Figure 7-B), indicating that the HFD induced an increase in the pro-inflammatory signals coming from the intestine. Meanwhile, B. pseudocatenulatum CECT7765 administration significantly reduced the production of this pro-inflammatory cytokine by studied immune cells $(P=0.043$ in macrophage, $P=0.021$ in DCs), demonstrating its ability to reduce the inflammatory properties of the gut content (Figures 6-B and 7-B). Faecal samples of HFD-fed mice also triggered greater production $(P=0.05)$ of the anti-inflammatory cytokine IL-10 than those from SD-fed mice, which 
could be due to the activation of regulatory mechanisms to counteract an inflammatory response, while $B$. pseudocatenulatum CECT7765 administration reduced $(P=0.02)$ this effect only in DCs (Figures 6-B and 7B). For mice fed SD supplemented with B. pseudocatenulatum CECT7765, faecal samples significantly increased $(P=0.031)$ the synthesis of IL-10 in comparison with control mice in macrophages and a similar trend was detected in DCs.

\section{DISCUSSION}

This study supports the hypothesis that intervention in the gut ecosystem by administration of specific bacterial strains, such as $B$. pseudocatenulatum CECT7765, could ameliorate both metabolic and immunological dysfunctions underlying obesity.

The oral administration of B. pseudocatenulatum CECT7765 to HFD-fed mice induced a decrease in adipocyte size, which could help to curb obesity developing. The largest adipocytes are those that produce the growth factors inducing adipogenesis and maturation of pre-adipocytes into adipocytes, and a 
higher proportion of pro-inflammatory mediators contributing to obesity development ${ }^{24}$. Both HFD-induced liver steatosis and obesity have previously been reported ${ }^{25}$, predisposing hepatocytes to oxidative stress and activating inflammatory pathways ${ }^{26}$. B. pseudocatenulatum CECT7765 administration was also able to reduce fat accumulation in hepatocytes. Moreover, this strain significantly reduced the fat micelles inside enterocytes, which is a potential mechanism whereby adipocyte hypertrophy and liver steatosis could be reduced.

Higher serum leptin concentrations were observed in HFD than in SDfed mice. Under certain physiological conditions, leptin, a hormone produced predominantly in adipocytes, reduces food intake, increases energy expenditure and inhibits lipogenesis. ${ }^{27-29}$ However, obesity often manifests with leptin resistance-associated hyperleptinemia, leading to increased hunger and reduced energy expenditure. ${ }^{30} \quad$ B. pseudocatenulatum CECT7765 $^{2}$ administration decreased leptin levels in obese mice while it increased them in non-obese mice. Reduced leptin levels in obese mice might be beneficial and indicate improved leptin function, which could contribute to the regulation of body-fat distribution and prevention of excessive triglyceride accumulation in peripheral tissues. ${ }^{31}$ In the obesity model, it also is likely that the greater proportion of smaller adipocytes induced by B. pseudocatenulatum CECT7765 administration could be responsible for reducing plasma leptin concentrations ${ }^{32}$ since leptin expression and release may partially depend on adipocyte size. ${ }^{33}$ By contrast, in non-obese mice the increased leptin levels induced by $B$. pseudocatenulatum CECT7765 are expected to be beneficial for body weight 
maintenance due to its anorexigenic role. ${ }^{27-29}$ In this case, the increased leptin levels detected after the administration of the bifidobacterial strain could be related to a slight increase in epididymal adipose tissue weight, since it has been reported that the serum level of leptin correlates with adipose tissue weight or adipocyte size in rodents. ${ }^{33}$ However, we can only speculate about this idea because the differences were not statistically significant and the exact mechanism by which the bifidobacterial strain can modulate leptin levels remains to be determined. B. pseudocatenulatum CECT7765 supplementation also reduced the HFD-induced increase in serum levels of cholesterol, triglycerides, insulin and glucose. Specific probiotic strains have been shown to ameliorate obesity-related metabolic alterations, such as insulin resistance ${ }^{25}$, ${ }^{31,34}$ and increased cholesterol ${ }^{35-37}$, as well as triglyceride levels in rodents and also humans in some cases ${ }^{38-39}$; however, reported effects seem to be strain dependent ${ }^{5} 4022$ The most likely mechanism by which some Lactobacillus and Bifidobacterium strains reduce serum cholesterol is by deconjugation of bile acids. This could lead to a reduction in serum cholesterol either by increasing its utilization in de novo synthesis of bile acids or by reducing cholesterol solubility and thereby their intestinal absorption and uptake by the low-density lipoprotein receptor pathway in the liver. ${ }^{41}$ However, the observed effects could also be due to inhibition of hepatic cholesterol synthesis and/or redistribution of cholesterol from plasma to the liver through the action of short-chain fatty acids, the end products of carbohydrate fermentation by the microbiota in the gut. ${ }^{42}$ The effects of reduced triglyceride levels could also be due to the liporegulatory effects of leptin. Direct peripheral actions by leptin 
have been implicated in depleting fat content through increased fatty acid oxidation as well as suppressed lipogenesis in peripheral tissues. ${ }^{43}$

This study is the first to demonstrate that the bifidobacterial strain administration improves the immunological dysfunction associated with obesity in mice. Oral administration of B. pseudocatenulatum CECT7765 increased the oxidative burst not only in the control but also in HFD fed mice, indicating an improvement in this defence mechanism against pathogens in the context of obesity. It is known that macrophage function is impaired in obese mice, with reduced phagocytic capacity and oxidative burst, which has been linked to increased susceptibility to infections in obese subjects. ${ }^{44}$ Our study also demonstrated that cytokine production (TNF- $\alpha)$ by peritoneal macrophages and DCs in response to a pathogenic bacterial stimulus (LPS) is boosted by B. pseudocatenulatum CECT7765, which could improve the ability of immunocompetent cells to produce appropriate inflammatory responses in face to infection. This study also confirms that a HFD impairs DC function and that B. pseudocatenulatum CECT7765 could restore it, improving the ability of DCs to present antigens and stimulate T-lymphocyte proliferation. Macia et al. ${ }^{45}$ also demonstrated a functional deficiency of DCs in $o b / o b$ mice, suggesting that this damage could be generalized to the more frequent forms of obesity. This DC dysfunction could lead to impaired antigen-specific immune responses of adaptive immunity, which could be involved in the high incidence of infection reported in obese patients and in hypo-responsiveness to vaccination. $^{2}$ 
The present study also reports differences in the gut microbiota between non-obese and obese HFD-fed mice, which are in agreement with previous studies ${ }^{46-47}$, and may partly be related to diet ${ }^{48}$. Our results show that obese mice harboured a significant reduction in gene copy numbers of Lactobacillus and Clostridium groups and, particularly, Bifidobacterium genus, which is partially in agreement with previous studies. ${ }^{9,46-47}$ In contrast, other authors found reductions in Bacteroidetes abundance and increases in Firmicutes in $o b / o b$ mice ${ }^{6,48}$. B. pseudocatenulatum CECT7765 administration increased total Bifidobacterium and reduced Enterobacteriaceae numbers. These changes in the microbiota composition could contribute to reducing the inflammatory signals coming from the gut, which could affect other peripheral tissues involved in obesity.

Taking the results as a whole, this pre-clinical study supports the notion that dietary strategies targeting the gut ecosystem with specific bacterial strains could be effective to control metabolic disorders and the associated immunological dysfunction, although definitive evidence should be provided by human trials.

\section{Acknowledgements}

This work was supported by grants AGL2008-01440/ALI and Consolider FunC-Food CSD2007-00063 from the Spanish Ministry of Science and Innovation (MICINN, Spain) The scholarships of A. Santacruz from CONACYT 
(México) and P. Gauffin Cano from CONICET (Argentina) and the contract of F. Trejo from MICIIN (Spain) are fully acknowledged.

\section{REFERENCES}

1 Haslam DW, James WP Obesity. Lancet 2005;366(9492):1197-1209.

2 Wolowczuk I, Verwaerde C, Viltart O, Delanoye A, Delacre M, Pot B et al. Feeding our immune system: impact on metabolism. Clin Dev Immunol 2008;2008:639803.

3 Sanz Y, Santacruz A, Gauffin P Gut microbiota in obesity and metabolic disorders. Proc Nutr Soc 2010;69(3):434-441.

4 Duncan SH, Lobley GE, Holtrop G, Ince J, Johnstone AM, Louis P et al. Human colonic microbiota associated with diet, obesity and weight loss. Int J Obes (Lond) 2008;32(11):1720-1724.

5 Ley RE, Turnbaugh PJ, Klein S, Gordon JI Microbial ecology: human gut microbes associated with obesity. Nature 2006;444(7122):1022-1023.

6 Ley RE, Backhed F, Turnbaugh P, Lozupone CA, Knight RD, Gordon JI Obesity alters gut microbial ecology. Proc Natl Acad Sci U $S$ A 2005;102(31):11070-11075.

7 Nadal I, Santacruz A, Marcos A, Warnberg J, Garagorri M, Moreno LA et al. Shifts in clostridia, bacteroides and immunoglobulin-coating fecal bacteria associated with weight loss in obese adolescents. Int $J$ Obes (Lond) 2009;33(7):758-767.

8 Santacruz A, Marcos A, Warnberg J, Marti A, Martin-Matillas M, Campoy $\mathrm{C}$ et al. Interplay between weight loss and gut microbiota composition in overweight adolescents. Obesity (Silver Spring) 2009;17(10):19061915.

9 Waldram A, Holmes E, Wang Y, Rantalainen M, Wilson ID, Tuohy KM et al. Top-down systems biology modeling of host metabotype- 
microbiome associations in obese rodents. $J$ Proteome Res 2009;8(5):2361-2375.

10 Cani PD, Delzenne NM Interplay between obesity and associated metabolic disorders: new insights into the gut microbiota. Curr Opin Pharmacol 2009;9(6):737-743.

11 Tuohy KM, Probert HM, Smejkal CW, Gibson GR Using probiotics and prebiotics to improve gut health. Drug Discov Today 2003;8(15):692700.

12 Satokari RM, Vaughan EE, Akkermans AD, Saarela M, de Vos WM Bifidobacterial diversity in human feces detected by genus-specific PCR and denaturing gradient gel electrophoresis. Appl Environ Microbiol 2001;67(2):504-513.

13 Favier CF, Vaughan EE, De Vos WM, Akkermans AD Molecular monitoring of succession of bacterial communities in human neonates. Appl Environ Microbiol 2002;68(1):219-226.

14 Satokari RM VE, Akkermans AD, Saarela M, de Vos WM Bifidobacterial Diversity in Human Feces Detected by Genus-Specific PCR and Denaturing Gradient Gel Electrophoresis Applied and Environmental Microbiology 2001;67:504-513.

15 Cariou B, van Harmelen K, Duran-Sandoval D, van Dijk TH, Grefhorst A, Abdelkarim $\mathrm{M}$ et al. The farnesoid $\mathrm{X}$ receptor modulates adiposity and peripheral insulin sensitivity in mice. $J$ Biol Chem 2006;281(16):11039-11049.

16 Vieira JM, Seabra SH, Vallim DC, Americo MA, Fracallanza SE, Vommaro $\mathrm{RC}$ et al. Bacteroides fragilis induce necrosis on mice peritoneal macrophages: In vitro and in vivo assays. Biochem Biophys Res Commun 2009;387(4):627-632.

17 Ciccocioppo R, Rossi M, Pesce I, Ricci G, Millimaggi D, Maurano F et al. Effects of gliadin stimulation on bone marrow-derived dendritic cells from HLA-DQ8 transgenic MICE. Dig Liver Dis 2008;40(12):927-935.

18 Matsuki T, Watanabe K, Fujimoto J, et al. Development of 16S rRNAgene-targeted group-specific primers for the detection and identification of predominant bacteria in human feces. Appl Environ Microbiol 2002; 68: 5445-51.

19 Matsuki T, Watanabe K, Fujimoto J, Takada T, Tanaka R. Use of $16 \mathrm{~S}$ rRNA gene-targeted group-specific primers for real-time PCR analysis of predominant bacteria in human feces. Appl Environ Microbiol 2004; 70:7220-8. 
20 Malinen E, Rinttilä T, Kajander K, et al. Analysis of the fecal microbiota of irritable bowel syndrome patients and healthy controls with real-time PCR. Am J Gastroenterol 2005; 100(2):373-82.

21 Walter J, Hertel C, Tannock GW, Lis CM, Munro K, Hammes WP. Detection of Lactobacillus, Pediococcus, Leuconostoc, and Weissella species in human feces by using group-specific PCR primers and denaturing gradient gel electrophoresis. Appl Environ Microbiol 2001; 67(6):2578-85.

22 Heilig HGHJ, Zoetendal EG, Vaughan EE, Marteau P, Akkermans ADL, de Vos WM. Molecular diversity of Lactobacillus spp. and other lactic acid bacteria in the human intestine as determined by specific amplification of 16S ribosomal DNA. Appl Environ Microbiol 2002; 68:114-123.

23 Santacruz A, Collado MC, Garcia-Valdes L, Segura MT, Martin-Lagos JA, Anjos T et al. Gut microbiota composition is associated with body weight, weight gain and biochemical parameters in pregnant women. Br J Nutr 2010;104(1):83-92.

24 Marques BG, Hausman DB, Martin RJ Association of fat cell size and paracrine growth factors in development of hyperplastic obesity. Am J Physiol 1998;275(6 Pt 2):R1898-1908.

25 Ma X, Hua J, Li Z Probiotics improve high fat diet-induced hepatic steatosis and insulin resistance by increasing hepatic NKT cells. $J$ Hepatol 2008;49(5):821-830.

26 Boden G, She P, Mozzoli M, Cheung P, Gumireddy K, Reddy P et al. Free fatty acids produce insulin resistance and activate the proinflammatory nuclear factor-kappaB pathway in rat liver. Diabetes 2005;54(12):34583465 .

27 Ahima RS, Prabakaran D, Mantzoros C, Qu D, Lowell B, Maratos-Flier E et al. Role of leptin in the neuroendocrine response to fasting. Nature 1996;382(6588):250-252.

28 Zhang Y, Proenca R, Maffei M, Barone M, Leopold L, Friedman JM Positional cloning of the mouse obese gene and its human homologue. Nature 1994;372(6505):425-432.

29 Schwartz MW, Woods SC, Porte D, Jr., Seeley RJ, Baskin DG Central nervous system control of food intake. Nature 2000;404(6778):661671. 
30 El-Haschimi K, Pierroz DD, Hileman SM, Bjorbaek C, Flier JS Two defects contribute to hypothalamic leptin resistance in mice with dietinduced obesity. J Clin Invest 2000;105(12):1827-1832.

31 Jiang L, Wang Q, Yu Y, Zhao F, Huang P, Zeng R et al. Leptin contributes to the adaptive responses of mice to high-fat diet intake through suppressing the lipogenic pathway. PLoS One 2009;4(9):e6884.

32 Sato M, Uzu K, Yoshida T, Hamad EM, Kawakami H, Matsuyama H et al. Effects of milk fermented by Lactobacillus gasseri SBT2055 on adipocyte size in rats. Br J Nutr 2008;99(5):1013-1017.

33 Guo KY, Halo P, Leibel RL, Zhang Y Effects of obesity on the relationship of leptin mRNA expression and adipocyte size in anatomically distinct fat depots in mice. Am J Physiol Regul Integr Comp Physiol 2004;287(1):R112-119.

34 Loguercio C, De Simone T, Federico A, Terracciano F, Tuccillo C, Di Chicco $\mathrm{M}$ et al. Gut-liver axis: a new point of attack to treat chronic liver damage? Am J Gastroenterol 2002;97(8):2144-2146.

35 Park YH, Kim JG, Shin YW, Kim SH, Whang KY Effect of dietary inclusion of Lactobacillus acidophilus ATCC 43121 on cholesterol metabolism in rats. J Microbiol Biotechnol 2007;17(4):655-662.

36 Usman, Hosono A Effect of administration of Lactobacillus gasseri on serum lipids and fecal steroids in hypercholesterolemic rats. J Dairy Sci 2000;83(8):1705-1711.

37 Paik HD, Park JS, Park E Effects of Bacillus polyfermenticus SCD on lipid and antioxidant metabolisms in rats fed a high-fat and highcholesterol diet. Biol Pharm Bull 2005;28(7):1270-1274.

38 Kiessling G, Schneider J, Jahreis G Long-term consumption of fermented dairy products over 6 months increases HDL cholesterol. Eur J Clin Nutr 2002;56(9):843-849.

39 Kekkonen RA, Sysi-Aho M, Seppanen-Laakso T, Julkunen I, Vapaatalo $\mathrm{H}$, Oresic $\mathrm{M}$ et al. Effect of probiotic Lactobacillus rhamnosus GG intervention on global serum lipidomic profiles in healthy adults. World J Gastroenterol 2008;14(20):3188-3194.

40 Yin YN, Yu QF, Fu N, Liu XW, Lu FG Effects of four Bifidobacteria on obesity in high-fat diet induced rats. World $J$ Gastroenterol 2010;16(27):3394-3401.

41 Begley M, Hill C, Gahan CG Bile salt hydrolase activity in probiotics. Appl Environ Microbiol 2006;72(3):1729-1738. 
42 Backhed F, Manchester JK, Semenkovich CF, Gordon JI Mechanisms underlying the resistance to diet-induced obesity in germ-free mice. Proc Natl Acad Sci U S A 2007;104(3):979-984.

43 Lee Y, Wang MY, Kakuma T, Wang ZW, Babcock E, McCorkle K et al. Liporegulation in diet-induced obesity. The antisteatotic role of hyperleptinemia. J Biol Chem 2001;276(8):5629-5635.

44 Zhou Q, Leeman SE, Amar S Signaling mechanisms involved in altered function of macrophages from diet-induced obese mice affect immune responses. Proc Natl Acad Sci U S A 2009;106(26):10740-10745.

45 Macia L, Delacre M, Abboud G, Ouk TS, Delanoye A, Verwaerde C et al. Impairment of dendritic cell functionality and steady-state number in obese mice. J Immunol 2006;177(9):5997-6006.

46 Cani PD, Neyrinck AM, Fava F, Knauf C, Burcelin RG, Tuohy KM et al. Selective increases of bifidobacteria in gut microflora improve high-fatdiet-induced diabetes in mice through a mechanism associated with endotoxaemia. Diabetologia 2007;50(11):2374-2383.

47 Cani PD, Amar J, Iglesias MA, Poggi M, Knauf C, Bastelica D et al. Metabolic endotoxemia initiates obesity and insulin resistance. Diabetes 2007;56(7):1761-1772.

48 Murphy EF, Cotter PD, Healy S, Marques TM, O'Sullivan O, Fouhy F et al. Composition and energy harvesting capacity of the gut microbiota: relationship to diet, obesity and time in mouse models. Gut 2010; 59(12): $1635-1642$ 


\section{DISCUSIÓN GENERAL}

En un primer estudio se evaluó la influencia en la microbiota y la relación con la pérdida de peso de un programa multidisciplinario para tratar la obesidad en adolescentes, basado en una dieta con restricción calórica y aumento de la actividad física. En este estudio se observó que la reducción del peso corporal estaba asociada a un aumento de las concentraciones o proporciones relativas de los grupos Bacteroides o Bacteroides-Prevotella y Lactobacillus, y a reducciones del grupo E. rectale-C. coccoides en la microbiota intestinal de aquellos adolescentes que experimentaron pérdidas de peso significativas, pero no así en los que no presentaron pérdida significativa de peso. En este estudio, la aplicación de técnicas distintas (qPCR y FISH) para analizar la microbiota intestinal dio lugar a similares resultados, lo que aportó mayor consistencia a las asociaciones establecidas entre la microbiota y la pérdida de peso.

Los grupos bacterianos más susceptibles al cambio de dieta fueron Bacteroides fragilis y Lactobacillus, que mostraron correlaciones negativas con la ingesta de carbohidratos y los ácidos grasos poli-insaturados (PUFA) ingeridos, sugiriendo su posible manipulación a través de la misma. Esto tiene relación con lo reportado en trabajos previos en donde se obtuvo que el género bacteroides presentó una alta habilidad para utilizar los carbohidratos complejos (Stappenbeck, 2002). En otros estudios también se ha establecido una estrecha relación entre el grupo de Lactobacillus y la absorción de PUFA in situ, los cuales han demostrado influir positivamente en la adhesión de los 
Lactobacillus en la mucosa del jejuno en cerdos gnotobióticos. La ingesta de los PUFA podría ayudar a mantener los niveles de este grupo bacteriano dentro del tracto digestivo (Kankaanpää, 2004; Bomba, 2003). Sin embargo son escasos los estudios que comprueban el impacto de las dietas bajas en grasas y carbohidratos con las concentraciones de Lactobacillus spp.

Con respeto a las especies del género Bifidobacterium, los recuentos de B. longum y $B$. adolescentis se redujeron en el total de la población de adolescentes obesos tras la intervención. Estudios fisiológicos y genómicos indican que estas especies participan activamente en la utilización de polisacáridos complejos en el colon (Belenguer, 2006), cuya ingesta se redujo en la intervención y podría ser consecuencia de su disminución. De acuerdo con nuestro resultados, Duncan et al. (2007) también observaron una reducción en los recuentos de Bifidobacterium spp. al disminuir la ingesta de carbohidratos en un grupo de adultos obesos.

En cuanto al grupo de Lactobacillus se detectaron aumentos en la microbiota de toda la población de adolescentes después del tratamiento y este aumento presentó una correlación con la pérdida de peso y el $z$-score del IMC, asociándose por tanto a la regulación del peso corporal de modo positivo. Sin embargo, la función de cepas del genero Lactobacillus en la obesidad sigue estando en debate. En estudios de intervención con cepas consideradas probióticas en adultos no se han observado efectos adversos sino incluso moderadamente positivos (Kadooka, 2010) y en niños tan sólo se ha descrito que el crecimiento y desarrollo no están afectados o que se favorece 
alcanzando valores normales, en situaciones especiales como grupos de población carencias nutricionales o mayor susceptibilidad a infecciones (Weizman, 2006; Dupont, 2010).

El incremento en el grupo de Bacteroides asociado a la pérdida de peso en adolescentes podría estar implicado en la mejora de parámetros metabólicos, por ejemplo contribuyendo a la generación de propionato, que podría ser un inhibidor de la síntesis de lípidos a partir de acetato (Pouteau, 2003; Walker, 2005). En un estudio anterior, Ley et al (2006) también indicaron que la pérdida de peso en adultos sometidos a una dieta con restricción en hidratos de carbono o en lípidos estaba asociada a reducciones en la proporción del filo Bacteroidetes, lo cual concuerda con nuestros resultados. Sin embargo, esta asociación positiva no ha sido confirmada por otros estudios como el de Duncan et al. (2008) que no encontró relación entre el género Bacteroides y la obesidad, al comparar un grupo de individuos obesos y uno control sometidos a una dieta baja en calorías.

En adolescentes con sobrepeso también se observó que la disminución de los grupos E. rectale - C.coccoides y Clostridium histolyticum se correlacionaba con la pérdida de peso en toda la población de adolescentes y en el grupo que experimentó una pérdida significativa de peso. En estudios previos se indicó que cambios en las proporciones relativas de los filos Firmicutes (al que pertenecen los clostridios y Bacteroidetes estaban asociados a la obesidad y pérdida de peso en adultos, de forma similar a nuestro estudio. Estos cambios eran evidentes cuando la pérdida de peso era por lo menos de 
ente un 2 y un $6 \%$ del peso corporal, sin encontrar una relación con el tipo de dieta (Ley, 2006). En este contexto, se ha observado que el cluster XIV al cual pertenecen E. rectale- C. coccoides es uno de los principales implicados en la fermentación colónica y la producción de butirato en la parte distal del colon (Egran, 2001). La reducción de ese grupo bacteriano, consecuencia de la intervención para tratar la obesidad, podría contribuir a reducir la habilidad de la microbiota intestinal para obtener la energía de la dieta por medio de la fermentación, que puede llegar a suponer el 10 o 15\% del aporte de calorías diario. No obstante, la posible función de los ácidos grasos de cadena corta en la obesidad es todavía controvertida y por ejemplo, al butirato se le ha atribuido un efecto positivo por contribuir a la formación de péptidos (péptido similar al glucagón-1) que inducen sensación de saciedad.

Asimismo, el estudio en adolescentes con sobrepeso demostró que la microbiota del individuo puede influir en la eficacia de las intervenciones basadas en cambios en el estilo de vida para tratar la obesidad. En concreto, la microbiota de los adolescentes que experimentaron una pérdida de peso significativa se caracterizó por presentar mayores concentraciones iniciales y finales de los grupos B. fragilis y C. leptum y B. catenulatum y menores de los grupos C. coccoides, Lactobacillus y Bifidobacterium, B. breve y $B$. bifidum, en comparación con los que no experimentaron una pérdida de peso significativa.

En el estudio en adolescentes también se evaluó la relación entre la microbiota y el sistema inmune debido a que la obesidad se asocia con una 
inflamación crónica de bajo grado, cada vez más frecuenta a edades tempranas. Con esta finalidad, se determinaron las inmunoglobulinas IgA, IgG e IgM unidas a bacteria en heces, como un primer indicador de la capacidad de la microbiota intestinal de estimular el sistema inmune de la mucosa. En los adolescentes con sobrepeso se detectó un aumento especialmente de la proporción de IgA asociada a bacterias intestinales, relacionado con las proporciones de $C$. histolyticum y $E$. rectale-C. coccoides, que se redujeron tras la intervención en aquellos individuos que experimentaron mayor reducción de peso. Estos resultados sugieren que algunos componentes de la microbiota, posiblemente implicados en la obesidad o sus metabolitos, influyen en el sistema inmunitario del hospedador. Entre los integrantes del grupo $C$. histolyticum existen especies citotóxicas (De Graaf, 2008), cuyos niveles incrementados podrían contribuir a la activación del sistema inmunitario en sujetos obesos. Por otro lado, la reducción del número de grupos bacterianos productores de butirato, como los miembros del grupo E. rectale-C. coccoides tras la intervención, podría estar relacionado con una reducción del aporte de energía necesario para las células del sistema inmune y, por consiguiente, la reducción de las células productoras de IgA y de la concentración de IgA en la mucosa (Marschan, 2008; Peuranen, 2004)

En cuanto el estudio realizado en mujeres embarazadas, el sobrepeso se asoció a aumentos en las concentraciones de los grupos Staphylococcus, Enterobacteriaceae y E.coli, y reducciones en las de los géneros Bifidobacterium y Bacteroides. El aumento de E. coli y la reducción de Bifidobacterium spp. y Akkermansia muciniphila también se asoció a la 
ganancia excesiva de peso durante el embarazo. Por tanto, la asociación entre los niveles de Bacteroides spp. y el peso corporal se confirmó tanto en adolescentes como en embarazadas, aunque su influencia en la regulación del peso corporal sigue siendo controvertida como se ha indicado anteriormente. En cuanto a las mujeres embarazadas se sugiere una relación positiva del grupo Lactobacillus como posible responsable de la regulación de la ganancia de peso por el hijo.

En el estudio realizado en embarazadas también se correlacionando los parámetros bioquímicos con los cambios de microbiota. El aumentos en la concentración de colesterol sérico se relacionó con aumentos en Staphylococcus spp., y el algunos estudios sugieren que el colesterol puede estimular el crecimiento de algunas especies de estafilococos como $S$. aureus (Shine, 1993). Incrementos en el número de Bacteroides spp., ser correlacionaron con aumentos en el colesterol HDL y reducciones en el colesterol total. Aumentos en el número de Bifidobacterium spp se correlacionaron con aumentos en ácido fólico, que podrían relacionarse con la habilidad de algunas cepas de sintetizar folatos en el intestino (Strozzi, 2008). Por último, los niveles de ferritina and transferrina reducida mostraron relaciones opuestas con las concentraciones de enterobacterias y Bifidobacterium spp. En este contexto, aumento en el índice de saturación de transferrina en el suero, debido a una reducción en transferrina y a un aumento en ferritina, se han asociado con una reducción de la actividad antibacteriana del suero frente a enterobacterias (Jolivet-Gougeon, 2008), aunque la repercusión de este fenómeno en la microbiota intestinal se desconoce. 
A fin de tener evidencias más directas sobre el posible efecto de una bacteria potencialmente probiótica en la obesidad, se seleccionó una cepa del género Bifidobacterium y se administró a un modelo animal de obesidad inducida por la dieta. La administración oral de B. pseudocatenulatum CECT 7765 mejoró las alteraciones bioquímicas e inmunológicas asociadas a la obesidad inducida por una dieta rica en grasa en ratones. La administración de esta cepa redujo la esteatosis hepática y el tamaño de los adipocitos y las concentraciones de glucosa en suero y de lípidos (colesterol y triglicéridos) en suero y en el hígado, la concentración de leptina en suero y mejoró las funciones de células inmunocompetentes (macrófagos y células dendríticas) alteradas por la obesidad.

En previos estudios se ha publicados que ciertas bacterias probióticas pueden reducir los parámetros bioquímicos colesterol, triglicéridos, LDLcolesterol, HDL-colesterol en modelos de animales y en humanos (Kiessling, 2002; Kekkonen, 2008). El mecanismo por el cual algunas cepas de Lactobacillus y Bifidobacterium pueden disminuir el colesterol podría ser por su capacidad para desconjugar las sales biliares (Begley, 2006). No obstante, los efectos observados también podrían deberse a la inhibición de la síntesis hepática de colesterol y a la redistribución de colesterol del plasma al hígado a través de la acción de los ácidos cortos de cadena corta, que son los productos finales de la fermentación de los carbohidratos por la microbiota intestinal. La cepa evaluada también redujo la absorción de lípidos de la dieta por los enterocitos, lo que podría contribuir a la reducción de lípidos observada en 
suero así como a la reducción en la reducción de la esteatosis hepática y el tamaño de los adipocitos.

Pese a que en condiciones fisiológicas la síntesis de leptina reduce la ingesta de alimentos, incrementa el gasto energético e inhibe la lipogénesis (Ahima, 1996; Schwartz, 1994; Zhang, 2000) la obesidad a menudo se manifiesta con hiperleptinemia y resistencia a la leptina (El-Haschimi, 2000). En el modelo animal de obesidad, la cepa administrada también disminuyó los niveles de leptina en los ratones obesos lo que puede indicar una mejora de su función, relacionada por ejemplo con la reducción del tamaño de los adipocitos.

El estudio en el modelo animal de obesidad demuestra por primera vez que la administración oral de una bacteria potencialmente probiótica, como $B$. pseudocatenulatum CECT7765, mejora la disfunción inmunológica asociada a la obesidad en ratones. La administración de esta cepa mejoró la función de macrófagos en la fagocitosis, tanto en animales obesos como controles, lo que refleja una mejora en el mecanismo de defensa frente a patógenos. En sujetos obesos se ha demostrado que los macrófagos presentan una disminución en su capacidad de fagocitosis y respuesta oxidativa, lo cual aumenta su susceptibilidad a infecciones (Zhou, 2009). Además, la administración de esta cepa incrementó la capacidad de macrófagos y células dendríticas para producir TNF- $\square$ en respuesta a un estímulo de patógenos como el LPS, lo que sugiere también una posible mejora de la respuesta defensiva frente a infecciones. Este estudio también confirma que una dieta rica en grasa altera la función de las células dendríticas, reduciendo por ejemplo su habilidad para 
presentar antígenos y estimular la proliferación de los linfocitos $\mathrm{T}$ tal como se ha descrito en artículos previos (Wolowczuk, 2008; Macia, 2006). Sin embargo, la cepa administrada también mejora esta función en animales controles y obesos.

La administración de B. pseudocatenulatum CECT7765 al modelo de obesidad también restableció parcialmente las alteraciones de la microbiota intestinal detectadas en animales obesos, aumentando la abundancia del grupo C. coccoides y del género Bifidobacterium y reduciendo la de la familia Enterobaceriaceae. Además, se demostró que estos cambios en la microbiota atenuaban sus propiedades inflamatorias, que se han relacionado con el aumento de peso, la resistencia a la insulina, la endotoxemia metabólica (Cani, 2007). En ratas obesas Zucker $(f a / f a)$ y ratones alimentados con una dieta alta en grasa también se han detectado reducciones en el número de Bifidobacterium spp. con respecto al control (Waldram, 2009; Cani, 2007), coincidiendo con nuestros resultados.

Los estudios realizados en humanos en el marco de esta tesis doctoral presentan algunas limitaciones, como el tamaño relativamente reducido de la población estudiada y la corta duración de las intervenciones, que podrían reducir el grado de significación de las asociaciones detectadas entre la microbiota, el peso corporal, los parámetros bioquímicos y la dieta. No obstante, las asociaciones identificadas y, algunas de ellas, confirmadas por otros autores han aportado información clave para avanzar en el desarrollo de estudios que permitan demostrar de forma directa una relación causal entre 
determinadas bacterias y la obesidad y alteraciones metabólicas relacionadas. En este contexto, la evaluación preclínica del efecto de una cepa del género Bifidobacterium en un modelo de obesidad en esta tesis doctoral, ya ha aportado evidencia directa de su posible aplicación práctica, aunque esta posibilidad deberá ser confirmada finalmente mediante la realización de adecuados estudios en humanos. 


\section{Conclusiones}

1.- La reducción del peso corporal, como consecuencia de una intervención basada en la reducción del aporte calórico de la dieta y el aumento de la actividad física para tratar la obesidad, se asoció a un aumento de las concentraciones o proporciones relativas de los grupos Bacteroides o Bacteroides-Prevotella y Lactobacillus, así como a reducciones del grupo E. rectale-C. coccoides en la microbiota intestinal de aquellos adolescentes que experimentaron pérdidas de peso significativas.

2. La microbiota de los adolescentes que experimentaron una pérdida de peso significativa se caracterizó por presentar mayores concentraciones iniciales y finales de los grupos $B$. fragilis y $C$. leptum y B. catenulatum y menores de los grupos $C$. coccoides, Lactobacillus y Bifidobacterium, B. breve y $B$. bifidum, lo que sugiere que la microbiota del individuo puede influir en la eficacia de las intervenciones basadas en cambios en el estilo de vida para tratar la obesidad.

3. En adolescentes obesos se detectó un aumento de la proporción de IgA asociada a bacterias intestinales, relacionado con las proporciones de $C$. histolyticum y E. rectale - C. coccoides, que se redujeron tras la intervención para tratar la obesidad, lo que sugiere que algunos componentes de la microbiota posiblemente implicados en la obesidad o sus metabolitos influyen en el sistema inmunitario del hospedador. 
4.- El sobrepeso durante el embarazo se asoció a aumentos en las concentraciones de los grupos Staphylococcus, Enterobacteriaceae y E.coli, y reducciones en las de los géneros Bifidobacterium y Bacteroides. El aumento de E. coli y la reducción de Bifidobacterium spp. y Akkermansia muciniphila también se asoció a la ganancia excesiva de peso durante el embarazo.

5. En mujeres embarazadas se detectaron asociaciones entre algunos de los grupos bacterianos de la microbiota intestinal y parámetros bioquímicos que pueden tener influencia en la salud de la madre y el hijo. Aumentos en la concentración de colesterol sérico se relacionaron con aumentos en Staphylococcus spp., aumentos en el colesterol HDL y reducciones en el colesterol total ser relacionaron con aumentos en Bacteroides spp., aumentos en ácido fólico se relacionaron con aumentos en Bifidobacterium spp. y los niveles de ferritina and transferrina reducida mostraron relaciones opuestas con las concentraciones de enterobacterias y Bifidobacterium spp.

6. La administración de Bifidobacterium pseudocatenulatum CECT 7765 a ratones con obesidad inducida por la dieta mejoró las alteraciones bioquímicas e inmunológicas asociadas a la obesidad inducida por una dieta rica en grasa. La administración de esta cepa redujo la esteatosis hepática y el tamaño de los adipocitos y las concentraciones de glucosa en suero y de lípidos (colesterol y triglicéridos) en suero y en el hígado, y mejoró las funciones de células inmunocompetentes (macrófagos y células dendríticas) alteradas por la obesidad. 
7. La administración de Bifidobacterium pseudocatenulatum CECT 7765 a ratones con obesidad inducida por la dieta restableció parcialmente la composición de la microbiota intestinal y redujo sus propiedades inflamatorias, lo que favorecería el control de la inflamación asociado a la obesidad y patologías relacionadas. 


\section{REFERENCIAS}

1. Ahima RS, Prabakaran D, Mantzoros C, et al, 1996, Role of leptin in the neuroendocrine response to fasting, Nature,382(6588):250-252.

2. Amber V, Bloom SR, 2007, Adiposity and the Gut. The role of gut hormones, Current Nutrition \& Food Science, 3:75-90

3. Angelaski E, Armougom F, Million M, et al, 2012, The relationship between gut microbiota and weight gain in human, Future Microbiol, 7 (1): 91-99

4. Aranceta J, Pérez-Rodrigo C, Serra-Majem L, et al, 2007, Prevention of overweight and obesity: a Spanish approach, Public Health Nutr, 10(10A):1187-1193

5. August GP, Caprio S, Fennoy I, et al, 2008, Endocrine Society, Prevention and treatment of pediatric obesity: an endocrine society clinical practice guideline based on expert opinion, Clin Endocrinol Metab, 93(12):4576-99.

6. Bäckhed F, Ding H, Wang T, et al, 2004, The gut microbiota as an environmental factor that regulates fat storage, Proc Natl Acad Sci, $\underline{101(44): 15718-15723}$

7. Barker, DJP, Osmond C, Golding J, et al, 1989, Grown in utero, blood pressure in childhood and adult life, and mortality from cardiovascular disease, $B M J$, 564-567 
8. Basseri R, Basseri B, Pimentel M, et al, 2012, Intestinal Methane production in obese individual is associated with a higher Body Mass Index, Gastr Hep, 8 (1): 22-28

9. Belenguer A, Duncan SH, Calder AG, 2006, Two routes of metabolic cross-feeding between Bifidobacterium adolescentis and butyrateproducing anaerobes from the human gut, Applied and Enviromental Microbiology,72(5):3593-3599

10. Bernardo CO, Vasconcelos FAG, 2012, Association of parents 'nutritional status, and sociodemographic and dietary factors with overweight/obesity in schoolchildren 7 to 14 years old, Cad. Saúde Pública, 28(2): 291-304

11. Bik EM, 2009, Composition and function of the human-associated microbiota, Nutr Rev, 67 Suppl 2:S164-S171

12. Blancas-Flores G, Almanza-Pérez JC, López-Roa RI, et al, 2009, La obesidad como un proceso inflamatorio, Bol Med Hosp Infant Mex, 6:89-96

13. Booij YS, Leerdam van F, Stolte IG, et al, 2008, Knowledge of parents about overweight and healthy food for children Dutch, Tijdschrift voor Jeugdgezondheidszorg, 40:114-118.

14. Branka F, Nikogosian H, Lobstein T, eds. The challenge of obesity in the WHO European Region and the strategies for respond. Copenhagen: WHO. 
15. Cani PD, Amar J, Iglesias MA, et al, 2007, Metabolic endotoxemia initiates obesity and insulin resistance, $R$ Diabetes, 56(7):1761-1772.

16. Cani PD, Amar J, Iglesias MA, et al, 2007, Metabolic endotoxemia initiates obesity and insulin resistance, Diabetes,56(7):1761-72

17. Cani PD, Neyrinck AM, Fava F, et al, 2007, Selective increases of bifidobacteria in gut microflora improve high-fat-diet-induced diabetes in mice through a mechanism associated with endotoxaemia, Diabet, 50 (11): 2374-2383.

18. Cani PD, Neyrinck AM, Fava F, et al, 2007, Selective increases of bifidobacteria in gut microflora improve high-fat-diet-induced diabetes in mice through a mechanism associated with endotoxaemia, Diabetologia, 50(11):2374-2383.

19. Cañete R, Gil-Campos M, Aguilera CM, et al, 2007, Development of insulin resistance and its relation to diet in the obese child, Eur J Nutr, $46 ; 181-187$

20. Collins MD, Lawson PA, Willems A, et al, 1994, The phylogeny of the genus Clostridium: proposal of five new genera and eleven new species combinations, Int J Syst Bacteriol, 44: 812-826.

21. Dalmau J, Alonso M, Gómez L, et al, 2007, Obesidad Infantil, Recomendaciones del Comité de Nutrición de la Asociación Española de Pediatria, Parte II. Diagnóstico Comorbilidades y Tratamiento, An Pediatr (Barc), 66:294-304 
22. De Graaf AA, Venema K, 2008, Gaining insight into microbial physiology in the large intestine: a special role for stable isotopes, $A d v$ Microb Physiol, 53:73-168.

23. De Palma G, 2011, Influencia de la microbiota intestinal y de cepas del género Bifidobacterium, en la enfermedad celíaca, Tesis Doctoral. Universidad Politécnica de Valencia, España

24. Delzenne NM, Cani PD, Neyrinck AM, 2007, Modulation of glucagonlike peptide 1 and energy metabolism by inulin and oligofructose: experimental data, $J$ Nutr, 137(11):2547S-2551S.

25. Dethlefsen L, Huse S, Sogin ML, et al, 2008, The pervasive effects of an antibiotic on the human gut microbiota, as revealed by deep $16 \mathrm{~S}$ rRNA sequencing, PLoS Biol, 18;6(11):e280

26. Dethlefsen L, McFall-Ngai M, Relman DA, 2007, An ecological and evolutionary perspective on human-microbe mutualism and disease, Nature, 449(7164):811-818

27. Dupont C, Rivero M, Grillon C, et al, 2010, Alpha-lactalbuminenriched and probiotic-supplemented infant formula in infants with colic: growth and gastrointestinal tolerance, Eur J Clin Nutr, 64(7):7657.

28. El-Haschimi K, Pierroz DD, Hileman SM, et al, 2000, Two defects contribute to hypothalamic leptin resistance in mice with diet-induced obesity, J Clin Invest, 105(12):1827-1832. 
29. Ferrante AW Jr, 2007, Obesity-induced inflammation: a metabolic dialogue in the language of inflammation, $J$ Intern Med, 262(4):408414

30. Gao Z, Yin J, Zhang J, et al, 2009, Butyrate improves insulin sensitivity and increases energy expenditure in mice, Diabetes, 58(7):1509-1517

31. Gómez-Ambrosi J, Salvador J, Silva C, et al, 2006, Increased cardiovascular risk markers in obesity are associated with body adiposity: role of leptin, Thromb Haemost J, 95(6):991-996

32. Gómez-Barrado JJ, Polo J, Gómez-Martino JR, et al, 2012, Juvenile obesity: what is its real prevalence in Spain?, Endocrinol Nutr. 59(2):151-152.

33. Holzapfel W, 2006, Chapter 1, Introduction to Prebiotics and Probiotics. Probiotics in Food Safty and Human Health, Taylor and Francis Group, New York, U.S.A

34. Hooper LV, MIdtvedt T, Gordon JI, 2001, Commensal host-bacterial relationships in the gut, Science, 292:1115-1118

35. Hooper LV, MIdtvedt T, Gordon JI, 2002, How host-microbiota interactions shape the nutrient environment of the mammalian intestine, Annu Rev Nutr, 22: 283-307

36. Hotamisligil GS, 2006, Inflammation and metabolic disorders, Nature, 444:860-867 
37. Hotamisligil GS, Peraldi P, Budavari A, et al, 1996, IRS-1-mediated inhibition of insulin receptor tyrosine kinase activity in TNF-alpha- and obesity-induced insulin resistance. Science, 271(5249):665-668.

38. James P T, 2011, Chapter 2 Obesity: A modern Pandemic, Obesity, Elsevier España.

39. Jansen W, Brug J, 2006, Parents often do not recognize overweight in their child, regardless of their socio-demographic background. Eur $J$ Public Health, 16:645-647.

40. Jolivet-Gougeon A, Loréal O, Ingels A, et al, 2008, Serum transferrin saturation increase is associated with decrease of antibacterial activity of serum in patients with HFE-related genetic hemochromatosis, Am J Gastroenterol, 103: 2502-2508.

41. Jubbin J, Rajesh I, 2012, Behavioral therapy for management of obesity, Indian J Endocrinol Metab, 16(1):28-32

42. Kadooka Y, Sato M, Imaizumi K, et al, 2010, Regulation of abdominal adiposity by probiotics (Lactobacillus gasseri SBT2055) in adults with obese tendencies in a randomized controlled trial, Eur $J$ Clin Nutr, 64(6):636-643

43. Klein S, Fontana L, Young VL, et al, 2004, Absence of an effect of liposuction on insulin action and risk factors for coronary heart disease, N Engl J Med, 350(25):2549-2557 
44. Konturek SJ, Konturek JW, Pawlik T, et al, 2004, Brain-gut axis and its role in the control of food intake, J Physiol Pharmacol, 55:137-154

45. Kootte RS, Vrieze A, Holleman F, et al, 2012, The therapeutic potential of manipulating gut microbiota in obesity and type 2 diabetes mellitas, Diabetes Obes Metab, 14(2):112-20

46. Kroon de ML, Renders CM, van Wouwe JP, et al, 2010, The Terneuzen birth cohort: BMI changes between 2 and 6 years correlate strongest with adult overweight. PLoS One, 5:e9155.

47. Langa S, 2006, Interacciones entre Bacterias lácticas, células del epitelio intestinal y células del sistema inmunitario, Desarrollo de un modelo in vitro. Tesis Doctoral. Facultad de Veterinaria, Universidad Complutense de Madrid

48. Larson N, Stang J, Story M, 2011, Chapter 3, Developmental origins of childhood Obesity: Potencial Public Health Impact, Obesity, Elsevier Fundación Lilly.

49. Ley RE, Bäckhed F, Turnbaugh $\mathrm{P}$, et al, 2005, Obesity alters gut microbial ecology, Proc Natl Acad Sci, 102: 11070-11075.

50. Ley RE, Turnbaugh PJ, Klein S, et al, 2006, Microbial ecology: human gut microbes associated with obesity, Nature, 444 (7122): 1022-1023

51. Li JV, Ashrafian H, Bueter M, et al, 2011, Metabolic surgery profoundly influences gut microbial-host metabolic cross talk, Gut, 60:1214-1223 
52. Macia L, Delacre M, Abboud G, et al, 2006, Impairment of dendritic cell functionality and steady-state number in obese mice, $J$ Immunol, 177(9):5997-6006.

53. Mackie RI, Sghir A, Gaskins HR, 1999, Developmental microbial ecology of the neonatal gastrointestinal tract, Am J Clin Nutr, 69(5):1035S-1045S.

54. Marschan E, Kuitunen M, Kukkonen K, et al, 2008, Probiotics in infancy induce protective immune profiles that are characteristic for chronic low-grade inflammation, Clin Exp Allergy,

55. Martínez MD, 2010, Tesis doctoral, estudio de Biomarcadores de inflamación y de riesgo cardiovascular en niños obesos prepúberes. Facultad de Medicina, Universidad de Córdoba.

56. McGovern L, Johnson J N, Paulo R, et al, 2008, Treatment of pediatric obesity: a systematic review and metaanalyses of randomized trials, $J$ Clin Endocrinol Metab, 93:4600-4605

57. Membrez M, Blancher F, Jaquet M, et al, 2008, Gut microbiota modulation with norfloxacin and ampicillin enhances glucose tolerance in mice, FASEB J, 22(7):2416-2426

58. Monereo S, Álvarez H, Moreno B, 2004, Capitulo 1: Tejido Adiposo y Obesidad. Una visión Actual. La Obesidad en el tercer milenio. 3ra Edición, SEEDO, Editorial Medica Panamericana, Madrid. 
59. Muñoz MT, 2007, Pubertad normal y sus variantes, Pediatr Integral, $11: 505-514$

60. Neish AS, Gewirz AT, Zeng H, et al, 2000, Prokaryoticregulation of epithelial responses by inhibition of IkappaB-alpha ubiquitination, Science, 289: 1560-1563

61. Oda, E, 2008 The metabolic syndrome as a concept of adipose tissue disease, Hypertens res, 431:1283-1291

62. Palmer C, Bik EM, DiGiulio DB, et al, 2007, Development of the human infant intestinal microbiota, PLoS Biol, 5(7):e177

63. Parsons TJ, Power C, Logan S, et al, 1999, Childhood predictors of adult obesity: a systematic review, Int $J$ Obes Relat Metab Disord, 23:S1-107.

64. Peuranen S, Tiihonen K, Apajalahti J, et al, 2004, Combination of polydextrose and lactitol affects microbial ecosystem and immune responses in rat gastrointestinal tract, Br J Nutr, 91: 905-914.

65. Popkin BM, 2007, The world is fat, Sci Am, 279(3):88-95

66. Pufal MA, Moulin CC, Casagrande DS, et al, 2012, Prevalence of Overweight in Children of Obese Patients: a Dietary Overview, Obes Surg, Apr 1, Epub ahead of print

67. Raj M, 2012, Obesity and Cardiovascular risk in children and adolescents, Indian J Endocrinol Metab,16(1):13-19 
68. Rector RS, Warner SO, Liu Y, et al, 2007, Exercise and diet induced weight loss improves measures of oxidatives stress and insulin sensivity in adults with characteristics of the metabolic syndrome, $A m J$ Physiol Endocrinol Metab, 293:500-506

69. Reid G, Sanders ME, Gaskins HR, et al, 2003, New scientific paradigms for probiotics and prebiotics, J Clin Gastr, 37: 105-118.

70. Reilly JJ, Kelly J, 2011, Long-term impact of overweight and obesity in childhood and adolescence on morbidity and premature mortality in adulthood: systematic review, Int J Obes (Lond), 35(7):891-898

71. Rosenbaum M, Leibel RL, 1998, The physiology of body weight regulation: relevance to the etiology of obesity in children, Pediatrics, 101:525-539

72. Säemann MD, Böhmig GA, Osterreicher CH, et al, 2000, Antiinflammatory effects of sodium butyrate on human monocytes: potent inhibition of IL-12 and up-regulation of IL-10 production, FASEB $J, 14(15): 2380-2382$

73. Samuel BS, Hansen EE, Manchester JK, et al, 2007, Genomic and metabolic adaptations of Methanobrevibacter smithii to the human gut. Proc Natl Acad Sci USA. 104(25):10643-10648

74. Sanz Y, Santacruz A, Dalmau J, 2009, Influencia de la microbiota intestinal en la obesidad y enfermedades metabólicas, Acta Ped, 1-9 
75. Sardón O, González E, Olaia Sardón, et al, 2006, El síndrome de apneas-hipopneas obstructivas durante el sueño en niños no se asocia a obesidad, Arch Bronconeumol, 42(11):583-587

76. Scarpellini E, Campanale M, Leone D, et al, 2010, Gut microbiota and obesity, Intern Emerg Med, 5 Suppl 1:S53-S56

77. Schnitzler M, Fisch P, 2012, A role for microchimerism in obesity and evolution?, Med Hypotheses, 78(4):528-532.

78. Schwartz MW, Woods SC, Porte D, 2000, Baskin DG Central nervous system control of food intake, Nature, 404(6778):661-671.

79. SEEDO, Sociedad Española para el Estudio De la Obesidad, (SEEDO), 2000, Consenso SEEDO 2000 para la evaluación del sobrepeso y la obesidad y el establecimiento de criterios de intervención terapéutica. Med Clin (Barc), 115: 587-597

80. Shine WE, Silvany R, McCulley JP, 1993, Relation of cholesterolstimulated Staphylococcus aureus growth to chronic blepharitis, Invest Ophthalmol Vis Sci, 34: 2291-2296.

81. Siebler J, Galle PR, Weber MM, 2008, The gut-liver-axis: Endotoxemia, inflammation, insulin resistance and NASH, $J$ Hepatol, 48(6): 1032-1034

82. Skilton MR, Celermajer DS, 2006, Endothelial dysfunction and arterial abnormalities in childhood obesity, Int J Obes, 30:1041-1049 
83. Speliotes Ek, Willer CJ, Berndt SI, et al, 2010, Association analyses of 429,796 individuals reveal 18 new loci associated with body mass index, Nat Genet, 42(11):937-948

84. Stappenbeck TS, Hooper LV, Gordon JI, 2002, Developmental regulation of intestinal angiogenesis by indigenous microbes via Paneth cells, Proceeding of the National Academy of Sciences of the United States of America, 99(24):15451-15455

85. Strozzi GP, Mogna L, 2008, Quantification of folic acid in human feces alter administration of Bifidobacterium probiotic strains, $J$ Clin Gastroenterol,42(3), S179-84.

86. Summerbell C, Waters E, Edmundo L, et al, 2005, Interventions for preventiving obesity in children, Cochrane Database Syst rev, (3) CD001871

87. Sweeting HN, 2007, Measurement and definitions of obesity in childhood and adolescence: a field guide for the uninitiated. Nutr $J_{2} 26$ (6):32

88. Tilg H, Moschen AR, 2006, Adipocytokines: mediators linking adipose tissue, inflammation and immunity, Nat Rev Immunol, 6: 772-783

89. Troiano RP, Flegal KM, 1998, Overweight children and adolescents: description, epidemiology, and demographics. Pediatrics, 101:497-504.

90. Turnbaugh PJ, Hamady M, Yatsunenko T, et al, 2009, A core gut microbiome in obese and lean twins, Nature, 457(7228): 480-484. 
91. Verte, 1995 Tesis de Lasaga 2010

92. Vrieze A, Holleman F, Zoetendal EG, et al, 2010, The environment within: how gut microbiota may influence metabolism and body composition, Diabetologia, 53(4):606-613

93. Wabitsch M, 2000, The acquisition of obesity: insights from cellular and genetic research, Proc Nutr Soc, 2000, 59(2):325-330

94. Waldram A, Holmes E, Wang Y, et al, 2009, Top-down systems biology modeling of host metabotype-microbiome associations in obese rodents, J Proteome Res, 8(5):2361-2375.

95. Waldram A, Holmes E, Wang Y, et al, 2009, Top-Down Systems Biology Modeling of Host Metabotype-Microbiome Associations in Obese Rodents, J Proteome Res, 8(5): 2361-2375

96. Wang Z, Nakayama T, 2010, Inflammation, A Link between obesity and Cardiovascular disease, Mediators Inflamm, doi:10.1155/2010/535918

97. Weizman Z, Alsheikh A, 2006, Safety and tolerance of a probiotic formula in early infancy comparing two probiotic agents: a pilot study, $J$ Am Coll Nutr, 25(5):415-419

98. Winkler P, Ghadim D, Schrezenmeir J, et al, 2007, Molecular and cellular basis of microflora-host interactions, $J$ Nutr, 137:756S-772S

99. Wolowczuk I, Verwaerde C, Viltart O, et al, 2008, Feeding our immune system: impact on metabolism, Clin Dev Immunol, 639803 
100. Young KM, Northern JJ, Lister KM, et al, 2007, A metanalisis of family-behavioral weight-loss treatments for children, Clin Psychol Rev, 27:240-249

101. Yuan Q, Walker A, 2004, Innate immunity of the gut: Mucosal defense in health and disease, Journal of pediatric, 38:463-473

102. Zhang H, DiBaise KJ, Zuccolo A, et al, 2009, Human gut microbiota in obesity and after gastric bypass, Proc Natl Acad Sci, 106: $2365-2370$

103. Zhang Y, Proenca R, Maffei M, et al, 1994, Positional cloning of the mouse obese gene and its human homologue, Nature, 372(6505):425-432.

104. Zhao J, Grant SF, 2011, Genetics of childhood obesity, $\underline{J \text { Obes, }}$ 1- 9

105. Zoetendal EG, Vaughan EE, de Vos WM, 2006, A microbial world within us, Mol Microbiol, 59(6):1639-1650.

106. Zoetendal EG, Ben-Amor K, Akkermans AD, et al, 2001, DNA isolation protocols affect the detection limit of PCR approaches of bacteria in samples from the human gastrointestinal tract, Syst Appl Microbiol, 24(3):405-410. 